\title{
GABRIELA AFERRI
}

\section{Exigências de energia e proteína e composição do ganho em peso compensatório de novilhos Nelore por meio do indicador óxido de deutério}

Tese apresentada à Faculdade de Zootecnia e Engenharia de Alimentos da Universidade de São Paulo, como parte dos requisitos para a obtenção do Título de Doutor em Zootecnia.

Área de Concentração: Qualidade e Produtividade Animal

Orientador: Prof. Dr. Paulo Roberto Leme 


\section{FICHA CATALOGRÁFICA}

preparada pela

Biblioteca da Faculdade de Zootecnia e Engenharia de Alimentos da Universidade de São Paulo

\begin{tabular}{|l|}
\hline A256e \\
Aferri, Gabriela \\
Exigências de energia e proteína e composição do ganho em \\
peso compensatório de novilhos Nelore por meio do indicador \\
óxido de deutério. / Gabriela Aferri - Pirassununga, 2007. \\
$90 \mathrm{f}$. \\
Tese (Doutorado) -- Faculdade de Zootecnia e Engenharia de \\
Alimentos - Universidade de São Paulo. \\
Departamento de Zootecnia \\
Área de Concentração: Qualidade e Produtividade Animal. \\
Orientador: Prof. Dr. Paulo Roberto Leme \\
Unitermos: 1. Desempenho 2. Eficiência bioeconômica \\
3. Exigências nutricionais 4. Ganho de peso compensatório \\
5. Parâmetros sangüíneos 6. Restrição alimentar. I. Título. \\
\end{tabular}




\section{AGRADECIMENTOS}

A Deus, força maior que move a vida, que esteve presente em todos os momentos da realização deste trabalho.

Ao Prof. Dr. Paulo Roberto Leme pela orientação constante.

À Faculdade de Zootecnia e Engenharia de Alimentos da Universidade de São Paulo pela oportunidade de realização do curso de doutorado.

À Prefeitura do Campus Administrativo de Pirassununga por disponibilizar os recursos físicos e humanos indispensáveis para a realização deste trabalho.

À Fundação de Amparo à Pesquisa do Estado de São Paulo pelo apoio financeiro para a realização deste trabalho.

À Coordenação de Aperfeiçoamento de Pessoal de Nível Superior pela concessão da bolsa de doutorado.

Ao Prof. Dr. Marcelo Z. Moreira pela ajuda na análise e cálculos do material com óxido de deutério.

Ao Prof. Dr. João Alberto Negrão pelos esclarecimentos e ajuda.

Às amigas Angélica S. C. Pereira e Rosana R. P. S. Corte por toda ajuda e apoio que tornaram possível a realização deste trabalho.

Ao Dr. Saulo da Luz e Silva e Me. Amaury C. Valinote pela ajuda e conhecimentos compartilhados.

Ao Me. Domingos M. C. Pesce pela otimização dos recursos disponíveis.

A todos os funcionários da FZEA, PCAPS e FMVZ que ajudaram e contribuíram nas diversas fases deste trabalho. 
À minha querida filha Júlia, Dedico este trabalho. 


\section{RESUMO}

\section{AFERRI, G. Exigências de energia e proteína e composição do ganho em peso compensatório de novilhos Nelore por meio do indicador óxido de deutério.} 2007. 98 f. Tese (Doutorado) - Faculdade de Zootecnia e Engenharia de Alimentos, Universidade de São Paulo, Pirassununga, 2007.

Foram utilizados 36 novilhos da raça Nelore, alojados em baias individuais em regime de confinamento, com 20 meses de idade e $359 \mathrm{~kg}$ no início do experimento, para determinar as exigências de energia e proteína líquidas para mantença e para ganho de peso, e também para avaliar o efeito da restrição alimentar sobre o desempenho e composição do ganho de peso, bem como o perfil hormonal dos animais e para avaliar a eficiência bioeconômica do ganho de peso compensatório em confinamento. Para isso foram realizados dois experimentos em seqüência, o primeiro teve uma duração de 58 dias e o segundo 78 dias. No primeiro foi fornecida uma mesma dieta, em três níveis de ingestão de matéria seca (MS), sendo alimentação ad libitum (TAL), 75 g MS/kg PV ${ }^{0,75}$ (T75) e 60 g MS/kg PV ${ }^{0,75}$ (T60). A composição corporal foi estimada com o óxido de deutério como marcador, que possibilitou a repetição das medidas nos mesmos animais e o estudo de suas respostas à realimentação. Os animais apresentaram exigência de energia líquida para mantença $\left(E L_{m}\right)$ de $0,070 \mathrm{Mcal} / \mathrm{kg} \mathrm{PV}^{0,75}$ e a exigência de energia líquida para ganho $\left(\mathrm{EL}_{g}\right)$ foi descrita pela equação $\mathrm{EL}_{g}=0,0467{ }^{*} \mathrm{PCVZ}^{0,75 *} \mathrm{GPCVZ}^{0,8585}$. A exigência de proteína metabolizável para mantença $\left(\mathrm{PM}_{\mathrm{m}}\right)$ foi determinada pela equação $\mathrm{PM}_{m}=4,32 * \mathrm{PV}^{0,75}$ e a exigência de proteína metabolizável para ganho $\left(P M_{g}\right)$ foi de $266 \mathrm{~g} / \mathrm{kg}$ GPCVz. No segundo experimento, os animais que receberam alimentação restrita na primeira fase foram alimentados ad libitum com a mesma dieta. Os hormônios avaliados foram influenciados pelo padrão de alimentação imposto aos animais e pelo ganho de peso compensatório. Animais que apresentaram ganho de peso compensatório apresentaram melhor eficiência bioeconômica.

Palavras-chave: desempenho; eficiência bioeconômica; exigências nutricionais; ganho de peso compensatório; parâmetros sangüíneos; restrição alimentar. 


\section{ABSTRACT}

\section{AFERRI, G. Energy and protein requirements and compensatory gain} composition of Nellore steers through the marker deuterium oxide. 2007. $98 \mathrm{f}$. Doctorate Thesis - Faculdade de Zootecnia e Engenharia de Alimentos, Universidade de São Paulo, Pirassununga, 2007.

Thirty six Nellore steers with a mean weight and age of $359 \mathrm{~kg}$ and 20 months at the beginning of the experiment were fed individually to determine the energy and protein requirements for maintenance and gain and also to evaluate the effect of the feed restriction on the performance and gain composition, hormonal profile and bio economic efficiency during re-alimentation. Two sequential experiments were developed, the first lasted 58 days and the second 78 days. In the first the steers were fed the same diet in three levels of dry matter intake, ad libitum (TAL), $75 \mathrm{~g}$ $\mathrm{DM} / \mathrm{kg} \mathrm{LW} \mathrm{LW}^{0,75}$ (T75) and $60 \mathrm{~g} \mathrm{DM} / \mathrm{kg} \mathrm{LW} \mathrm{L}^{0,75}$ (T60). The body composition was estimated with the marker deuterium oxide that allowed repeated water estimative of the same animal and the re-alimentation study. The steers had a net energy requirement for maintenance $\left(\mathrm{NE}_{\mathrm{m}}\right)$ of $0,070 \mathrm{Mcal} / \mathrm{kg} \mathrm{EBW} \mathrm{E}^{0,75}$ and the net energy requirement for gain $\left(\mathrm{NE}_{g}\right)$ was described by the equation $\mathrm{NE}_{g}=0,0467$ * $E B W^{0,75}$ * $L W G V z^{0,8585}$. The metabolizable protein requirement for maintenance $\left(\mathrm{MP}_{\mathrm{m}}\right)$ was described by the equation $\mathrm{MP}_{\mathrm{m}}=4,32{ }^{*} \mathrm{LW}^{0,75}$, and the metabolizable protein for gain $\left(\mathrm{MP}_{\mathrm{g}}\right)$ was $266 \mathrm{~g} / \mathrm{kg}$ ELWG. In the second experiment the animals that had restricted intake in the first phase were fed ad libitum. The hormones evaluated were influenced by the feeding pattern that the animals were submitted and by the compensatory weight gain. Animals that showed compensatory gain had greater bio economic efficiency.

Keywords: bio economic efficiency; blood parameters; compensatory weight gain; feed restriction; nutritional requirements; performance. 


\section{LISTA DE FIGURAS}

Figura 1 - Tempo de alimentação dos animais na fase de Restrição - Experimento I e na fase de realimentação - Experimento II

Figura 2 - Tempo de confinamento e especificação dos tratamentos usados na realimentação

Figura 3 - Média do peso vivo em jejum dos animais por tratamento no $1^{\circ}(0), 29^{\circ} \mathrm{e}$ $58^{\circ}$ dia de confinamento.

Figura 4 - Digestibilidade das dietas (\%)

Figura 5 - Concentração média dos tratamentos para IGF-I nos dias 8, 27 e 55 de confinamento.

Figura 6 - Concentração plasmática de T3 para os três períodos de colheita..........51

Figura 7 - Concentração média de T4 no tempo de confinamento.

Figura 8 - Temperatura máxima, mínima e média do dia 16 a 27 do mês de agosto de 2006

Figura 9 - Médias do peso vivo em jejum por tratamento durante os dois Experimentos .59

Figura 10 - Ingestão de matéria seca (IMS), média diária, para os tratamentos .....60

Figura 11 - Eficiência alimentar dos tratamentos nos períodos de confinamento.....61

Figura 12 - Digestibilidade da dieta para os tratamentos no Experimento II .66

Figura 13 - Digestibilidade da dieta para os tratamentos no Experimento I e II (E1 e E2).

Figura 14 - Concentração plasmática de IGF-I dos tratamentos, considerando os dois Experimentos.

Figura 15 - Concentrações médias dos tratamentos para T3. 69

Figura 16 - Concentração de T3 dos tratamentos, considerando os dois Experimentos .

Figura 17 - Concentração de T4 dos tratamentos, considerando os dois Experimentos ....

Figura 18 - Concentração de glicose ao longo dos dois experimentos .72

Figura 19 - Valores médios da concentração de proteína total nos Experimentos I e

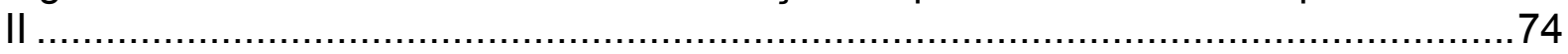

Figura 20 - Concentração de NUP para os tratamentos nos dois Experimentos......75

Figura 21 - Projeção das curvas de ganho de peso vivo para os tratamentos em compensação atingirem o peso do tratamento TAL 


\section{LISTA DE TABELAS}

Tabela 1 - Composição da dieta fornecida aos animais com base na matéria seca 23

Tabela 2 - Composição bromatológica (\%) da silagem de sorgo, do concentrado e da dieta

Tabela 3 - Composição bromatológica da silagem de milho, do concentrado e da dieta expressos em \% da matéria seca.

Tabela 4 - Valores médios, mínimos e máximos de D2O injetado (QI) e no sangue nos tempos zero (EDT0) e 6-8 horas após (EDT6-8) e quantidade de água (QA), nas três datas de avaliação

Tabela 5 - Peso em jejum, peso do corpo vazio e composição percentual do corpo vazio

Tabela 6 - Composição química do corpo vazio inicial e final

Tabela 7 - Taxa de deposição dos componentes químicos corporais e composição do ganho de peso vazio

Tabela 8 - Valores mínimos e máximos para taxa de deposição dos componentes químicos corporais e composição do ganho de peso vazio

Tabela 9 - Valores da relação peso de corpo vazio : peso vivo (PCVZ:PVj) e ganho de peso vazio : ganho de peso vivo (GPCVZ:GPVj)

Tabela 10 - Exigência diária de energia líquida (Mcal) para mantença e para diferentes taxas de ganho diário de peso de corpo vazio $(\mathrm{kg} / \mathrm{dia})$ em função do peso vivo em jejum ou peso do corpo vazio (PCVZ)

Tabela 11 - Concentração de energia (Mcal/kg) depositada no corpo vazio e no ganho de um quilo em peso de corpo vazio

Tabela 12 - Exigências de proteína líquida e metabolizável por quilo de peso de corpo vazio (kg PCVZ) e por quilo de ganho de peso de corpo vazio (GPCVZ) ......46

Tabela 13 - Exigência de proteína metabolizável (g/dia) para mantença segundo o valor encontrado por Wilkerson et al. (1993), Valadares Filho et al. (2006) e deste experimento - Aferri (2007).

Tabela 14 - Médias dos tratamentos para concentração plasmática de glicose

Tabela 15 - Médias dos tratamentos e dos tempos de confinamento para a concentração de proteína total 
Tabela 17 - Médias do peso vivo em jejum dos tratamentos por tempo de realimentação, valor de $\mathrm{P}$ e equações dos efeitos de tratamento e tempo .58

Tabela 18 - Equações e valores de $\mathrm{P}$ para os efeitos de tratamento e tempo dos dados de eficiência alimentar....

Tabela 19 - Período de confinamento, peso em jejum inicial e final, peso do corpo vazio inicial e final e espessura de gordura subcutânea (EGS)

Tabela 20 - Composição percentual do corpo vazio inicial e final, determinadas pelo espaço de deutério.

Tabela 21 - Composição química do corpo vazio inicial e final 64

Tabela 22 - Taxa de deposição dos componentes químicos corporais no corpo vazio e composição do ganho de peso vazio

Tabela 23 - Valores médios de NUP para tempo e tratamento 75

Tabela 24 - Médias de peso vivo final, peso de carcaça quente (CQ), rendimento de carcaça quente, peso do fígado e gordura pélvica renal e inguinal (PRI) .

Tabela 25 - Custos com matéria seca ingerida (MSI) e reais gastos por quilo de ganho de peso vivo ( $\mathrm{R} \$ / \mathrm{kg}$ GPV) e por quilo de carcaça ganho .78 


\section{LISTA DE ABREVIATURAS}

AGD - ácido graxo digestível

CNFD - carboidrato não fibroso digestível

$\mathrm{CNFD}_{\mathrm{u}}$ - carboidrato não fibroso digestível para alimento com uréia

$\mathrm{CQ}$ - carcaça quente

$\mathrm{CVZ}$ - corpo vazio

$\mathrm{D}_{2} \mathrm{O}$ - óxido de deutério

$\mathrm{dL}-$ decilitro

DMS - digestibilidade da matéria seca

EA - eficiência alimentar

EB - energia bruta

ED - energia digestível

EDT - espaço de deutério

EE - extrato etéreo

$\mathrm{EL}$ - energia líquida

$\mathrm{EL}_{g}$ - energia líquida para ganho

$E \mathrm{~L}_{\mathrm{m}}$ - energia líquida de mantença

EM - energia metabolizável

ER - energia retida

FDA - fibra em detergente ácido

$\mathrm{FDA}_{i}$ - fibra em detergente ácido indigestível

FDA $A_{i} A l i$ - fibra em detergente ácido indigestível no alimento

$\mathrm{FDA}_{\mathrm{i}} \mathrm{Fez}$ - fibra em detergente ácido indigestível nas fezes

FDN - fibra em detergente neutro

$\mathrm{FDN}_{\mathrm{cp}}$ - fibra em detergente neutro corrigida para cinzas e proteína

$F D N_{c p} D$ - fibra em detergente neutro corrigida para cinzas e proteína digestível

g-grama

GC - ganho de carcaça

GH - hormônio do crescimento

GMD - ganho médio diário

GPCVZ - ganho de peso de corpo vazio

GPV - ganho de peso vivo

$\mathrm{GPV}_{\mathrm{j}}$ - ganho de peso vivo em jejum 
$\mathrm{HH}$ - Hankins e Howe, seção da $9^{\circ}-10^{\circ}-11^{\circ}$ costelas

IEM - ingestão de energia metabolizável

IGF-I - fator de crescimento semelhante à insulina

kcal - quilocaloria

$\mathrm{kg}$ - quilograma

$k_{g}$ - eficiência de uso da EM para ganho em peso

$\mathrm{L}-$ litro

Log - logaritmo

Mcal - megacaloria

mg - miligrama

$\mathrm{ml}$ - mililitro

MM - matéria mineral

MO - matéria orgânica

MS - matéria seca

$\mathrm{MSI}$ - matéria seca ingerida

$\mathrm{N}$ - nitrogênio

NDT - nutrientes digestíveis totais

ng - nanograma

NUP - nitrogênio uréico no plasma

NUS - nitrogênio uréico no sangue

${ }^{\circ} \mathrm{C}$ - graus Celsius

PB - proteína bruta

PBD - proteína bruta digestível

$\mathrm{PBD}_{\mathrm{c}}$ - proteína bruta digestível para concentrado

$\mathrm{PBD}_{v}$ - proteína bruta digestível para volumoso

$\mathrm{PC}$ - produção de calor

PCVZ - peso do corpo vazio

$\mathrm{PCVZ}^{0,75}$ - peso do corpo vazio metabólico

PDR - proteína degradável no rúmen

PIDA - proteína ligada ao detergente ácido

$\mathrm{PL}_{g}$ - proteína líquida para ganho

PMic - proteína microbiana

PNDR - proteína não degradável no rúmen

$P R I$ - pélvica, renal e inguinal

PT - proteína total 
$\mathrm{PV}$ - peso vivo

$\mathrm{PV}^{0,75}$ - peso vivo metabólico

$\mathrm{PV}_{\mathrm{j}}$ - peso vivo em jejum

T3 - triiodotironina

T4 - tiroxina

TGI - tratogastrintestinal 


\section{SUMÁRIO}

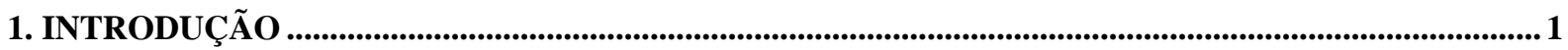

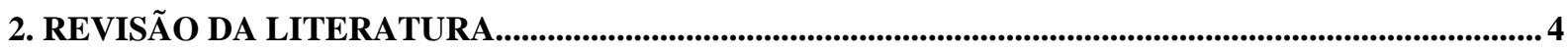

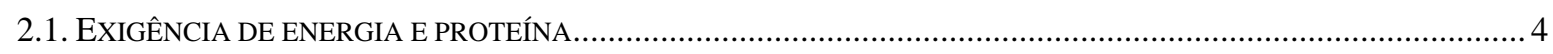

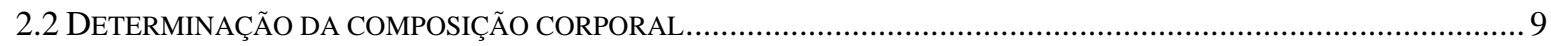

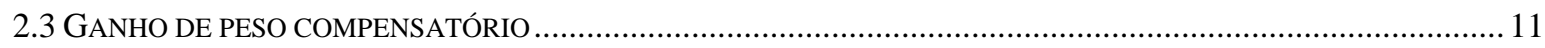

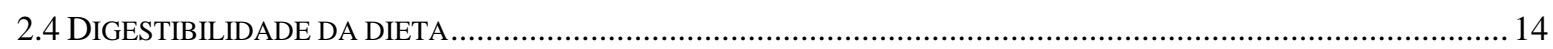

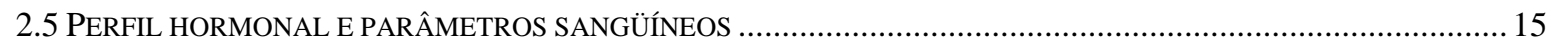

3. OBJETIVOS

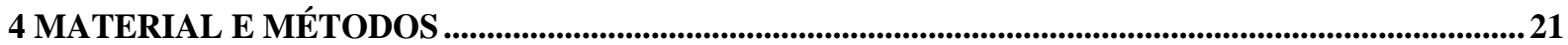

4.1 EXPERIMENTO I - EXIGÊNCIAS NUTRICIONAIS (RESTRIÇÃO) ...........................................................22

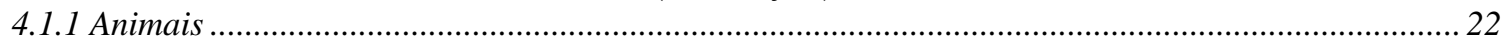

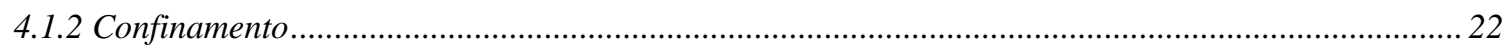

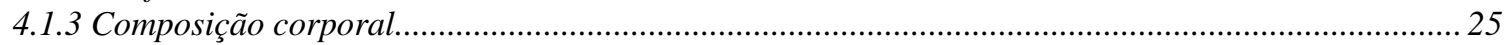

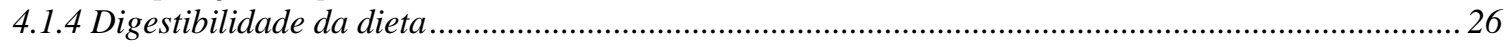

4.1.5 Determinação das exigências de energia e proteína ......................................................................27

4.1.6 Perfil hormonal e parâmetros sangüíneos ......................................................................................... 29

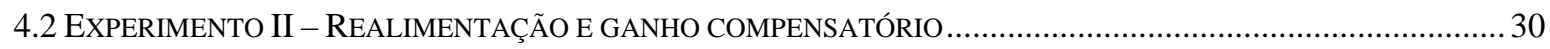

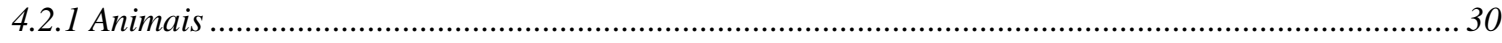

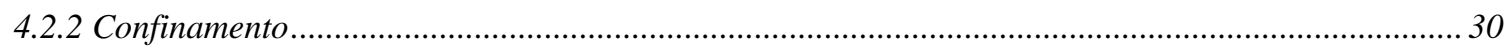

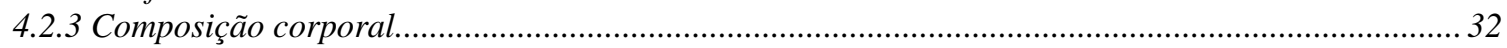

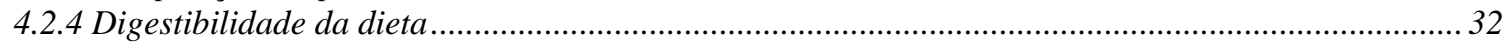

4.2.5 Perfil hormonal e parâmetros sanguíneos .................................................................................. 32

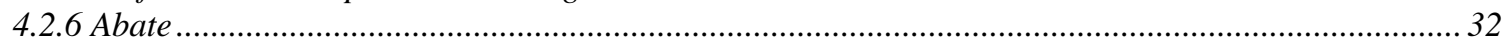

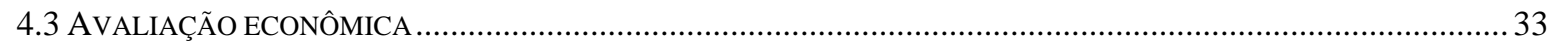

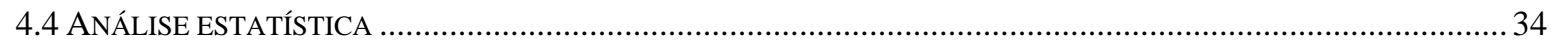

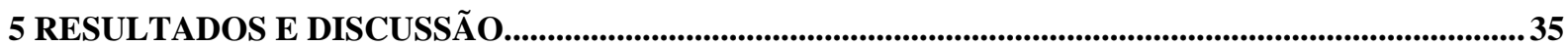

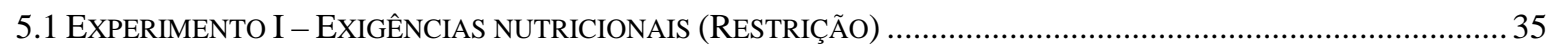

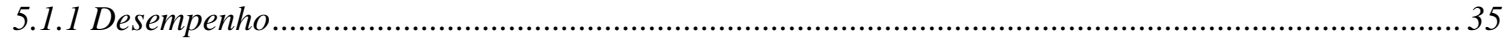

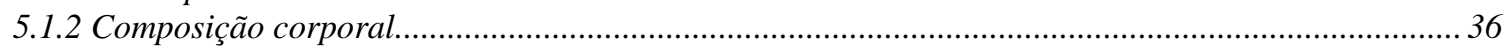

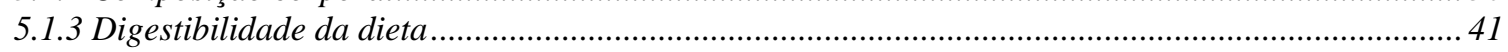

5.1.4 Determinação das exigências de energia e proteína ..................................................................... 42

5.1.5 Perfil hormonal e parâmetros sanguíneos ...................................................................................... 49

5.2 EXPERIMENTO II - REALIMENTAÇÃO E GANHO COMPENSATÓRIO..............................................................5

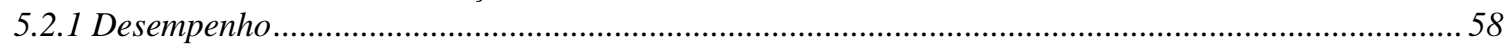

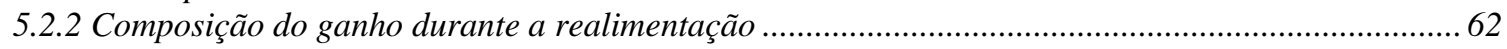

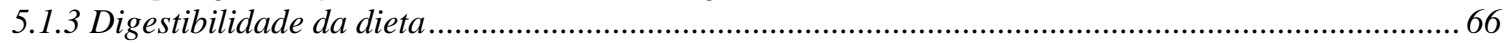

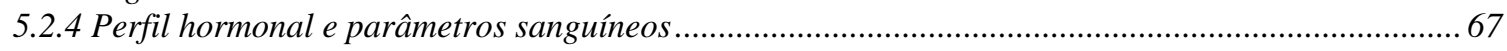

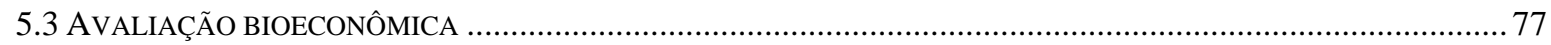

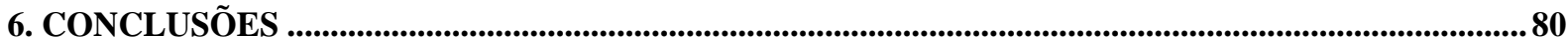

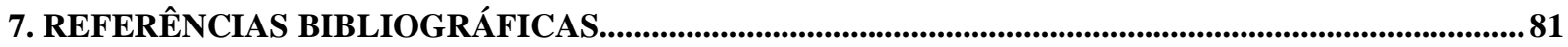




\section{Introdução}

A vida animal depende da ingestão de alimentos para fornecer a energia e os nutrientes necessários para o crescimento, mantença de tecidos, combate aos parasitos, doenças (McFARLAND, 1999) e para as funções produtivas.

A forma como a energia para a mantença da vida é usada tem sido alvo de pesquisa há muito tempo. Webster (1983) relatou que o início do estudo sobre energia foi publicado por Lavoisier e de la Place em 1784 e cita ainda outros pesquisadores que desenvolveram trabalhos sobre metabolismo energético, como Kellner (1900), Rubner (1902), Brody (1945), Kleiber (1961) e Blaxter (1962), cujos estudos contribuíram para o desenvolvimento do sistema de uso da energia como é conhecido atualmente.

Atualmente na nutrição animal a energia bruta $(E B)$ do alimento é fracionada em energia digestível (ED), energia metabolizável (EM) e energia líquida (EL). No início de 1963, Lofgreen e Garret (1968) estabeleceram o sistema de energia líquida para uso na fase de crescimento e engorda de gado de corte. Neste sistema, os requerimentos de mantença $\left(E L_{m}\right)$ e de ganho de peso $\left(E L_{g}\right)$ do animal foram separados e o valor de energia líquida dos alimentos para estas duas funções estimados (LOFGREEN and GARRET, 1968). Esta proposta denominada Sistema de Energia Líquida da Califórnia foi adotada pelo National Research Council a partir de 1976 (NRC, 1996) e baseou-se no método de abate comparativo para estimar as necessidades nutricionais dos animais para mantença e produção.

Segundo Williams e Jenkins (2003), o modelo de utilização da energia metabolizável pode ser empregado no sistema de produção de gado de corte como ferramenta de gestão, onde é possível prever o impacto das decisões nutricionais na produtividade.

O sistema de EL apresenta vantagens fundamentais ao estabelecer os requerimentos dos animais de forma independente da dieta e de estimar, separadamente, o valor dos alimentos para as diferentes funções fisiológicas (mantença, ganho de peso, lactação e gestação), através de coeficientes específicos de eficiência de utilização da energia para as diferentes funções (FONTES et al., 2005a). Outra questão a ser considerada na determinação da exigência de energia é que, segundo Fiems et al. (2007), os animais podem usar de modo mais eficiente a energia presente nos alimentos quando estão em período de restrição alimentar. 
O sistema de EL foi estabelecido com animais de raças britânicas, principalmente a Hereford, confinados a partir da desmama. Entretanto, no Brasil predominam raças zebuínas, principalmente a Nelore, confinadas em geral com mais de dois anos, e as estimativas de exigências para esses animais ainda são relativamente pequenas.

Uma estratégia comum na produção de gado de corte no Brasil, segundo Gomes Júnior et al. (2002), é fazer a estação de monta de janeiro a março, concentrando os nascimentos de outubro a dezembro, início do período de chuvas e, portanto, com maior disponibilidade e qualidade das forrageiras. Assim, os bezerros são desmamados de maio a julho, época em que a maioria das pastagens tem quantidade e qualidade reduzidas, sendo justamente neste período que se inicia a recria.

Sales et al. (2004) consideraram que animais em recria devem apresentar ganho de peso moderado, visando proporcionar o desenvolvimento do esqueleto e da musculatura e aproveitar o crescimento compensatório que ocorre com o retorno das boas condições de pastagens na época chuvosa. Segundo Vaz et al. (2004), os sistemas de produção em que os animais são abatidos aos dois anos de idade são boas alternativas, por não demandarem maiores volumes de recursos e oferecerem ao consumidor carne de boa qualidade.

Acedo et al. (2003), citando Vilares (1984), comentaram que na pecuária de corte a eficiência produtiva na fase de recria tem um grande peso no sucesso da atividade, visto que essa categoria reúne o maior contingente populacional do rebanho (48\%), além de reter os animais no sistema por longo período, abrangendo $58 \%$ do ciclo produtivo.

Considerando este aspecto, Manella (2003) ressaltou que o desafio da pecuária de corte nos trópicos é produzir de forma eficiente carne bovina de boa qualidade a baixo preço reduzindo a idade de abate para 24 meses. Na tentativa de melhorar a eficiência de sistemas de alimentação durante os períodos críticos, como alternativa de redução da idade de abate de animais recriados em pastagens, Euclides et al. (1998) concluíram que a suplementação alimentar combinada ou não com confinamento, mostrou-se uma atividade economicamente viável. Outros autores também encontraram viabilidade na suplementação de bovinos na recria para chegar ao peso de confinamento na segunda seca (BRITO, 2004; MANELLA et al., 2002; PAULINO et al., 2004a; TOMICH et al., 2003). 
Sainz et al. (1995), referindo-se ao sistema de produção americano, observaram que animais que passaram por período de estresse alimentar tiveram seus preços aumentados quando comercializados para o confinamento, pela expectativa dos benefícios do ganho compensatório.

Estudando produção de gado de corte em sistemas baseados em pastagem envolvendo, portanto, o ganho de peso compensatório, Tolla et al. (2003) consideraram importante saber qual a idade e com qual freqüência os animais poderiam ser submetidos a taxas moderadas de crescimento sem diminuir sua capacidade de responder a níveis melhores de alimentação, pois os animais submetidos a níveis severos de restrição, abaixo da mantença, não conseguiram expressar o mesmo desempenho que animais alimentados à vontade.

No sistema de produção brasileiro, em geral, os animais exibem ganho de peso compensatório de moderado a intenso quando confinados na segunda seca de vida, após um período de deficiência nutricional em pastejo. No presente estudo procurou-se estimar a composição do ganho de peso de animais após a restrição alimentar, bem como estimar as exigências nutricionais de novilhos da raça Nelore. 


\section{Revisão da literatura}

\subsection{Exigência de energia e proteína}

A energia líquida constitui a fração da energia ingerida disponível para o animal que pode ser utilizada para atividades de mantença e produção (crescimento corporal, reprodução e produção de leite). A quantidade de energia líquida (EL) disponível para mantença e produção, bem como a quantidade de energia dissipada na forma de calor, depende da energia metabolizável (EM) dos alimentos (FREITAS et al., 2006c).

Pela definição de energia líquida para mantença $\left(E L_{m}\right)$ proposta por Lofgreen e Garret (1968) a ELm é o ponto onde a quantidade de alimento ingerido necessário para manter o equilíbrio de energia é igual à produção de calor do animal em jejum. A produção de calor é calculada como a ingestão de energia metabolizável menos a energia retida pelo animal, onde a energia metabolizável é a energia bruta menos a energia das fezes, da urina e perdida na forma de gases. A energia retida, ou energia depositada no ganho é determinada pelo método de abate comparativo e é a exigência de energia líquida para ganho de peso.

Outra forma de definir a exigência de energia para mantença é a necessidade de ingestão de energia onde o animal mantém seu peso, incluindo a regulação da temperatura corporal, os processos metabólicos essenciais e a atividade física (NRC, 1996). Segundo o NRC (1996) a exigência de $E L_{m}$ para gado de corte é estimada em $77 \mathrm{kcal} / \mathrm{PV}^{0,75}$. A partir do fornecimento da $E L_{m}$ pode-se estimar quanto de energia será necessário para crescimento, produção de carne e deposição de gordura nos bovinos de corte, ou seja, qual a energia líquida $\left(E L_{g}\right)$ disponível ou necessária para determinada expectativa de ganho de peso.

Para Valadares Filho et al. (2005) as exigências líquidas de energia para mantença são representadas pela energia despendida no metabolismo basal e pelo calor produzido pelas atividades voluntárias do animal e correspondem, numa situação de consumo zero, à produção de calor. Entretanto, em condições práticas, torna-se impossível manter animais em condição de consumo zero. Desta forma, o calor produzido por animais mantidos em diferentes níveis de consumo energético pode ser medido, permitindo estimar a produção de calor no consumo zero de 
energia metabolizável por extrapolação. Geay (1984) também cita a alimentação de animais de grupos homogêneos fornecida em níveis diferentes de ingestão de energia como a melhor maneira de determinar as exigências nutricionais dos animais.

A técnica para obtenção das exigências líquidas dos nutrientes parece estar bem estabelecida, afirmaram Valadares Filho et al. (2005) em ampla revisão sobre o assunto. O conhecimento preciso da composição corporal e das exigências de energia e proteína para ganho de peso dos animais, bem como do valor nutricional dos alimentos, é fundamental para o balanceamento de dietas, de forma a permitir melhor aproveitamento do potencial genético dos animais, de maneira economicamente viável (FREITAS et al., 2006b). Sendo assim, de posse da composição corporal, calculam-se as exigências líquidas dos nutrientes para ganho de peso de corpo vazio (PCVZ), que podem ser convertidas em ganho de peso vivo (PV) a partir da relação entre o PCVZ e o PV (VALADARES FILHO et al., 2005).

Segundo o NRC (1996), as exigências de energia variam segundo o peso do animal, raça, sexo, idade, ambiente, estado fisiológico e nutrição prévia. Para o gado Bos indicus o NRC 2000 sugere que a exigência de $E L_{m}$ deve ser 10\% menor. Embora não tenha sido devidamente mensurado em animais Nelore, é sugerido um incremento de $15 \%$ nas exigências de energia metabolizável para mantença a cada múltiplo da energia metabolizável consumida acima do consumo necessário para a produção de calor em jejum, ou seja, para cada múltiplo de consumo em relação às exigências líquidas de energia para mantença (VALADARES FILHO et al., 2005).

Segundo Berndt (2000), a eficiência de crescimento de animais de corte é dependente de duas características básicas: a taxa de ganho e a composição química dos tecidos depositados. Quanto maior a taxa de ganho, maior a eficiência de conversão em função da diluição das exigências de mantença, que podem variar em função do peso, raça, sexo, idade, estação do ano, temperatura, estado fisiológico e nutrição prévia (NRC, 1996). A eficiência energética para síntese de proteína e tecido adiposo determina boa parte da variação na eficiência líquida de utilização da energia. A síntese de gordura é energeticamente mais eficiente (60 a $80 \%$ ) que a de proteína (10 a 40\%) (FREITAS et al., 2006c).

Em trabalho com animais zebuínos em crescimento, Boin e Moura (1977) verificaram exigência de energia inferior às recomendações encontradas nas publicações do ARC e NRC. Os autores consideraram que essa menor exigência 
dos zebuínos pode ser devida a menor demanda para a mantença desses animais e/ou uma acumulação menor de tecido gorduroso por unidade de ganho.

Sobre as diferenças nas exigências de mantença entre raças, Fontes et al. (2005b) citaram que parte destas deve-se a variações nos tamanhos relativos dos tecidos ou órgãos do corpo e a fatores como reciclagem da proteína corporal, que é maior em animais de raças com maior massa muscular e em animais não-castrados, em relação a machos castrados e a fêmeas. A atividade metabólica da proteína corporal é muito mais intensa que a do tecido adiposo, o que tende a elevar as exigências de energia de mantença, por unidade de tamanho metabólico, em animais com maiores proporções de músculos ou de menor maturidade fisiológica (GARRET, 1980).

Ainda sobre as diferenças entre raças, Tolla et al. (2003) citaram que animais com maturidade mais lenta respondem melhor, em termos de ganho de peso compensatório depois de um período de restrição alimentar, que animais de maturação mais rápida.

A menor exigência de energia líquida de mantença para animais Nelore pode ser atribuída à menor massa dos órgãos internos e menor reciclagem de proteína destes animais em relação às raças taurinas (CHIZZOTTI et al., 2006).

Os dados dos trabalhos de exigência de energia líquida para mantença para a raça Nelore realizados no Brasil são divergentes. Silva et al. (2002a) utilizaram parcial ou totalmente dados de 14 artigos para determinação de exigências nutricionais e encontraram o valor médio para $E L_{m}$ de 71,30 $\pm 12,69 \mathrm{kcal} / \mathrm{PCVZ}^{0,75}$ para animais Nelore, sendo este valor $7,4 \%$ menor que a exigência dos taurinos.

Dados semelhantes foram encontrados por Calegare (2004) para vacas Nelore em lactação, que apresentaram exigência diária de mantença $6 \%$ menor que vacas cruzadas Simental x Nelore, mas a exigência de mantença por unidade de peso metabólico não diferiu entre os grupos avaliados. Segundo a autora, uma vez que os animais cruzados eram meio-sangue Nelore, as diferenças de $6 \%$ são bastante semelhantes às sugeridas pelo NRC (1996), de cerca de 10\% para zebuínos em relação aos taurinos. Por outro lado, Tedeschi et al. (2002) não encontraram diferenças na exigência de tourinhos ou novilhos castrados Nelore para o preconizado para taurinos, com valores de 77,2 e $77 \mathrm{kcal} / \mathrm{PCVZ}^{0,75}$.

Os dados de exigência de energia líquida para ganho também são variáveis. Considerando trabalhos brasileiros que determinaram estas necessidades para 
animais em diferentes pesos vivos, mas com a mesma taxa de ganho de um quilograma ao dia, observou-se que para $300 \mathrm{~kg}$ de PV os dados variaram de 3,51 até 5,74 Mcal/GPCVZ, sendo a recomendação do NRC (1996) de 4,00 Mcal/GPCVZ. Para animais de $400 \mathrm{~kg}$ de PV a variação foi de 3,92 até 9,02 Mcal/kg GPCVZ, enquanto o NRC (1996) sugere 4,96 Mcal/kg GPCVZ (BOIN, 1995; FONTES, 1995; SILVA et al., 2002a). Para o peso de 200 kg, Boin (1995) e Fontes (1995) encontraram dados semelhantes de 3,03 e 3,21 Mcal/kg GPCVZ, diferente do valor encontrado por Putrino (2002) de 2,59 Mcal/kg GPCVZ.

Em trabalho com bovinos Nelore, puros e cruzados, Freitas et al. (2006a) observaram que os dois grupos utilizaram a energia para mantença e crescimento com a mesma eficiência. $E$ ainda, a redução nas exigências de EM para ganho, por unidade de peso do corpo vazio, em função do peso corporal, indica maior eficiência de utilização da EM com a elevação do peso.

Juntamente com a exigência de energia, devem ser consideradas as necessidades de proteína para mantença e crescimento. Segundo o NRC (1996), a relação entre energia e proteína pode ser expressa pela proporção entre energia da dieta e produção de proteína bruta microbiana, sendo a eficiência de síntese de proteína bruta microbiana estimada em $13 \%$ dos nutrientes digestíveis totais (NDT) presente na dieta. Desta forma, a necessidade de proteína é estabelecida em função da taxa de ingestão de energia e do conseqüente ganho de peso.

Oliveira Junior et al. (2004) citaram que o modelo de proteína metabolizável proposto pelo NRC 1996 divide as estimativas das exigências protéicas em proteína degradável no rúmen (PDR), que deve suprir as exigências dos microrganismos ruminais e proteína não degradável no rúmen (PNDR), que deve complementar a proteína microbiana que chega ao abomaso. Isso foi um avanço, pois se sabe que é de fundamental importância a síntese de proteína microbiana e, para que esta ocorra, é necessário que se tenha PDR, em quantidade e qualidade a fim de se atingir a máxima eficiência. Para dietas com alto teor de concentrado, Shain et al. (1998) observaram que pode haver deficiência na PDR, se não houver inclusão de uma fonte de proteína prontamente disponível. Isso pode reduzir o crescimento bacteriano e piorar a digestão ruminal com subseqüente diminuição no ganho animal e na eficiência alimentar.

Segundo Lima et al. (2004), através da fermentação ruminal da fração da proteína degradável no rúmen é produzida amônia, utilizada na síntese de proteína 
microbiana. Parte desta amônia, produzida no rúmen, escapa da incorporação pelos microrganismos, sendo absorvida e, no fígado, é convertida em uréia. A quantidade de amônia produzida e a que escapa da conversão para uréia refletem diretamente a quantidade de proteína degradável no rúmen e a disponibilidade de carboidratos passíveis de fermentação para suportar o crescimento dos microrganismos e a síntese protéica.

Em dieta com elevada proporção de concentrado e baixa proteína a disponibilidade de nitrogênio para crescimento microbiano pode limitar a síntese de proteína microbiana e a digestão de nutrientes, segundo Devant et al. (2001). A degradabilidade da proteína bruta do farelo de soja diminuiu em dieta de com elevada proporção de concentrado limitando a disponibilidade de $\mathrm{N}$-amino microbiano, amônia e ácidos graxos voláteis. Nestas dietas, a presença de nitrogênio prontamente disponível pode melhorar a síntese de proteína microbiana, e a presença de $\mathrm{N}$-amino e a concentração ruminal de $\mathrm{N}-\mathrm{NH} 3$ podem melhorar a digestão dos nutrientes (DEVANT et al., 2001).

Avaliando níveis de proteína bruta (PB) na dieta de zebuínos, Obeid et al. (2006) encontraram o melhor resultado para o nível de $12 \%$ de PB na matéria seca (MS). A ingestão diária mínima de proteína degradada no rúmen foi de 0,684 kg para maior ganho de peso e menor custo de produção sem comprometer a digestibilidade aparente total da maioria dos nutrientes.

Os dados brasileiros sobre exigência de proteína líquida para Nelore são divergentes. Boin (1995) encontrou valores de 181 e 180 g/kg PCVZ para novilhos com peso vivo variando de 350 a $450 \mathrm{~kg}$. Dados descritos por Fontes (1995) foram de 158 e $150 \mathrm{~g} / \mathrm{kg}$ PCVZ para os mesmos PV.

Considerando o ganho de peso de um quilograma ao dia para a raça Nelore, Silva et al. (2002b) encontraram valores de exigência de proteína de 177,60 e $173,72 \mathrm{~g} / \mathrm{kg}$ GPCVZ para animais inteiros com PV de 300 e $400 \mathrm{~kg}$, respectivamente. Enquanto Freitas et al. (2006b) observaram exigência líquida de proteína de 146,0 g para bovinos Nelore e mestiços com $400 \mathrm{~kg}$ de peso vivo. Segundo trabalho de Putrino et al. (2006) os animais da raça Nelore apresentaram maior exigência líquida de proteína para ganho (188 g/kg GPCVz) que animais Brangus. 


\subsection{Determinação da composição corporal}

A determinação da composição corporal de bovinos é essencial em estudos de nutrição para avaliar alimentos e o crescimento animal. Pela composição corporal é possível identificar alterações na composição do crescimento, em função de diversos fatores como raça, peso, sexo, e composição da dieta, e ainda, determinar a eficiência e as exigências nutricionais de diferentes categorias de animais, bem como avaliar o efeito de qualquer composto modificador do metabolismo (Henrique et al., 2003).

O primeiro passo para a determinação das exigências nutricionais de bovinos consiste em mensurar a composição corporal dos animais. A composição química do corpo do animal em momentos distintos permite conhecer a energia retida (ER) pelo ganho de peso e conseqüentemente a $E L_{g}$. $O$ método de determinação de exigências nutricionais proposto por Lofgreen e Garret (1968) foi baseado na técnica do abate comparativo para determinação da energia retida no corpo de animais alimentados em diferentes níveis de ingestão de nutrientes.

Outra informação necessária para os métodos de determinação da energia retida pelo animal é o conhecimento do peso do corpo vazio e sua constituição. Segundo O'Donovan (1984) este peso é encontrado pela diferença entre o peso vivo do animal e o conteúdo do trato gastrintestinal e urina, e ainda, pode-se encontrar grande variação nesta medida em função do tipo de dieta à qual os animais são submetidos.

Os métodos utilizados para predição da composição corporal e/ou da carcaça são classificados em diretos ou indiretos (PAULINO et al., 2006). A determinação da composição química corporal e do ganho de peso deveria ser feita por intermédio da análise química do corpo vazio do animal. Entretanto, há necessidade de moagem de todos os tecidos, o que, além de trabalhoso, apresenta custo elevado (LEME et al., 2000). Os métodos diretos consistem na separação e dissecação de todas as partes do corpo dos animais, e subseqüente determinação dos constituintes físicos e químicos (PAULINO et al., 2006). Já os métodos indiretos envolvem a predição da composição, tanto do corpo, quanto das carcaças dos animais, a partir de parâmetros mais facilmente obtidos.

Os métodos indiretos mais difundidos são as técnicas da análise da seção $\mathrm{HH}$, determinada por Hankins e Howe, e da gravidade específica usada por Lofgreen 
e Garret (1968), que possuem como limitação a impossibilidade de repetir a medida no mesmo animal.

Isso levou à procura de métodos indiretos não destrutivos, que permitissem a obtenção da composição do mesmo animal repetidas vezes (LEME et al., 1994), como a técnica indireta da diluição de isótopos, neste caso o deutério, também usada por Lanna et al. (1998). O uso de água marcada com deutério, segundo Scagliusi e Lancha Júnior (1995) é um método de boa acurácia e de usos variados, sendo empregado em estudos de nutrição humana desde 1949.

Segundo Jorge et al. (2000), as informações disponíveis no Brasil sobre a composição química corporal, de diferentes raças e em diversas maturidades fisiológicas, são ainda limitadas, em virtude de sua determinação ser trabalhosa e de alto custo.

Os componentes químicos do corpo (água, proteína, gordura e elementos minerais) variam, durante o crescimento, de forma paralela à composição física (tecidos muscular, ósseo e adiposo), e ambos são influenciados por diversos fatores como idade, peso, raça, condição sexual e nível nutricional dos animais com reflexos nos custos de produção e na qualidade da carne. Portanto, é fundamental que métodos rápidos e econômicos para estimativa da composição física e química da carcaça e/ou do corpo do animal sejam disponíveis (VÉRAS et al., 2001a).

Considerando os dados de composição obtidos por diversos autores, Reid et al. (1995) concluíram que entre os principais componentes do corpo animal a gordura e a água foram variáveis, mas a proteína e os minerais na matéria seca sem gordura foram praticamente constantes. Reid et al. (1963), analizando dados obtidos na Universidade de Cornell, bem como dados de diversos autores, confirmaram a constância das porcentagens de proteína e cinzas na matéria seca desengordurada. A relação entre água e gordura em bovinos não foi afetada pela idade, tipo de animal (corte ou leite) e sexo. Confirmaram também a premissa de que a composição do corpo vazio livre de gordura era constante, especialmente nos animais que atingiram a maturidade química. Após 400 dias de idade aproximadamente, as mudanças na composição corporal foram pequenas, sendo que os bovinos apresentaram valores de $80,3 \pm 1,7 \%$ de proteína e $19,7 \pm 1,7 \%$ de cinzas.

Após o nascimento, os bovinos iniciam uma fase de crescimento que pode ser representada por uma curva do tipo sigmóide, que possui inclinação crescente do 
nascimento à puberdade e, a partir deste estádio, apresenta uma fase de desaceleração do crescimento, caracterizada pelo aumento na taxa de deposição de gordura e pela diminuição na taxa de deposição de proteína. Esse comportamento é acompanhado pelo aumento nas exigências de energia e redução nas de proteína para ganho de peso com a elevação do peso do animal (FREITAS et al., 2006b).

Na primeira fase, o crescimento é acelerado, em razão do desenvolvimento dos tecidos ósseo e muscular, ativado pela liberação dos hormônios protéicos de crescimento tiroxina e somatotropina, ocorrendo maior síntese de tecido muscular em relação ao adiposo (FREITAS et al., 2006b).

A taxa de deposição de proteína depende da idade e do peso adulto e aumenta, à medida que a taxa de ganho de peso vazio se eleva, enquanto os animais estão em crescimento. Esta deposição protéica decresce a zero, quando o animal atinge seu peso adulto, embora ainda continue a depositar gordura (OWENS et al., 1993).

Avaliando o desenvolvimento de bovinos Nelore a partir de $286 \mathrm{~kg}$ de peso vivo Freitas et al. (2006a) observaram que o aumento no conteúdo corporal de gordura foi bem mais pronunciado que o de proteína, principalmente a partir de 300 $\mathrm{kg}$ de peso corporal vazio.

\subsection{Ganho de peso compensatório}

O elevado custo da alimentação na produção de gado de corte, segundo Nkrumah et al. (2006), faz com que a lucratividade dependa de um eficiente e produtivo uso do alimento para mantença e crescimento, com mínimas perdas ou excessos. No entanto, em condições normais de produção de bovinos de corte no Brasil, geralmente o crescimento dos animais não é linear, devido às variações sazonais na quantidade e qualidade da forragem disponível.

Em diversos estudos foi verificado que animais mantendo ou perdendo peso por um período considerável de tempo apresentam diminuição na exigência de alimentos ou nutrientes, acompanhados em certos casos por redução na taxa de metabolismo basal (O'DONOVAN, 1984).

Quando um animal passa por um período de crescimento limitado e depois recebe uma dieta de alta qualidade à vontade, freqüentemente responde com 
aumento na taxa de crescimento e na eficiência alimentar, ou seja, após o período de restrição os animais apresentam um crescimento mais rápido que aqueles que não passaram pela restrição alimentar (ALLEN, 1990). Este fato, denominado de crescimento compensatório, é comumente empregado no sistema produtivo de bovino de corte com o intuito de manter os animais por mais tempo nas pastagens, diminuindo os custos de alimentação sem prejudicar o ganho de peso total e, conseqüentemente, a lucratividade do confinamento. Também é interessante citar que um tempo de restrição, que corresponde ao período das secas na maior parte do país, não prejudica as características da carcaça e da carne de animais que passaram por estas condições (PEREIRA e AFERRI, 2006).

Os fatores envolvidos no fenômeno de crescimento compensatório, segundo Hornick et al. (1998a), compreendem aumento na ingestão de alimentos, aumento no peso das vísceras ou uma maior eficiência de utilização do alimento. As respostas biológicas de cada animal ao período de carência nutricional variam de acordo com o nível de subnutrição e realimentação e com o estágio de desenvolvimento do animal. Essa resposta é mais bem expressa quanto mais avançada a idade do animal, já que a restrição alimentar em animais jovens pode comprometer o seu desenvolvimento. Em avaliação de animais zebuínos Tolla et al. (2003) observaram diferença entre animais com acesso ad libitum à dieta em relação aos animais com acesso restrito ao alimento quanto ao conteúdo do trato digestivo no momento do abate.

No entanto, faz-se necessário um grande conhecimento de como este processo se desenvolve no animal para que os riscos sejam minimizados, já que, segundo Owens et al. (1993) os animais que sofreram restrição alimentar na fase de recria, a ponto de prejudicar o crescimento, quando forem para o confinamento serão menos eficientes em ganhar peso e depositar gordura na carcaça que aqueles cujo desenvolvimento foi favorecido. Os fatores mais importantes que afetam o crescimento compensatório do bovino são a idade em que ocorre a restrição, a severidade e a duração da mesma. Apesar dos fatores conhecidos envolvidos neste processo, Drouillard et al. (1991) consideraram ainda uma possibilidade de interação entre estes fatores, o que aumenta a complexidade de prever a compensação. Também é importante considerar o valor qualitativo da restrição alimentar (energética ou protéica) e a interdependência destes nutrientes quanto ao metabolismo animal. 
Segundo Klopfenstein et al. (1999), o crescimento compensatório é variável, difícil de estimar, pode ser explicado pelo consumo de $\mathrm{El}_{\mathrm{g}}$ acima da mantença e pode ser reduzido por longos períodos de restrição. O tipo de restrição também afeta a resposta do animal, sendo que maior resposta em crescimento compensatório foi observada em animais que passaram por restrição energética em relação à protéica.

Em acréscimo a toda diversidade de fatores que podem ocorrer durante 0 ganho compensatório, Drouillard et al. (1991) ressaltaram que as diferenças prévias pelas quais os animais passaram, e que não são conhecidas, podem apresentar interações complexas com outras fontes de anomalia, levando a resultados diferentes sobre o estudo deste fenômeno.

O crescimento compensatório tem curta duração, mas verificam-se diversas mudanças no animal durante sua ocorrência. A ingestão de alimentos nas três ou quatro semanas após a restrição alimentar é variável, sendo modificada pelo tamanho do trato gastrintestinal (TGI), pela capacidade de absorção do seu epitélio e pela capacidade do fígado de metabolizar os nutrientes. A exigência de energia metabolizável para mantença é reduzida para animais em compensação em até $20 \%$, segundo o NRC (1996), resultando em maior disponibilidade de energia para produção, em uma mesma ingestão de alimentos. Essa exigência menor está ligada ao menor tamanho dos órgãos internos devido à restrição alimentar.

A energia líquida para crescimento também é reduzida em até $18 \%$ (CARSTENS et al., 1991) indicando uma melhor eficiência de utilização de energia dos animais compensando. Segundo estes mesmos autores, o ganho compensatório pode ser atribuído em grande parte ao aumento no enchimento e no peso do tecido do TGI e outros órgãos internos.

Para estudar os efeitos da limitação na ingestão de energia líquida ou proteína metabolizável no ganho de peso subseqüente a esta fase, Drouillard et al. (1991), mantiveram novilhos em fase de crescimento sob restrição energética e protéica por 77 dias. Esses autores observaram que o crescimento compensatório desses animais foi semelhante, independente da restrição energética ou protéica. Entretanto, na fase de terminação, os animais submetidos à restrição energética tiveram melhores desempenhos que os submetidos à restrição protéica, quando deficiências alimentares foram impostas por períodos mais longos. 


\subsection{Digestibilidade da dieta}

Os processos fermentativos que ocorrem no rúmen são responsáveis pela síntese da proteína microbiana, vitaminas e dos ácidos graxos voláteis. A qualidade e a quantidade destes produtos estão na dependência da natureza do alimento oferecido, da forma como são ofertados bem como de fatores fisiológicos pertinentes ao ambiente ruminal (BARBOSA et al., 2003).

A energia líquida do alimento varia com o nível de alimentação dos animais, e diminui com o aumento na ingestão de alimentos (LOFGREEN and GARRET, 1968), como conseqüência de alterações na digestibilidade dos nutrientes. Hayden et al. (1993) constataram diminuição na digestibilidade da dieta em animais que estavam sendo realimentados, entretanto estes animais foram mais eficientes (alimento ingerido/ganho de peso) no uso dos nutrientes.

A energia digestível adicional necessária para manter bovinos comendo restritamente pode ser compensada pela menor exigência em ED para deposição de tecidos magros que para deposição de gordura (O'DONOVAN, 1984). Neste sentido, a restrição alimentar leve pode favorecer a eficiência de utilização do alimento.

Os ruminantes dependem do ecossistema ruminal e a proteína microbiana é a fonte primária de aminoácido para o metabolismo do ruminante (RUSSELL and COOK, 1995). As bactérias do rúmen respondem diferentemente às fontes $e$ limitações de nitrogênio (TEDESCHI et al., 2000). Quando a taxa de fermentação de carboidrato no rúmen aumenta, as bactérias podem precisar de nitrogênio amino para melhorar suas taxas anabólicas e catabólicas (RUSSELL, 1998).

$\mathrm{Na}$ fase de realimentação Klopfenstein et al. (1999) constataram que os animais se tornaram "comedores agressivos" e a acidose pode ter limitado sua habilidade em expressar o ganho compensatório. Neste sentido, Hersom et al. (2003) ressaltaram a importância do período de adaptação que fornece aos animais condições de ingerirem grandes quantidades de dietas ricas em energia, resultando em maior e mais eficiente ganho de peso. Além disto, quando compararam os dados em peso metabólico dos animais, os autores sugeriram que os novilhos compensando tiveram maior fluxo de sangüíneo no fígado e consumo de oxigênio pelas vísceras, comparados com os animais que não passaram por restrição alimentar. O maior gasto de energia pelos tecidos viscerais em compensação 
indicam um incremento no metabolismo, o qual leva a uma acelerada taxa de crescimento.

\subsection{Perfil hormonal e parâmetros sangüíneos}

Os três principais componentes do animal adulto são ossos, músculos esqueléticos e gordura, que é o tecido mais variável com a taxa de crescimento (WEEKES, 1983). O crescimento do tecido adiposo depende de um aumento coordenado na hipertrofia e hiperplasia do tecido adiposo. O sistema endócrino afeta o balanço entre os processos anabólicos e catabólicos no adipócito e influencia a partição da energia excedente à exigência de mantença entre deposição de músculo e tecido adiposo, e produção de calor. Muitas pesquisas têm sido direcionadas no sentido de entender o sistema de controle endócrino da partição de nutriente a fim de manipular mais eficazmente a produção de carne (WEEKES, 1983).

A regulação do metabolismo energético constitui apenas uma das muitas funções integrativas dos hormônios. Virtualmente, cada processo nos organismos superiores é regulado por um ou mais hormônios: mantença da pressão arterial, volume sangüíneo e equilíbrio eletrolítico, embriogênese, diferenciação sexual, desenvolvimento e reprodução, fome, comportamento alimentar e digestão, para mencionar alguns (LEHNINGER, 2002).

O fator de crescimento semelhante à insulina ou IGF-I é a chave para a síntese de proteína e sua secreção é dependente do hormônio de crescimento $(\mathrm{GH})$ (HORNICK et al., 1998b). A principal ação do hormônio de crescimento no metabolismo de proteína é anabólica (BUTTERY, 1983). Portanto, quanto maior a concentração de $\mathrm{GH}$, maior secreção de IGF-I e maior síntese de proteína. O crescimento é um processo complexo e integrado que envolve a formação e aumento de muitas unidades metabólicas. Obviamente, a deposição máxima de

proteína no animal ocorre quando todo o metabolismo do animal favorece o anabolismo (BUTTERY, 1983).

Durante o período de restrição alimentar diminui a taxa de crescimento o que causa alterações nos níveis de IGF-I, ocorrendo aumento deste hormônio no período de ganho compensatório devido ao acelerado ganho de peso (ELLENBERGER et al., 1989). 
Os hormônios tireóideos estimulam o metabolismo energético, especialmente no fígado e no músculo, ativando a expressão de genes que codificam enzimaschave catabólicas. Os hormônios tireóideos tiroxina (T4) e triiodotironina (T3) são sintetizados na glândula tireóide a partir de uma proteína precursora, a tireoglobulina (LEHNINGER, 2002).

Em trabalho sobre restrição e realimentação Fiems et al. (2007), citando vários autores, comentaram que a restrição alimentar seguida por um período de realimentação pode modificar as concentrações plasmáticas de metabólitos em novilhos, novilhas, touros e vacas. Estes autores afirmaram que as concentrações de ácidos graxos não esterificados e uréia podem aumentar durante períodos de restrição alimentar ou fome.

Durante a fase de ganho compensatório também ocorrem mudanças endócrinas no hormônio de crescimento, no fator de crescimento semelhante à insulina, na insulina e tiroxinas T3 e T4, bem como mudanças na composição corporal e do ganho de peso. Aumento na deposição de proteína foi verificado por alguns pesquisadores no início da compensação devido ao aumento no TGI e no fígado (CARSTENS et al., 1991; BOIN e MOURA, 1977; FONTES et al., 2005b). A composição corporal a um mesmo peso, de animais que exibiram crescimento compensatório pode diferir ou não da composição de animais geneticamente idênticos que não sofreram restrição alimentar, dependendo do nível nutricional após a restrição e do efeito da restrição no tamanho do animal à maturidade.

O tipo de tecido corporal que é depositado durante a fase de compensação, que ocorre com a volta do fornecimento de energia, é dependente principalmente da maturidade fisiológica de cada animal (HAYDEN et al., 1993). Durante a realimentação, os metabólitos no plasma se alteram rapidamente em favor do anabolismo protéico. E também, as concentrações plasmáticas do hormônio de crescimento, insulina, hormônios tiroideanos e IGF-I estão fortemente associados com tecido corporal ganho em novilhos compensando (HAYDEN et al., 1993).

Segundo Lima (2005), em estudo do perfil hormonal de garrotes submetidos à carência energética prolongada, os teores de IGF-I, T3 e T4 se mostraram variáveis precisas para diferenciar os diversos graus de carência energética a que os animais foram submetidos. Para Buttery (1983) existem evidências suficientes sugerindo que as concentrações fisiológicas de hormônios tiroideanos têm importante papel no controle da deposição de proteína muscular. 
Outros parâmetros sangüíneos também são indicativos das alterações metabólicas pelas quais os animais passam no período de restrição alimentar, como a concentração de uréia, glicose e proteína total. A melhor compreensão dos fatores que regem o nitrogênio $(N)$ dietético e a concentração do nitrogênio uréico no sangue (NUS) pode melhorar o uso do NUS para calcular ou predizer não apenas a retenção de $\mathrm{N}$ e o crescimento, mas também a excreção de nitrogênio (HUNTINGTON et al., 2001).

As fontes dietéticas de N, segundo Huntington e Archibeque (1999), incluem ácidos nucléicos, aminoácidos, proteínas, peptídeos, aminas, amidas, nitratos, nitritos, uréia e amônia. $E$, as fontes endógenas incluem células mortas e uréia que retorna ao rúmen pelo epitélio ruminal ou pela saliva. Com exceção de algumas proteínas e $\mathrm{N}$ ligado à fibra em detergente ácido, as fontes de $\mathrm{N}$ são facilmente solúveis e susceptíveis à degradação no rúmen. A evolução da simbiose entre os microrganismos do rúmen e seu hospedeiro, bem como a simbiose entre os próprios microrganismos, tem feito da amônia o principal componente do metabolismo de nitrogênio em ruminantes.

Segundo Huntington et al. (1996), diferentes níveis de concentrado na dieta de novilhos afetam a quantidade de uréia produzida pelo fígado e quanto desta uréia é reciclada dentro do trato digestivo. Os novilhos reciclam $90 \%$ da produção de uréia do fígado quando alimentados com $20 \%$ ou menos de concentrado na dieta. A reciclagem diminui para $64 \%$ com $63 \%$ de concentrado e para $51 \%$ com $90 \%$ de concentrado. Aumento na reciclagem da uréia para o trato intestinal pode favorecer a eficiência no uso de $\mathrm{N}$ para mantença e produção.

Em bovinos, a uréia plasmática é derivada do catabolismo de aminoácidos no fígado e da produção de amônia pelo rúmen quando o nível de nitrogênio degradado excede a quantidade de energia disponível (CABARAUX et al., 2005).

A demanda por proteína para assegurar o crescimento pode afetar a síntese e a concentração sangüínea de uréia em novilhos (HUNTINGTON and ARCHIBEQUE, 1999). A promoção de crescimento de tecido magro reduziu a síntese de uréia em novilhos (EISEMANN et al., 1993). Portanto, a otimização do uso de nitrogênio por gado de corte deve levar em consideração os aspectos relacionados à digestão e absorção de compostos nitrogenados, bem como as demandas dos animais (HUNTINGTON et al., 2001). 
Segundo Lima et al. (2004) a concentração de uréia plasmática pode ser usada para monitorar a ingestão de proteína bruta que deve ser o mais próximo possível das necessidades da vaca, por quatro motivos: o excesso de $\mathrm{N}$ pode prejudicar o desempenho reprodutivo; o excesso de $\mathrm{N}$ aumenta as exigências de energia, uma vez que são necessárias 13,3 kcal de energia digestível para excretar um grama de $\mathrm{N}$; os suplementos protéicos são caros e a grande quantidade de $\mathrm{N}$ excretada gera impacto ambiental negativo (BRODERIK and CLAYTON, 1997). Para Huntington e Archibeque (1999) as três principais áreas de aplicação das informações relacionadas ao uso de $\mathrm{N}$ não protéico por ruminantes são a sincronização da fermentação de carboidratos e nitrogênio no rúmen, o uso do $\mathrm{N}$ como mensurador do status protéico, e o fluxo de $\mathrm{N}$ pelo sistema ecológico.

Por outro lado, Oliveira Júnior et al. (2004) citaram que o nitrogênio uréico plasmático (NUP) não é bom indicador de consumo de proteína, mas pode ser bom indicador da proteína não utilizada (STAPLES et al., 1993 apud OLIVEIRA JÚNIOR et al., 2004). Isso reforça a hipótese de que os animais avaliados pelos autores não estavam sendo capazes de utilizar boa parte da proteína consumida, uma vez que os valores de NUP foram altos, maiores que $16 \mathrm{mg} / \mathrm{dL}$, para dietas que usavam farelo de soja, uréia ou amiréia.

Trabalhando com restrição na ingestão de energia, Fiems et al. (2007) constataram elevações nas concentrações plasmáticas de ácidos graxos não esterificados, nitrogênio ligado a aminoácidos e, também, provocou perda de $\mathrm{N}$ do corpo. As diferenças metabólicas observadas durante a restrição desapareceram no final do período de realimentação.

Em estudo de vacas em terminação Cabaraux et al. (2005) não encontraram relações significativas nas concentrações de glicose plasmática, $\mathrm{N}$-amino e uréia. $\mathrm{O}$ mesmo ocorreu com as concentrações de T3, T4 e IGF-I quando comparadas durante o período de acabamento. Os autores consideraram ainda que estes parâmetros podem variar em função das diferenças de metabolismo relacionadas ao sexo e à idade dos animais.

Pouca quantidade de glicose é absorvida por ruminantes alimentados com forragem e parece que a absorção de glicose apenas ocorre em animais que estejam consumindo grande quantidade de grãos (Bergman, 1973; Lindsay,1978 apud McDOWELL, 1983). Os principais precursores da glicose em ruminantes são o propionato e aminoácidos, sendo que a glicose é necessária para a reciclagem e 
síntese de gordura, como um precursor do glicogênio muscular. Sobre o controle homeostático da glicose em ruminantes é necessário considerar a produção e uso da glicose no corpo, tanto quanto o fornecimento alternativo de substratos energéticos (McDOWELL, 1983).

Estudando o ganho de peso compensatório, Blum et al. (1985) observaram nível mais baixo de glicose durante o período de restrição alimentar quando comparado aos valores observados nos animais controle, possivelmente demonstrando uma gliconeogênese insuficiente.

A determinação de proteínas totais (PT) em plasma de sangue bovino é utilizada como um parâmetro no controle da saúde e nutrição animal (FAO, 1993 apud LUCA e REIS, 2001). Níveis mais baixos são verificados em casos de deficiência de proteína na dieta, insuficiência hepática, aproveitamento inadequado da proteína ingerida, hemorragias e perda da proteína intestinal ou renal (LUCA e REIS, 2001). Segundo Fagliari et al. (1991) os níveis de proteína bruta e das frações protéicas são úteis como medidas auxiliares no diagnóstico de enfermidades. Os autores encontraram níveis estáveis nas concentrações séricas de proteína total e suas frações para animais recém desmamados e novilhas da raça Guzerá.

Em estudos com bezerros recém nascidos Ribeiro et al. (2006) observaram que a quantidade de proteína total pode ser influenciada pelo tempo de latência à primeira mamada, fato que reforça a influência da alimentação nos parâmetros sangüíneos. Canavessi et al. (2000) encontraram valores mais altos para animais Nelore, a partir dos 18 meses de idade quando comparados aos animais dos 8 aos 18 meses de idade. Em estudo de diferentes fontes energéticas Mendes et al. (2005) não observaram influência destes alimentos sobre as concentrações de PT de novilhos.

Assim sendo, a determinação das exigências nutricionais para mantença e ganho de peso de novilhos Nelore em confinamento, com ou sem restrição alimentar e, também, como ocorre o ganho de peso na sua posterior realimentação, são dados importantes para a maximização dos sistemas de produção de novilhos em terminação. A determinação das exigências nutricionais desta raça em condições normais de alimentação ou na subalimentação pode contribuir para o banco de dados brasileiro, pois segundo Valadares Filho et al. (2005), ainda é necessário o desenvolvimento de mais trabalhos de pesquisa nesta área. 


\section{Objetivos}

A hipótese a ser testada neste trabalho é que animais de raças zebuínas possuem exigência de energia para mantença $10 \%$ menor que animais de raças taurinas. Segundo o NRC (1996) a exigência de $E L_{m}$ para taurinos equivale a 77 $\mathrm{kcal} / \mathrm{PV}^{0,75}$. Considerando que a exigência de zebuínos é $10 \%$ menor, encontra-se o valor de 69,3 kcal/PV ${ }^{0,75}$. Para testar esta hipótese foram usados novilhos da raça Nelore em regime de confinamento para terminação.

Portanto, este trabalho teve como objetivos:

1. Verificar as exigências de energia e proteína líquida para mantença e para ganho de peso.

2. Avaliar o efeito da restrição alimentar sobre o desempenho e composição do ganho de peso, bem como o perfil hormonal dos animais, durante a restrição e na realimentação.

3. Avaliar a eficiência biológica e econômica do ganho de peso compensatório em confinamento. 


\section{Material e Métodos}

\section{Local}

Os experimentos foram desenvolvidos no Departamento de Zootecnia da Faculdade de Zootecnia e Engenharia de Alimentos da Universidade de São Paulo FZEA / USP, em Pirassununga, SP. O município de Pirassununga está situado a $21^{\circ}$ $59^{\prime}$ de latitude Sul e $47^{\circ} 26^{\prime}$ de longitude Oeste e a uma altitude de 634 metros. $O$ clima é considerado subtropical tipo cwa Köppen (subtropical, com inverno seco e bem definido e verão quente e chuvoso).

Nesta região há variações na temperatura ambiente em função da passagem de ondas de frio vindas da região sul do país. Durante o período de confinamento houve a passagem de uma forte onda de frio, que provocou queda de $10^{\circ} \mathrm{C}$ na temperatura, o que pode ter influenciado algumas das características avaliadas neste estudo. As variáveis climáticas foram mensuradas próximas às instalações do confinamento pela FZEA.

\section{Confinamento}

O experimento teve dois períodos distintos em seqüência, sendo que no primeiro os animais foram alimentados em três níveis de consumo para estudo de exigência nutricional (Restrição) e no segundo período os animais que passaram pelos menores níveis de alimentação foram alimentados à vontade (Realimentação), como apresentado na Figura 1.

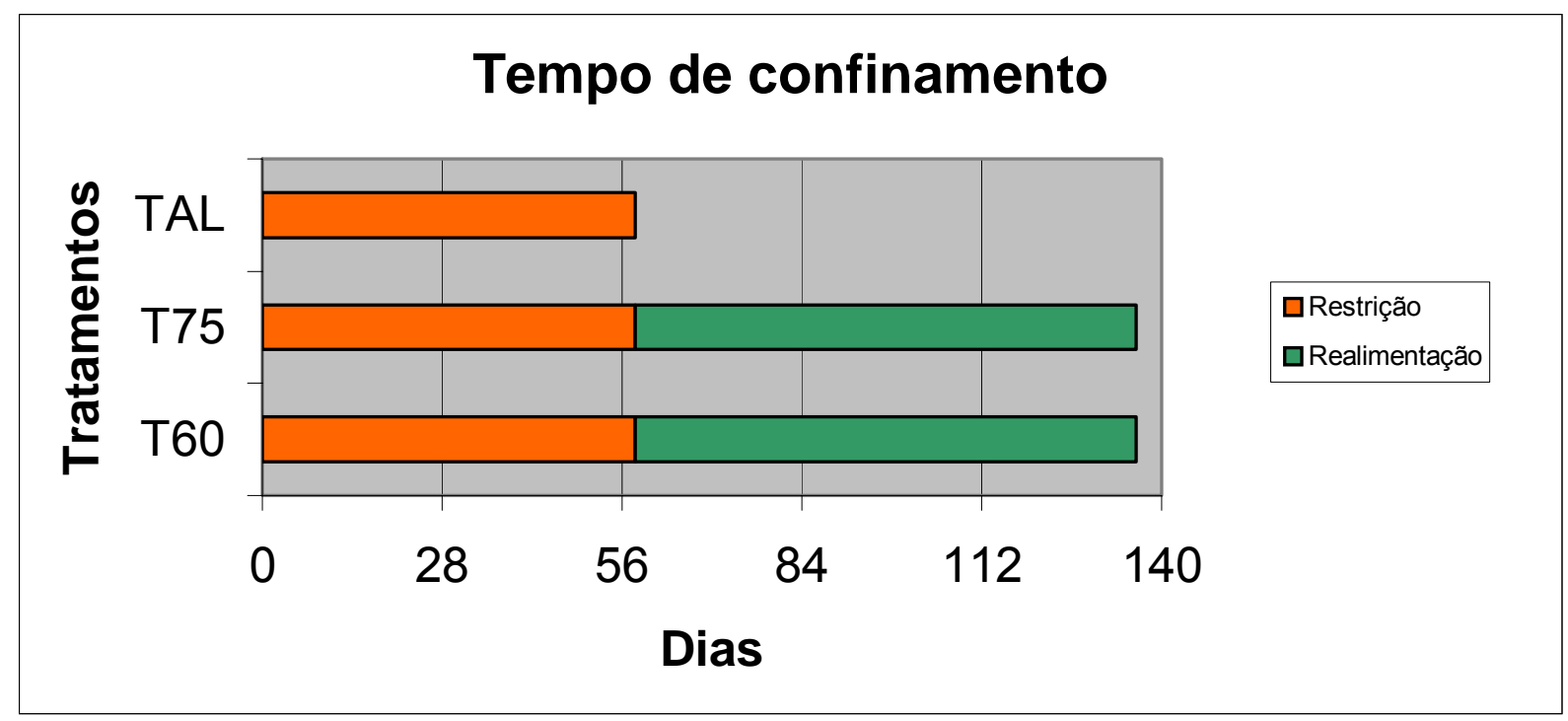

Figura 1 - Tempo de alimentação dos animais na fase de Restrição - Experimento I e na fase de realimentação - Experimento II 


\subsection{Experimento I - Exigências nutricionais (Restrição)}

\subsubsection{Animais}

Foram usados 36 machos castrados da raça Nelore, todos da mesma estação de nascimento, com média de 20 meses de idade e peso inicial de $358,7 \mathrm{~kg}$, quando passaram pelo período de adaptação ao confinamento e à dieta. Os animais foram alojados individualmente em baias com piso parcialmente concretado, que possuem cochos cobertos e bebedouros individuais, compondo três tratamentos com 12 novilhos para cada tratamento. As medidas preventivas para controle de endo e ectoparasitos e a vacinação contra febre aftosa foram realizadas antes dos animais entrarem em adaptação.

\subsubsection{Confinamento}

O confinamento foi desenvolvido nas dependências experimentais do Departamento de Zootecnia da FZEA / USP, sendo o início desta atividade em maio de 2006 e o término em novembro do mesmo ano.

\subsubsection{Alimentação}

Os animais foram alimentados, por 56 dias, com a mesma dieta fornecida em três níveis de ingestão de matéria seca (MS) representando os tratamentos: alimentação ad libitum (TAL), 75 g MS/kg PV ${ }^{0,75}$ (T75) e $60 \mathrm{~g} \mathrm{MS/kg} \mathrm{PV}{ }^{0,75}$ (T60). O alimento concentrado e o volumoso foram pesados, misturados e distribuídos diariamente pela manhã, e as sobras foram recolhidas antes da alimentação, às segundas-feiras, quartas-feiras e sextas-feiras, pesadas e amostradas semanalmente para determinação da MS. O ajuste da dieta oferecida para o grupo controle foi realizado em função da sobra observada, ocorrendo na mesma periodicidade. Para os tratamentos $75 \mathrm{~g} \mathrm{MS} / \mathrm{kg} \mathrm{PV}^{0,75}$ e $60 \mathrm{~g} \mathrm{MS} / \mathrm{kg} \mathrm{PV}^{0,75}$ o fornecimento da dieta foi constante durante os períodos entre as pesagens, uma vez 
que foi determinado em função do peso metabólico inicial do período, para cada animal.

A dieta foi a mesma para todos os tratamentos e períodos variando apenas as quantidades de alimento fornecido diariamente aos animais em função dos tratamentos. A dieta foi formulada com o programa computacional RLM ${ }^{\circledR}$ utilizando alimentos comuns em confinamentos brasileiros como apresentado na Tabela 1.

Tabela 1 - Composição da dieta fornecida aos animais com base na matéria seca

\begin{tabular}{lc}
\hline Ingrediente & $\%$ \\
\hline Milho grão & 20,00 \\
Casca de soja & 57,29 \\
Farelo de soja & 0,71 \\
Uréia & 0,92 \\
Sal mineral & 0,60 \\
Calcário & 0,49 \\
Rumensin ${ }^{\circledR}$ & 0,027 \\
Silagem de sorgo & 20,00 \\
\hline Nutrientes digestíveis totais & 69,38 \\
Proteína bruta & 11,49 \\
Proteína degradável no rúmen & 8,53 \\
\hline
\end{tabular}

Os animais foram pesados a cada intervalo de 28 dias, após jejum hídrico e sólido de 16 horas, compreendendo dois períodos experimentais.

\subsubsection{Análises bromatológicas}

A matéria seca da silagem de sorgo foi realizada quando os animais estavam em período de adaptação, sendo este valor usado no cálculo de alimento a ser oferecido. Também neste período foi realizada amostragem de concentrado e, em ambos, foram realizadas as análises de matéria seca a $65^{\circ} \mathrm{C}(\mathrm{MS})$, nutrientes digestíveis totais (NDT), proteína bruta (PB), extrato etéreo (EE), matéria mineral (MM), fibra em detergente neutro (FDN) e fibra em detergente ácido (FDA), segundo Silva e Queiroz (2002). Os resultados estão na Tabela 2, expressos na matéria seca. 
Tabela 2 - Composição bromatológica (\%) da silagem de sorgo, do concentrado e da dieta

\begin{tabular}{lcccccccccc}
\hline Amostra & MS & NDT $^{1}$ & PB & EE & MM & FDN & FDA & NFDN & NFDA & Lignina \\
\hline Silagem & 37,63 & 65,98 & 4,61 & 1,92 & 4,68 & 54,90 & 34,22 & 2,78 & 2,98 & 4,21 \\
Concentrado & 90,43 & 79,04 & 15,87 & 2,54 & 4,15 & 54,32 & 39,63 & 6,83 & 3,55 & 2,20 \\
Dieta & 79,87 & 76,43 & 13,62 & 2,42 & 4,26 & 54,44 & 38,55 & 6,02 & 3,44 & 2,60
\end{tabular}

${ }^{1}$ Estimado segundo Valadares Filho et al. (2005)

Para estimativa dos nutrientes digestíveis totais (NDT) do volumoso e do concentrado foram usadas as equações citadas por Valadares Filho et al. (2005) descritas a seguir.

- $\quad N D T=P B D+2,25 * A G D+F D N c p D+C N F D-7$, onde:

$P B D$ : proteína bruta digestível.

$A G D$ : ácidos graxos digestíveis.

FDNcpD: fibra em detergente neutro digestível corrigida para cinzas e proteína.

CNFD: carboidrato não fibroso digestível.

Para cálculo da PBD da silagem e do concentrado foram usadas respectivamente as equações:

- $P B D_{V}=P B * e^{\left\{-1,2^{*}(P I D A / P B)\right\}}$

- $P B D_{c}=P B *\left\{1-\left[0,4^{*}(P I D A / P B)\right]\right\}$, onde:

$P B D_{v}$ : proteína bruta digestível para volumoso.

$P B D_{c}$ : proteína bruta digestível para concentrado.

PIDA: proteína ligada à fração FDA.

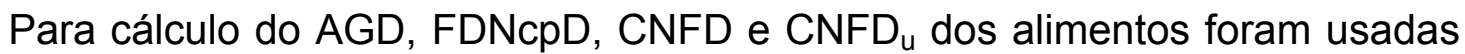
as equações:

- $A G D=(E E-1) \star 100$.

- $F D N c p D=0,75^{\star}(F D N c p-L) *\left\{1-(L / F D N c p)^{0,667}\right\}$, onde:

L: lignina.

- $\quad C N F D=0,98^{\star}(100-(\% P B+\% E E+\% C I N Z A+\% F D N c p))$

- $C N F D_{u}=100-((\% P B-\% P B$ derivado da uréia + peso \% da uréia $)+$ $\%$ FDNcp + \%EE + \% Cinzas), onde:

$C N F D_{u}$ : carboidrato não fibroso digestível para concentrado com uréia.

A partir do NDT das dietas, foram obtidas, através dos fatores apresentados pelo NRC (2000), a energia digestível (ED) e metabolizável (EM). Para isso, 
considerou-se que $1 \mathrm{~kg}$ de NDT equivale a 4,409 Mcal de ED e que EM =0,82*ED (VALADARES FILHO et al., 2005).

\subsubsection{Composição corporal}

A composição corporal foi estimada com o indicador óxido de deutério, a fim de poder repetir a medida nos mesmos animais, estudando assim, a resposta dos mesmos à realimentação. A determinação foi realizada segundo metodologia descrita por Leme (1993), através da injeção de óxido de deutério (Sigma D-44501, com $99,8 \%$ de pureza, pm 20,03) na jugular direita, sendo a quantidade calculada na base de $0,1 \mathrm{~g} / \mathrm{kg}$ de peso vivo, e injetado $5 \mathrm{ml}$ de solução fisiológica antes e após a injeção de óxido de deutério.

Antes da injeção dos produtos citados foi colhida amostra de sangue em tubos heparinizados Vacutainer de $10 \mathrm{ml}$, que foram refrigerados, e posteriormente transferida para tubos plásticos resistentes ao congelamento onde foram armazenadas $\mathrm{a}-20^{\circ} \mathrm{C}$ para posterior análise. Após a aplicação de óxido de deutério os animais permaneceram agrupados sem acesso a água ou alimento. $\mathrm{Na}$ sexta hora após a aplicação do óxido de deutério foi colhida nova amostra de sangue em tubos heparinizados Vacutainer de $10 \mathrm{ml}$ para análise da concentração do marcador e assim poder estimar a quantidade de água no corpo do animal.

A análise de deutério nas amostras de sangue foi feita por meio de espectrometria de massa, segundo metodologia descrita por Coleman et al. (1982), onde a água é separada do sangue por destilação a vácuo e recolhida em armadilha a $-70{ }^{\circ} \mathrm{C}$ e decomposta pela reação com zinco metálico a $600{ }^{\circ} \mathrm{C}$ sob sistema de vácuo.

O espaço de deutério (EDT) foi calculado pela fórmula:

$E D T=\frac{\mathrm{mg} \mathrm{D}_{2} \mathrm{O} \text { injetado }}{\mathrm{mg} / \mathrm{ml}_{2} \mathrm{O} \text { Final }-\mathrm{mg} / \mathrm{ml}_{2} \mathrm{O} \text { Inicial }}$.

Para as estimativas da composição química in vivo do corpo vazio de ruminantes através de métodos de diluição isotópica é necessária uma estimativa do peso do corpo vazio (PCVZ) a partir do peso vivo em jejum $\left(\mathrm{PV}_{\mathrm{j}}\right)$. Para isto, foi obtida uma equação a partir dos dados destes animais ao final do período experimental, quando foram abatidos e determinado o peso do corpo vazio.

$\checkmark$ Equação para estimativa do peso do corpo vazio: 
$\operatorname{PCVZ}(\mathrm{kg})=-15,74911+0,98517 \times P V j(\mathrm{~kg}),\left(\mathrm{R}^{2}=0,96\right.$ e $\left.\mathrm{S}_{\mathrm{y} \cdot \mathrm{x}}=8,64\right)$.

A seguir são apresentadas as equações para estimar a composição química do corpo vazio de bovinos machos castrados da raça Nelore, segundo Leme (1993).

$\checkmark$ Estimativa da porcentagem de água no corpo vazio: Água $(\%)=65,9654+(0,0977 \times E D T)-(0,0909 \times P V j),\left(R^{2}=0,83\right.$ e $\left.\mathrm{S}_{\mathrm{y} \cdot \mathrm{x}}=1,33\right)$.

$\checkmark$ Estimativa da quantidade de matéria seca no corpo vazio: $M S=P C V Z-$ Água.

$\checkmark$ Estimativa da porcentagem de gordura:

Gordura $(\%)=93,92968-1,27598 \times$ Água $(\%),\left(R^{2}=0,97\right.$ e $\left.S_{y \cdot x}=0,62\right)$.

$\checkmark$ Estimativa da quantidade de proteína na matéria seca do corpo vazio sem gordura através da relação entre proteína e água igual a 0,3009.

$\checkmark$ Estimativa da quantidade de cinzas na matéria seca do corpo vazio sem gordura através da relação entre cinzas e água igual a 0,0747.

Quando houve problema na aplicação de $\mathrm{D}_{2} \mathrm{O}$ os dados referentes àquele animal foram descartados para o estudo de exigências, mas foram usados para as outras características avaliadas.

\subsubsection{Digestibilidade da dieta}

A digestibilidade foi estimada por indicador, usando foi a fibra em detergente ácido indigestível $\left(F D A_{i}\right)$ que, segundo Zeoula et al. (2002), foi considerado um bom indicador na estimativa dos coeficientes de digestibilidade da MS e da MO.

Foram usados seis animais de cada tratamento dos quais foram colhidas fezes diretamente no reto. As colheitas foram realizadas no meio do período experimental, sendo feitas na tarde de um dia e na manhã do dia seguinte, sempre que os animais estivessem com alimentação e água à vontade.

As amostras de fezes foram armazenadas congeladas a $-18{ }^{\circ} \mathrm{C}$, para posterior processamento e análise. Depois de descongeladas, foram secas em estufa com circulação forçada de ar, a $65^{\circ} \mathrm{C}$ por 72 horas, e, em seguida, trituradas em moinho tipo Willey, com peneira com furos de $2 \mathrm{~mm}$ de diâmetro, e acondicionadas em sacos plásticos e congeladas para posterior análise. As 
amostras dos alimentos oferecidos e das sobras do cocho de cada animal também foram secas a $65^{\circ} \mathrm{C}$, moídas e congeladas a $-18^{\circ} \mathrm{C}$.

Para a determinação da FDA $_{i}$ foram pesadas em duplicata seis gramas das amostras de alimentos, sobras e fezes que foram colocadas individualmente em saquinhos de náilon de $10 \times 17 \mathrm{~cm}$, com diâmetro de poros de $53 \mu$ (Ankon). Usando quatro animais da raça Nelore com fístulas ruminais, todas as amostras foram incubadas no rúmen simultaneamente, por 144 horas. Após este período foram lavadas em água corrente e secas em estufa com circulação forçada de ar, a $65^{\circ} \mathrm{C}$ por 72 horas. Estas amostras foram secas a $105^{\circ} \mathrm{C}$ e retiradas sub-amostras para determinação da FDAi.

Os valores encontrados foram usados para calcular a digestibilidade das dietas segundo a fórmula descrita por Zeoula et al. (2002):

$$
D M S(\%)=100-\left[\left(\frac{\% \text { FDAiAli }}{\% \text { FDAiFez }}\right) \times 100\right] \text {, onde: }
$$

DMS: digestibilidade da matéria seca, FDAiAli: FDAi no alimento ingerido, FDAiFez: FDAi nas fezes.

\subsubsection{Determinação das exigências de energia e proteína}

Segundo Valadares Filho et al. (2005) a exigência de energia líquida para mantença tem sido calculada como sendo o antilogaritmo do intercepto da equação de regressão entre o logaritmo da produção de calor e a ingestão de energia metabolizável.

A produção de calor (PC) foi calculada segundo Lofgreen e Garrett (1968), como:

$P C=I E M-E R$, onde:

IEM: ingestão de energia metabolizável.

ER: energia retida.

Neste trabalho, a energia retida foi calculada pelo método da determinação da composição corporal por diluição isotópica.

A exigência de energia líquida para ganho de peso $\left(E L_{g}\right)$ foi determinada como a energia depositada no ganho, como preconizado por Lofgreen e Garrett 
(1968). A equação para predição da ER foi calculada segundo o NRC 1984 (NRC, 1984), onde:

$E R=b^{*} P C V z^{0,75} G P C V z{ }^{a}$, onde:

$a=$ coeficiente da equação de regressão entre o logaritmo da energia retida por quilo de peso de corpo vazio e o logaritmo do ganho diário de peso de corpo vazio, $b=$ antilogaritmo do intercepto da mesma equação de regressão.

A eficiência de uso da energia metabolizável para ganho de peso ou $\mathrm{k}_{\mathrm{g}}$ foi calculada segundo Valadares Filho et al. (2006). Foi considerado o coeficiente de inclinação da reta da equação de regressão entre a energia retida diariamente por quilo de peso metabólico e a ingestão diária de energia metabolizável por quilo de peso metabólico como a eficiência de utilização da energia para ganho de peso $\left(\mathrm{k}_{\mathrm{g}}\right)$.

A exigência de proteína líquida para ganho de peso $\left(P L_{g}\right)$ foi determinada como a proteína retida (VALADARES FILHO et al., 2005).

A determinação de exigência de proteína metabolizável para mantença seguiu o modo de cálculo do NRC (1996) que sugere a metodologia de Wilkerson et al. (1993), onde o intercepto da equação de regressão do consumo de proteína metabolizável (g/dia) em função do ganho de peso ( $\mathrm{kg} / \mathrm{dia})$ dos animais foi dividido pelo peso vivo médio metabólico dos animais. Para cálculo da ingestão de proteína metabolizável foi considerado que:

$\checkmark$ A dieta possuía 4,99\% de proteína não degradável no rúmen (RLM) e que esta possui digestibilidade de 80\% (NRC, 1996).

$\checkmark$ A síntese de proteína microbiana equivale a $120 \mathrm{~g}$ PMic / kg de NDT, proposto por Valadares Filho et al. (2006).

$\checkmark$ O NDT da dieta foi de $76,43 \%$.

$\checkmark$ A fibra efetiva da dieta calculada pelo $\mathrm{CNCPS}^{\circledR}$ foi de $24 \%$ da matéria seca.

$\checkmark$ A proteína bruta microbiana é igual à síntese de proteína microbiana multiplicada pelo teor de NDT multiplicado pelo fator de correção para fibra em detergente neutro efetiva, que para dietas acima de $20 \%$ de fibra efetiva é 1 (NRC, 1996).

$\checkmark$ A proteína verdadeira microbiana equivale a $80 \%$ e sua digestibilidade é de $80 \%$, equivalente a $64 \%$.

$\checkmark$ A proteína metabolizável total é a soma da proteína verdadeira mais a proteína de origem microbiana. 
$\checkmark$ A quantidade de proteína metabolizável por quilo de matéria seca da dieta foi multiplicada pelo consumo diário individual dos animais.

\subsubsection{Perfil hormonal e parâmetros sangüíneos}

No $8^{\circ}, 27^{\circ}$ e $55^{\circ}$ dia de confinamento foram colhidas amostras de sangue de seis animais por tratamento, por meio de venipunctura da jugular externa em tubos heparinizados Vacutainer de $10 \mathrm{ml}$ (BRODERICK and CLAYTON, 1997). As amostras foram colhidas antes da alimentação dos animais, mas os mesmos não passaram por jejum hídrico ou sólido. As amostras foram resfriadas e centrifugadas a 3.500 x g por 15 minutos a $10^{\circ} \mathrm{C}$, para obtenção do plasma, que foi armazenado em tubos Eppendorf, em duplicata, a $-20^{\circ} \mathrm{C}$ para as posteriores dosagens.

\subsubsection{Concentração plasmática de IGF-I, T3 e T4}

A obtenção das concentrações de IGF-I no plasma foi realizada por imunoensaio pós-extração utilizando o kit DSL-10-5600 ACTIVE ${ }^{\circledR}$ IGF-1 ELISA (Diagnostic Systems Laboratories, Inc), segundo as indicações do fabricante.

Para a determinação de $\mathrm{T}_{3}$ e $\mathrm{T}_{4}$ foram realizados procedimentos de enzima imunoensaio pelos kits DSL10-3100S ACTIVE ${ }^{\circledR}$ T3 (EIA) (Diagnostic Systems Laboratories, Inc) e DSL-10-3200 ACTIVE ${ }^{\circledR}$ T4 (EIA) (Diagnostic Systems Laboratories, Inc), respectivamente, segundo as indicações do fabricante.

\subsubsection{Concentração de glicose, proteína total e nitrogênio}

As concentrações de glicose, proteína total e nitrogênio no plasma foram determinadas pelos kits comerciais da empresa Laborlab ${ }^{\circledR}$, sendo GLICOSE MÉTODO ENZIMÁTICO, PROTAL MÉTODO COLORIMÉTRICO e URÉIA MÉTODO ENZIMÁTICO, respectivamente, segundo especificações do fabricante. 


\subsection{Experimento II - Realimentação e ganho compensatório}

Para que fosse possível fazer uma comparação entre o que ocorre quando os animais passam ou não por restrição alimentar, os tratamentos T60 e T75, em realimentação, foram comparados ao tratamento TAL. A comparação foi realizada por período de 78 dias, em que todos os animais foram alimentados à vontade $\mathrm{e}$ aconteceu em fases distintas do confinamento como pode ser observado na Figura 2.

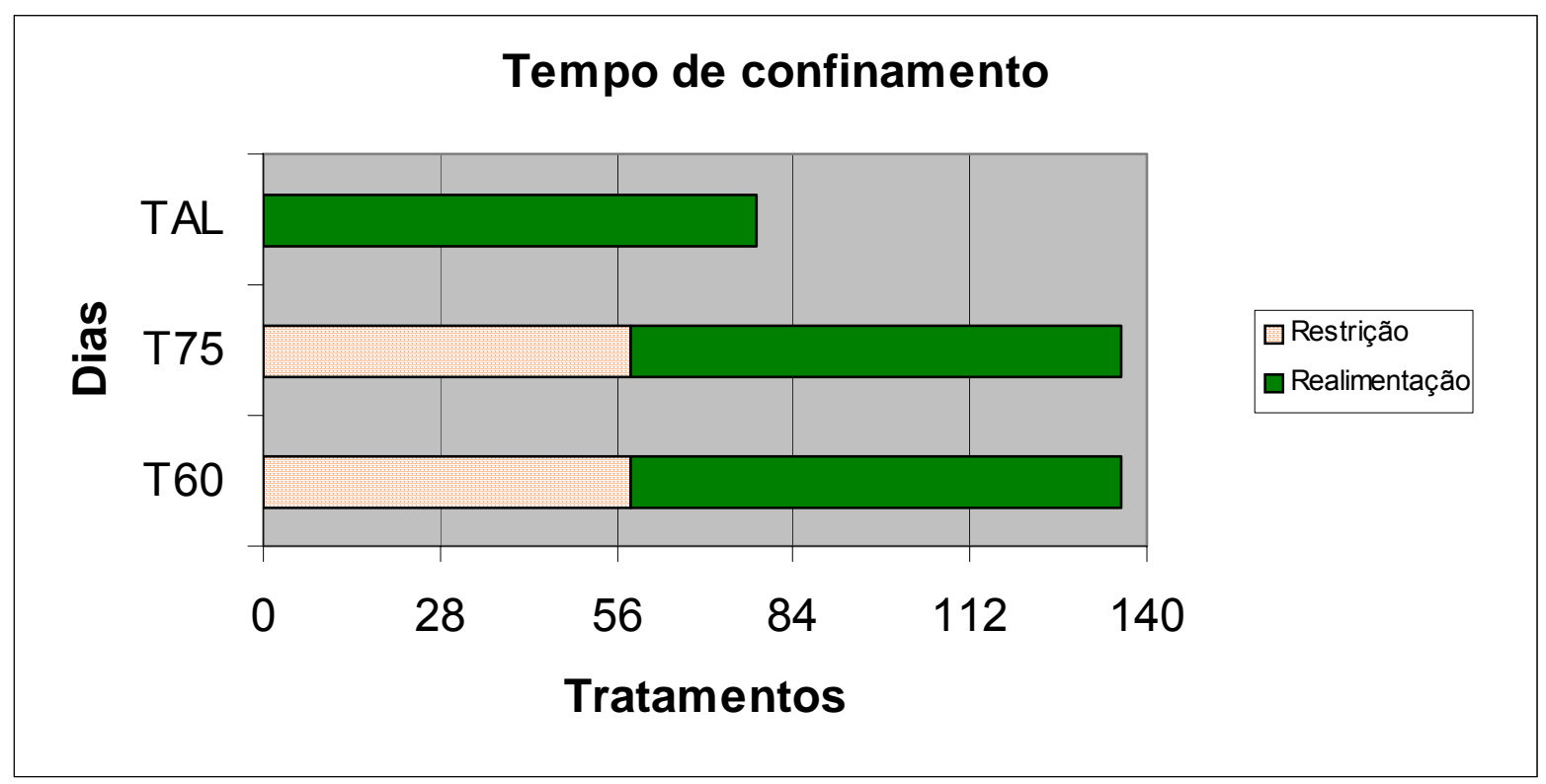

Figura 2 - Tempo de confinamento e especificação dos tratamentos usados na realimentação

\subsubsection{Animais}

Os animais dos tratamentos T60 e T75 do Experimento I foram usados para a execução do Experimento II, quando estavam com média de 22 meses de idade e peso vivo de $387,1 \mathrm{~kg}$. Os animais continuaram alojados em baias individuais, compondo 2 tratamentos, sendo 12 indivíduos para cada tratamento.

\subsubsection{Confinamento}

O confinamento foi desenvolvido nas dependências experimentais do Departamento de Zootecnia da FZEA/USP, e o início desta atividade foi na 
seqüência do $58^{\circ}$ dia do Experimento I, quando todos os animais dos tratamentos T60 e T75 receberam alimentação ad libitum até o $136^{\circ}$ dia.

\subsubsection{Alimentação}

A dieta empregada seguiu a mesma proporção do período anterior, usando o mesmo concentrado e silagem de milho, oferecida uma vez ao dia pela manhã. As pesagens dos animais foram realizadas a cada intervalo de 28 dias, após jejum completo de 16 horas.

As sobras de alimento foram recolhidas diariamente, pesadas e amostradas para determinação da MS, por um período de 10 dias, nos quais o consumo de ração era ajustado diariamente. Foi usada a ingestão de alimentos do tratamento TAL, em porcentagem do peso vivo no $58^{\circ}$ dia de confinamento, como parâmetro para estimar a quantidade de dieta oferecida no início desta segunda fase. Após este período, o consumo de alimentos era ajustado três vezes por semana, quando também era pesada a sobra de alimento oferecido e realizada amostragem da sobra para determinação da matéria seca.

\subsubsection{Análises bromatológicas}

A matéria seca da silagem de milho foi determinada quando os animais estavam no primeiro experimento, sendo este valor usado no cálculo de alimento a ser oferecido. Para este experimento foi realizada amostragem de volumoso e concentrado e em ambos foram realizadas as análises bromatológicas. Os resultados são apresentados na Tabela 3, expressos na matéria seca.

Tabela 3 - Composição bromatológica da silagem de milho, do concentrado e da dieta expressos em \% da matéria seca

\begin{tabular}{lcccccccccc}
\hline Amostra & MS & NDT $^{1}$ & PB & EE & MM & FDN & FDA & NFDN & NFDA & Lignina \\
\hline Silagem & 30,47 & 64,05 & 8,12 & 5,35 & 4,40 & 48,64 & 33,94 & 2,56 & 2,64 & 4,75 \\
Concentrado & 89,73 & 76,87 & 17,00 & 2,44 & 5,03 & 44,72 & 38,35 & 6,89 & 2,67 & 3,23 \\
Dieta & 77,88 & 74,31 & 15,22 & 3,02 & 4,90 & 45,50 & 37,47 & 6,02 & 2,66 & 3,53
\end{tabular}

\footnotetext{
${ }^{1}$ Estimado segundo Valadares Filho et al. (2005)
} 


\subsubsection{Composição corporal}

A composição corporal foi estimada segundo os mesmos procedimentos citados no item 4.1.3. do Experimento I.

Para estimar a composição corporal inicial foi usada a determinação por óxido de deutério do $58^{\circ}$ dia do Experimento I e os mesmos procedimentos realizados foram repetidos no final desta segunda fase, ou seja, no $77^{\circ}$ dia deste Experimento, obtendo os dados de composição corporal de cada indivíduo no período de realimentação.

\subsubsection{Digestibilidade da dieta}

O ensaio de digestibilidade foi conduzido com seis animais de cada tratamento, quando estavam no $27^{\circ}$ dia de realimentação, e seguiram os mesmos procedimentos descritos para o Experimento I.

\subsubsection{Perfil hormonal e parâmetros sanguíneos}

Nos dias 14, 28, 56 e 75 do período de realimentação, 24 horas antes das pesagens, foram colhidas amostras de sangue de seis animais por tratamento, por meio de venipunctura da jugular externa direita em tubos Vacutainer de $10 \mathrm{ml}$. Foram usados os mesmos animais do Experimento I. As amostras foram colhidas e processadas da mesma forma que no Experimento I, sendo realizadas as mesmas análises.

\subsubsection{Abate}

Após 78 dias de confinamento de terminação os animais foram abatidos no Abatedouro Escola da Prefeitura do Campus Administrativo de Pirassununga (PCAPS-USP). Os animais foram atordoados com pistola pneumática para esta finalidade, seguido de sangria, evisceração, limpeza e pesagem das meias carcaças quentes. Durantes estes procedimentos foram pesados o fígado e a gordura pélvica renal e inguinal. As carcaças foram colocadas na câmara frigorífica com temperatura 
entre 0 e $1^{\circ} \mathrm{C}$, por 24 horas. Os pesos de carcaça foram usados para cálculo do rendimento de carcaça.

Foram retiradas amostras da $9^{\mathrm{a}}-10^{\mathrm{a}}-11^{\mathrm{a}}$ costelas para estimar a composição do corpo vazio pela seção $\mathrm{HH}$. A quantidade de água no corpo vazio foi estimada pela equação de Lanna (1988) citada por Putrino (2006):

$\checkmark \%$ água no $C V z=24,1936+(0,6574$ * \% água na seção $H H), R^{2}=0,911 \mathrm{e}$ $S_{y \cdot x}=0,82$.

A quantidade de extrato etéreo, proteína e cinzas no corpo vazio foram determinadas pelas equações desenvolvidas por Leme et al. (1994):

$\checkmark \%$ extrato etéreo no $\mathrm{CVz}=93,92968-(1,27598$ * \% água no $\mathrm{CVz}), \mathrm{R}^{2}=0,97$ e $S_{y \cdot x}=0,62$.

$\checkmark$ Estimativa da quantidade de proteína no corpo vazio foi determinada através da relação entre proteína e água igual a 0,3009.

$\checkmark$ Estimativa da quantidade de cinzas no corpo vazio foi determinada através da relação entre cinzas e água igual a 0,0747.

\subsection{Avaliação econômica}

Para avaliar a eficiência bioeconômica do ganho de peso em confinamento foram usados os dados de ingestão total de matéria seca (MSI), média por tratamento e por experimento.

Os valores dos alimentos, usados para calcular o custo do quilo de matéria seca fornecida aos animais, foram encontrados no Informativo Pecuário Semanal Boi \& Companhia (SCOT CONSULTORIA, 2006). O custo da dieta (expressa em matéria seca) foi de $\mathrm{R} \$ 0,2549$.

O objetivo foi quantificar, em reais, o gasto com a ingestão diária de matéria seca (R\$MSI/dia), por quilo de ganho de peso vivo ( $\mathrm{R} / \mathrm{kg}$ GPV) e por quilo de carcaça depositada (R\$/kg GC), que foram obtidos pelas fórmulas:

$R \$ M S I /$ dia $=(M S I$ diariamente * $R \$ 0,2549)$

$R \$ / k g$ GPV $=(M S I * R \$ 0,2549) /($ Peso vivo inicial - Peso vivo final)

$R \$ / \mathrm{kg} G C=(M S I * R \$ 0,2549) /($ Peso carcaça inicial - Peso carcaça final $)$ 
Para determinar o peso de carcaça inicial foi considerado um rendimento de carcaça de 52\%, aplicado ao peso vivo inicial. Para o Experimento I foi considerado o mesmo rendimento para o peso final.

Para o Experimento II, o peso de carcaça final usado foi o peso de carcaça quente, observado uma hora após o abate.

\subsection{Análise estatística}

O delineamento experimental usado para os Experimentos I e II foi o inteiramente casualizado com três tratamentos e 12 repetições, segundo o modelo: $Y_{i}=\mu+t_{i}+e_{i j}$, onde:

$Y_{i}=$ observação referente ao i-ésimo tratamento

$\mu=$ média geral

$\mathrm{t}_{\mathrm{i}}=$ efeito do i-ésimo tratamento

$e_{i j}=$ erro inerente a cada observação NID $(0, \delta 2 e)$

Para o estudo de digestibilidade foram usados quatro animais por tratamento e para os parâmetros sangüíneos foram avaliados seis animais por tratamento. Os dados foram avaliados pela análise de variância e as médias dos tratamentos foram comparadas pelo teste de média T-Student. As análises foram feitas utilizando-se o procedimento MIXED do programa SAS ${ }^{\circledR}$ (1989).

Foram analisadas como medida repetida no tempo as variáveis: peso, ingestão de matéria seca total e diária, eficiência alimentar, ingestão de matéria seca por quilo de peso metabólico, $\mathrm{R} \$$ por quilo de ganho de peso vivo, $\mathrm{R} \$$ por quilo de ganho de carcaça, glicose, proteína total, nitrogênio uréico no plasma, IGF-I, T3 e T4. Os dados de T3 e T4 foram analisados na forma logarítmica, mas os resultados foram expressos nos valores originais. Sempre que houve interação entre os efeitos de tempo e tratamento os dados foram analisados segundo os desdobramentos necessários.

Foram analisadas como medidas independentes as variáveis: digestibilidade, peso vivo final, peso de carcaça quente, rendimento de carcaça quente, peso do fígado e gordura renal, pélvica e inguinal.

As equações necessárias para os cálculos de exigência nutricional foram obtidas por meio do programa SAS ${ }^{\circledR}$. 


\subsection{Experimento I - Exigências nutricionais (Restrição)}

\subsubsection{Desempenho}

O ganho de peso médio diário observado foi de $0,297 \mathrm{~kg}$ para o tratamento T60, 0,669 kg para o tratamento T75 e 1,204 kg para o tratamento TAL. Estes valores ficaram próximos do esperado, que era de 0,200, 0,700 e 1,200 kg de ganho de peso em jejum para cada um dos três tratamentos, caracterizando diferentes taxas e composição do ganho de peso.

$O$ peso vivo em jejum dos animais apresentou interação $(P<0,001)$ entre os fatores tratamento e tempo. Foi observado efeito quadrático $(P<0,001)$ para T60, onde $Y_{T 60}=363,37-0,3506 X+0,009166 X^{2}$, e linear $(P<0,001)$ para T75 e TAL, onde $Y_{T 75}=361,12+0,6691 X$ e $Y_{T A L}=354,77+1,2038 X$. Isto indica que 0 tratamento com o menor ganho de peso passou por um período inicial de adaptação à menor taxa de ganho, provavelmente porque estava numa velocidade de ganho maior no período que precedeu o experimento. Para os outros dois tratamentos o ganho linear observado diferiu quanto à inclinação da reta, conforme demonstram os coeficientes das equações descritas anteriormente, evidenciando as diferenças na velocidade do ganho, como pode ser observado na Figura 3 que apresenta a evolução do peso vivo em jejum dos animais. 


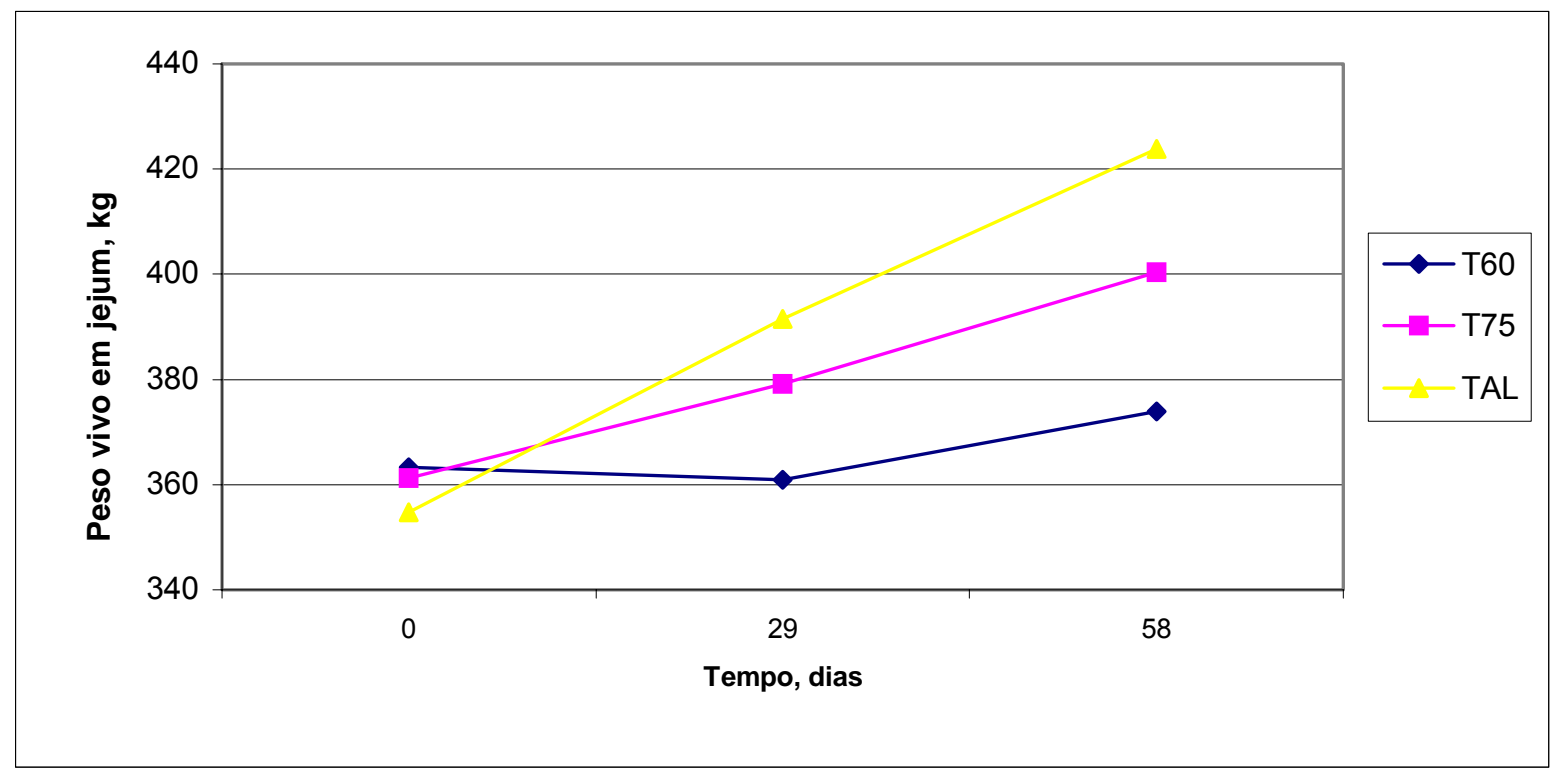

Figura 3 - Média do peso vivo em jejum dos animais por tratamento no $1^{\circ}(0), 29^{\circ} \mathrm{e}$ $58^{\circ}$ dia de confinamento

A evolução do peso vivo no tempo apresentou efeito linear $(P=0,035)$ para o $58^{\circ}$ dia de confinamento, $Y=311,27+1,1415 X$, evidenciando que ao final do experimento os animais apresentavam diferentes pesos e, portanto, diferentes taxas de ganho de peso, dentro do que era esperado para esta variável.

A ingestão de matéria seca por quilo de peso metabólico, para os tratamentos T60 e T75, foi descrita no Material e Métodos, cabendo ainda considerar a ingestão do tratamento TAL. Como os animais estavam recebendo alimento à vontade, a ingestão foi sendo alterada ao longo do período experimental, e o valor médio de ingestão observado foi de $103 \mathrm{~g} / \mathrm{kg} \mathrm{PV}^{0,75}$. Os valores observados para ingestão de matéria seca, em porcentagem do peso vivo foram de 1,19, 1,52 e 2,23\% para os tratamentos T60, T75 e TAL, respectivamente.

\subsubsection{Composição corporal}

A composição corporal foi estimada pelo método de diluição isotópica. Os valores médios, máximos e mínimos da concentração do $\mathrm{D}_{2} \mathrm{O}$ para os tempos zero (EDT0), seis a oito horas após a aplicação (EDT6-8) e a quantidade de água (QA), estão na Tabela 4. 
Tabela 4 - Valores médios, mínimos e máximos de D2O injetado (QI) e no sangue nos tempos zero (EDT0) e 6-8 horas após (EDT6-8) e quantidade de água (QA), nas três datas de avaliação

\begin{tabular}{lcccc}
\hline Inicial & QI $(\mathrm{g})$ & EDT0 $(\mathrm{mg} / \mathrm{L})$ & EDT6-8 $(\mathrm{mg} / \mathrm{L})$ & QA $(\mathrm{L})$ \\
\hline Média & 37,01 & 150,01 & 282,29 & 279,83 \\
Mínimo & 30,63 & 148,59 & 272,13 & 233,70 \\
Máximo & 42,93 & 150,99 & 295,54 & 334,84 \\
\hline Final Exp. I & QI $(\mathrm{g})$ & EDT0 $(\mathrm{mg} / \mathrm{L})$ & EDT6-8 $(\mathrm{mg} / \mathrm{L})$ & QA $(\mathrm{L})$ \\
\hline Média & 43,54 & 150,65 & 297,09 & 297,41 \\
Mínimo & 37,23 & 148,57 & 286,51 & 260,48 \\
Máximo & 51,02 & 152,93 & 309,51 & 350,84 \\
\hline Final Exp. II & QI $(\mathrm{g})$ & EDT0 $(\mathrm{mg} / \mathrm{L})$ & EDT6-8 $(\mathrm{mg} / \mathrm{L})$ & QA $(\mathrm{L})$ \\
\hline Média & 51,26 & 151,33 & 308,02 & 327,21 \\
Mínimo & 43,69 & 150,67 & 296,91 & 300,07 \\
Máximo & 60,23 & 151,89 & 318,23 & 378,81 \\
\hline
\end{tabular}

Os pesos dos animais no início e final do período experimental, bem como a composição corporal inicial, estão apresentados na Tabela 5.

Tabela 5 - Peso em jejum, peso do corpo vazio e composição percentual do corpo vazio

\begin{tabular}{lccc}
\hline \multirow{2}{*}{ Característica } & \multicolumn{3}{c}{ Tratamentos } \\
\cline { 2 - 4 } & $\mathrm{T} 60$ & $\mathrm{~T} 75$ & $\mathrm{TAL}$ \\
\hline Período de confinamento (dias) & 58 & 58 & 58 \\
Peso vivo jejum inicial $(\mathrm{kg})$ & 364,9 & 361,17 & 356,15 \\
Peso vivo jejum final $(\mathrm{kg})$ & 382,1 & 400,42 & 425,75 \\
Peso corpo vazio inicial $(\mathrm{kg})$ & 343,7 & 340,07 & 335,13 \\
Peso corpo vazio final $(\mathrm{kg})$ & 360,7 & 378,74 & 403,70 \\
\hline & Composição do corpo vazio inicial \\
\hline \% Água & 59,91 & 60,54 & 61,09 \\
\% Extrato etéreo & 17,48 & 16,69 & 15,98 \\
\% Proteína & 18,03 & 18,22 & 18,38 \\
\% Cinzas & 4,48 & 4,52 & 4,56 \\
Energia (Mcal/kg) & 2,66 & 2,60 & 2,54 \\
\hline & Composição do corpo vazio final \\
\hline \% Água & 59,26 & 58,89 & 57,97 \\
\% Extrato etéreo & 18,31 & 18,79 & 19,96 \\
\% Proteína & 17,83 & 17,72 & 17,44 \\
\% Cinzas & 4,43 & 4,40 & 4,33 \\
Energia (Mcal/kg) & 2,73 & 2,77 & 2,86 \\
\hline
\end{tabular}

Os valores de composição do corpo vazio observados foram semelhantes aos dados de Putrino (2002) que estimou a composição por meio de abate de alguns dos animais experimentais. A composição do corpo vazio encontrada por Putrino (2002) com novilhos Nelore foi de 59,60 a $60,69 \%$ de água, 17,05 a $18,01 \%$ de extrato 
etéreo, de 17,29 a 17,64\% de proteína, de 4,23 a 4,32\% de cinzas e de 2,55 a 2,66 $\mathrm{Mcal} / \mathrm{kg}$ de energia.

$\mathrm{Na}$ Tabela 6 encontram-se as quantidades de água, gordura, proteína e cinzas no corpo vazio dos animais no início e final do período experimental.

Tabela 6 - Composição química do corpo vazio inicial e final

\begin{tabular}{|c|c|c|c|}
\hline \multirow{3}{*}{ Característica } & \multicolumn{3}{|c|}{ Tratamentos } \\
\hline & T60 & T75 & TAL \\
\hline & \multicolumn{3}{|c|}{ Composição inicial } \\
\hline Água, kg & 204,86 & 205,39 & 204,09 \\
\hline Extrato etéreo, $\mathrm{kg}$ & 60,07 & 57,36 & 54,01 \\
\hline Proteína, kg & 61,64 & 61,80 & 61,41 \\
\hline Cinzas, kg & 15,30 & 15,34 & 15,25 \\
\hline \multirow[t]{2}{*}{ Energia, Mcal/kg } & 2,66 & 2,60 & 2,54 \\
\hline & \multicolumn{3}{|c|}{ Composição final } \\
\hline Água, kg & 211,21 & 222,73 & 233,25 \\
\hline Extrato etéreo, $\mathrm{kg}$ & 65,55 & 71,55 & 81,57 \\
\hline Proteína, kg & 63,55 & 67,02 & 70,19 \\
\hline Cinzas, kg & 15,78 & 16,64 & 17,42 \\
\hline Energia, Mcal/kg & 2,73 & 2,77 & 2,86 \\
\hline
\end{tabular}

As taxas de deposição dos componentes corporais e a composição do ganho de peso vazio dos animais são apresentadas na Tabela 7.

Tabela 7 - Taxa de deposição dos componentes químicos corporais e composição do ganho de peso vazio

\begin{tabular}{|c|c|c|c|}
\hline \multirow{3}{*}{ Característica } & \multicolumn{3}{|c|}{ Tratamentos } \\
\hline & T60 & T75 & TAL \\
\hline & \multicolumn{3}{|c|}{ Taxa de deposição } \\
\hline Ganho de peso jejum, kg/dia & 0,297 & 0,677 & 1,207 \\
\hline $\begin{array}{l}\text { Ganho de peso vazio, kg/dia } \\
\text { (estimado do PVj) }\end{array}$ & 0,293 & 0,667 & 1,189 \\
\hline Água, kg/dia & 0,133 & 0,299 & 0,503 \\
\hline Extrato etéreo, $\mathrm{kg} / \mathrm{dia}$ & 0,105 & 0,245 & 0,475 \\
\hline Proteína, kg/dia & 0,040 & 0,090 & 0,151 \\
\hline Cinzas, kg/dia & 0,010 & 0,022 & 0,038 \\
\hline Soma & 0,288 & 0,656 & 1,167 \\
\hline \multirow[t]{2}{*}{ Energia, Mcal/dia } & 1,21 & 2,80 & 5,31 \\
\hline & \multicolumn{3}{|c|}{ Composição do ganho de peso vazio } \\
\hline \% Água & 43,43 & 44,66 & 42,57 \\
\hline$\%$ Extrato etéreo & 40,26 & 38,56 & 41,44 \\
\hline \% Proteína & 13,07 & 13,44 & 12,81 \\
\hline$\%$ Cinzas & 3,24 & 3,34 & 3,18 \\
\hline Energia (Mcal/kg) & 4,42 & 4,29 & 4,52 \\
\hline
\end{tabular}


Os valores de composição do ganho de peso vazio para extrato etéreo foram semelhantes, o que pode ter ocorrido em função da dieta usada, que foi de alto concentrado e fornecida restritamente. Outro fator associado a esta característica pode estar relacionado à precocidade do Nelore em depositar gordura.

A taxa de deposição de proteína aumentou com o aumento de ganho de peso diário, o que está de acordo com Geay (1984). No entanto, o autor considerou ainda que com o aumento do peso vivo, o incremento foi menor e diminuiu acentuadamente com o aumento da taxa de ganho.

A composição do corpo vazio encontrada por Putrino (2002) com novilhos Nelore alimentados com 20,40, 60 ou $80 \%$ de concentrado foi de 60,12 a $61,13 \%$ de água, 16,84 a $18,18 \%$ de extrato etéreo, de 17,43 a 17,74\% de proteína e de 4,27 a $4,34 \%$ de cinzas. Considerando que as diferentes quantidades de concentrado promovem diferentes taxas de ganho médio diário (GMD), os dados deste trabalho foram semelhantes aos de Putrino (2002).

Segundo Wright e Russel (1991), que avaliaram novilhos alimentados restritamente ou não, os animais que receberam alimentação restrita apresentaram menores concentrações de gordura e energia e maior concentração de proteína e água no corpo vazio.

Os dados deste trabalho são semelhantes aos do trabalho com novilhos Nelore, desenvolvido por Leme et al. (1994). Os autores observaram a seguinte composição do corpo vazio: $59,6 \%$ de água, $17,9 \%$ de extrato etéreo, $17,9 \%$ de proteína e $4,4 \%$ de cinzas.

As taxas de deposição para tourinhos Santa Gertrudes com 9 meses de idade observadas por Leme et al. (2000) estiveram entre 50,55 a 55,32\% para água, 19,32 a $24,41 \%$ para extrato etéreo, 18,66 a 20,86\% para proteína, 4,02 a 4,50\% para cinzas e 2,978 a 3,467 Mcal/kg para energia. Estes dados indicam que pode haver diferenças entre raças, já que são diferentes dos valores encontrados neste trabalho para Nelore.

Valores mínimos e máximos observados para a taxa de deposição dos componentes químicos corporais e a composição do ganho de peso vazio estão na Tabela 8. 
Tabela 8 - Valores mínimos e máximos para taxa de deposição dos componentes químicos corporais e composição do ganho de peso vazio

\begin{tabular}{lcccccc}
\hline \multirow{2}{*}{ Característica } & \multicolumn{6}{c}{ Tratamentos } \\
\cline { 2 - 7 } & \multicolumn{5}{c}{ T60 } & \multicolumn{5}{c}{ T75 } \\
\cline { 2 - 7 } & Min. & Máx. & Min. & Máx. & Min. & Máx. \\
\cline { 2 - 7 } Água, kg/dia & 0,037 & 0,260 & 0,112 & 0,447 & 0,232 & 0,798 \\
Extrato etéreo, kg/dia & 0,069 & 0,137 & 0,073 & 0,393 & 0,263 & 0,599 \\
Proteína, kg/dia & 0,011 & 0,078 & 0,034 & 0,138 & 0,070 & 0,240 \\
Cinzas, kg/dia & 0,003 & 0,019 & 0,008 & 0,034 & 0,017 & 0,060 \\
\hline & \multicolumn{5}{c}{ Composição do ganho de peso vazio } \\
\cline { 2 - 7 } & Min. Máx. & Min. & Máx. & Min. & Máx. \\
\hline \% Água & 20,59 & 58,93 & 22,07 & 57,38 & 31,97 & 52,27 \\
\% Extrato etéreo & 18,94 & 71,68 & 21,07 & 69,64 & 28,10 & 56,03 \\
\% Proteína & 6,20 & 17,73 & 6,64 & 17,26 & 9,62 & 15,73 \\
\% Cinzas & 1,54 & 4,40 & 1,65 & 4,29 & 2,39 & 3,90 \\
\hline
\end{tabular}

Os valores máximos e mínimos da taxa de deposição dos componentes do corpo e da composição do ganho de peso vazio dão uma idéia das diferenças nas respostas individuais a cada tratamento, aos quais os animais são submetidos.

Para a comparação de dados em bases diferentes e para as estimativas e predições do desempenho animal foi calculada a relação entre peso do corpo vazio (PCVz) e peso vivo em jejum (PVj) e entre ganho de peso de corpo vazio (GPCVz) e ganho de peso vivo em jejum (GPVj).

Os valores encontrados neste experimento foram de 0,9852 para a relação ganho de peso vazio : ganho de peso vivo e 0,9514 para peso de corpo vazio : peso vivo. Estes valores foram diferentes daqueles preconizados pelo NRC (1984) que considera que a relação ganho de peso vazio : ganho de peso vivo é 0,956 e peso de corpo vazio : peso vivo é 0,891 .

$\mathrm{Na}$ Tabela 9 estão os valores encontrados para animais zebuínos, em especial o Nelore, por diversos autores.

Tabela 9 - Valores da relação peso de corpo vazio : peso vivo (PCVZ:PVj) e ganho de peso vazio : ganho de peso vivo (GPCVZ:GPVj)

\begin{tabular}{lcccl}
\hline Autor, ano & Concentrado, \% & PCVZ:PVj & GPCVZ:GPVj & Observação \\
\hline Boin et al., 1994a & 40 & - & $0,908-0,954$ & Consumo restrito \\
ou à vontade & \\
Véras et al., 2001b & 25 a 75 & - & 0,964 & Tourinhos Nelore \\
Silva et al., 2002a & - & 0,88 & 0,96 & Vários trabalhos \\
Silva et al., 2002a & 20 a 80 & 0,8975 & 0,96 & Tourinhos Nelore \\
Paulino et al., 2004b & 5 a 65 & 0,8956 & 0,90 & Anelorados \\
Freitas et al., 2006b & 30 a 70 & - & 0,8793 & \\
\hline
\end{tabular}


Os dados encontrados na literatura são diferentes entre si e diferentes deste trabalho, que parece indicar que para novilhos Nelore a relação GPCVZ:GPVj pode ser ligeiramente superior àquela observada pelo NRC (1984) com animais taurinos. No entanto, a maior diferença foi observada para a relação PCVZ:PVj, que pode ter sido influenciada pelo alto teor de concentrado empregado na dieta de todos os tratamentos deste trabalho, enquanto os demais trabalhos usaram diferentes quantidades de concentrado em suas dietas.

\subsubsection{Digestibilidade da dieta}

A digestibilidade da dieta foi alterada pelos tratamentos $(P=0,064)$ e apresentaram os seguintes valores $\mathrm{T} 60=78,76 \%$, T75 $=77,76 \%$ e TAL $=73,94 \%$, que estão representados na Figura 4.

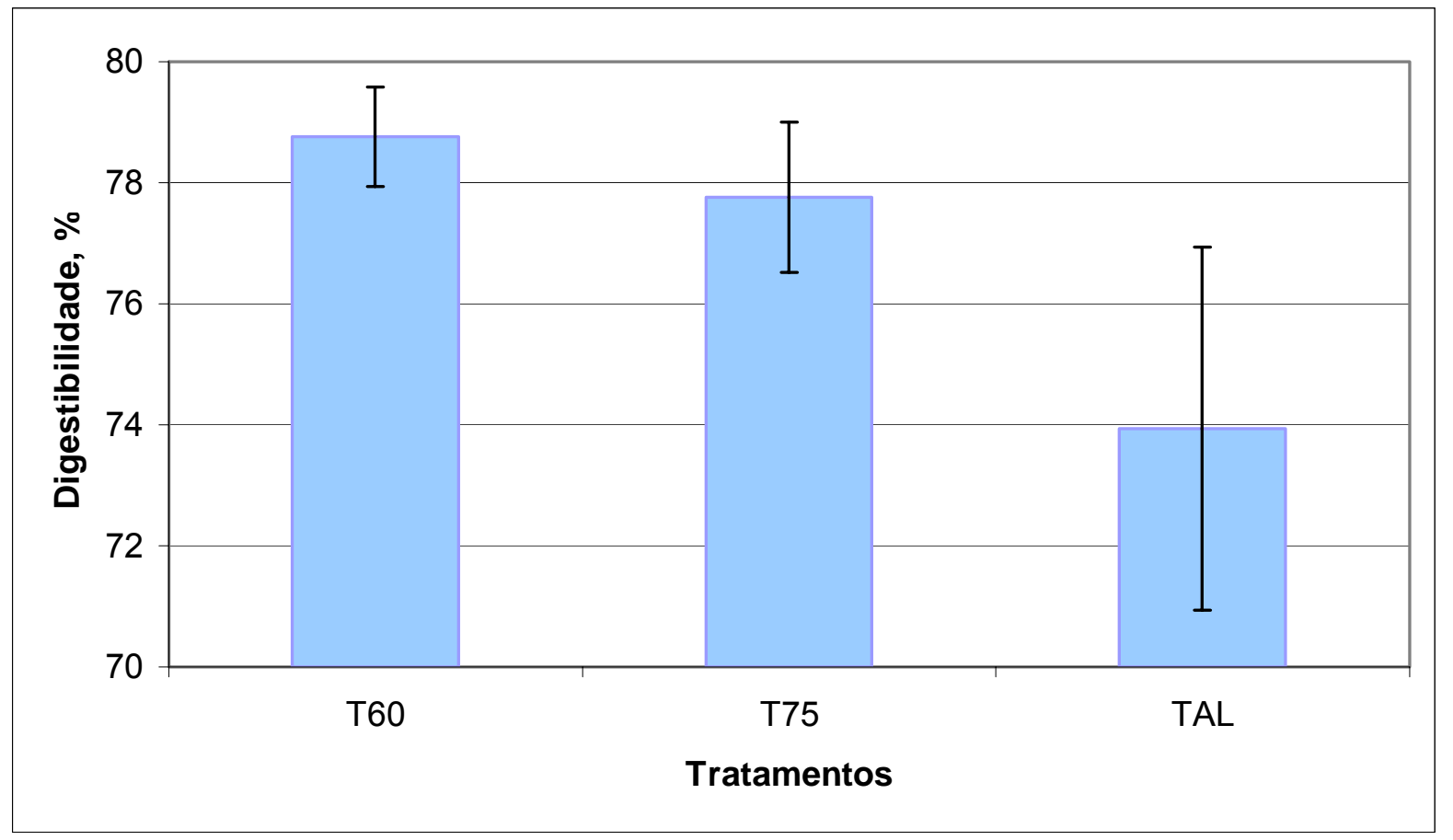

Figura 4 - Digestibilidade das dietas (\%)

A digestibilidade da dieta por novilhos em crescimento, que tiveram diferentes taxas de ganho de peso antes do confinamento, foi estudada por Hersom et al. (2003) que observaram valores crescentes, de 71,1 a $82,8 \%$ de digestibilidade 
da matéria orgânica, com o passar do tempo de confinamento. No entanto, os autores não observaram diferenças entre os tratamentos com alto ou baixo concentrado na dieta.

Diferenças no coeficiente de digestibilidade da matéria seca para animais em restrição alimentar também foram observadas por Fiems et al. (2007), apesar dos valores serem relativamente baixos. Estes autores estudaram o efeito da restrição energética sobre a digestibilidade, em vacas da raça Belgian Blue, encontrando valores que variaram de 59,2 a 61,7\%, para animais comendo à vontade até aqueles com restrição de $70 \%$ na ingestão de energia.

Os valores de digestibilidade da matéria seca observados nesta fase de restrição alimentar ficaram dentro do esperado, variando entre os tratamentos e estando próximos aos valores relatados por outros autores.

\subsubsection{Determinação das exigências de energia e proteína}

A partir da composição do corpo vazio dos animais foi determinada a quantidade de energia retida. A diferença entre a energia metabolizável ingerida e a energia retida foi considerada como sendo a produção de calor dos animais. A equação de regressão entre o logaritmo da produção de calor e a ingestão de energia metabolizável foi:

$\log P C=1,86794 \pm 0,00745+0,00207 \pm 0,00004$ IEM, $R^{2}=0,99$ e $S_{y \cdot x}=0,0114$.

Portanto, a exigência de energia líquida para mantença determinada pelo antilogaritmo do intercepto da equação de regressão foi $74 \mathrm{kcal} / \mathrm{kg} P C V Z^{0,75}$ ou 70 $\mathrm{kcal} / \mathrm{kg} \mathrm{PV}{ }^{0,75}$. Aproximadamente 9,09\% menor que as $77 \mathrm{kcal} / \mathrm{kg} \mathrm{PV}^{0,75}$ encontradas por Lofgreen e Garrett (1968) e preconizadas pelo NRC (1996) e 3,18\% menor que as $72,3 \mathrm{kcal} / \mathrm{kg} \mathrm{PV}{ }^{0,75}$ encontradas por Valadares Filho et al. (2006).

A seguir são apresentados resultados de alguns trabalhos que são divergentes quanto à hipótese de que animais Nelore têm menor exigência que os taurinos. Em trabalho com zebuínos, Boin e Moura (1977) observaram exigência de energia menor que ARC e NRC.

A equação de regressão para o Log PC encontrada por Gonçalves et al. (1991a) para animais Nelore teve como intercepto 1,7765 e coeficiente de 0,0022, 
com $\mathrm{R}^{2}$ de 0,75 . Estes dados indicaram ELm de 59,77 kcal/kg PV $\mathrm{PV}^{0,75}$. Os autores não verificaram diferenças entre grupos genéticos para ELm e ELg.

Em outro trabalho, Boin (1995) encontrou ELm de $78 \mathrm{kcal} / \mathrm{kg} \mathrm{PCVZ}^{0,75}$ para Nelore castrados e $70 \mathrm{kcal} / \mathrm{kg} \mathrm{PCVZ}^{0,75}$ para Nelore inteiro. Por outro lado, Tedeschi et al. (2002) encontraram $77,2 \mathrm{kcal} / \mathrm{kg} \mathrm{PCVZ}{ }^{0,75}$, sem diferenças entre animais inteiros e castrados.

Diferenças nos valores também são observadas nos trabalhos mais recentes como o de Silva et al. (2002a) que encontraram $71,30 \mathrm{kcal} / \mathrm{kg} \mathrm{PCVZ} \mathrm{P}^{0,75}$ para animais zebuínos, 11,8\% inferior à recomendada pelo NRC (1996) e o de Silva et al. (2002b)

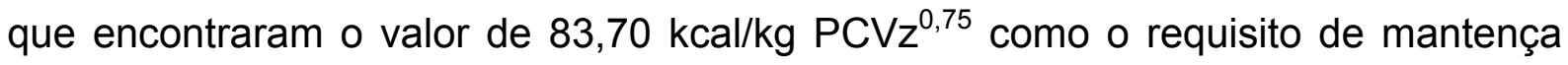
para animais não castrados pertencentes à raça Nelore.

Freitas et al. (2006a) encontraram o valor de $79 \mathrm{kcal} / \mathrm{kg} \mathrm{PV}{ }^{0,75}$ para Nelore inteiros e cruzados, discordando da hipótese de que os zebuínos têm menor exigência de mantença que taurinos e seus cruzamentos e Chizzotti et al. (2007) encontraram exigência de energia líquida para mantença de novilhos cruzados Nelore $x$ Red Angus de 71,2 kcal/kg PCV ${ }^{0,75}$, que os autores consideraram menores que as preconizadas para animais taurinos.

Apesar da maior parte dos dados indicarem que não há diferença na exigência de ELm entre zebuínos e taurinos, este trabalho confirma a hipótese do NRC de que a exigência de energia líquida de zebuínos é menor.

A equação para estimar o coeficiente e intercepto da equação de predição de energia retida $(E R)$ foi:

$\log E R\left(k g / P C V Z^{0,75}\right)=-1,30980 \pm 0,02236+(0,85848 \pm 0,05780 * \log G P C V Z), R^{2}$ $=0,89$ e $S_{y \cdot x}=0,09927$.

Os valores desta equação foram diferentes da equação adotada pelo NRC (1984) onde ER = -1,197 + 1,097 * Log GPCVZ.

Com os dados da equação de Log ER foi possível determinar a equação para predição da energia líquida para ganho de peso em função do ganho de peso de corpo vazio e do peso do corpo vazio que foi:

$\mathrm{ER}=0,0467{ }^{*} \mathrm{PCVZ}^{0,75 *} \mathrm{GPCVZ}^{0,8585}$.

No mesmo sentido a equação do NRC (1984) foi ER $=0,0667$ * $P C V Z Z^{0,75}$ * GPCVZ ${ }^{1,097}$. As equações encontradas para animais Nelore foram determinadas por Véras et al. (2001b) que encontraram a equação $E R=0,044$ * $P C V z^{0,75}$ * GPCV $z^{1,1578}$, por Silva et al. (2002a) que encontraram a equação ELg = 0,0435 * 
$P C V z^{0,75}$ * $G P C V z^{0,8241}$ e também por Silva et al. (2002b) que encontraram a equação $E L g=0,0413 *{ }^{*} \mathrm{PCV}^{0,75}$ * $\mathrm{GPCV} z^{0,978}$.

A equação deste trabalho foi semelhante às encontradas por Silva et al. (2002a) e Silva et al. (2002b) e pode indicar menor exigência para ganho de peso.

Os dados gerados por meio da equação deste trabalho estão apresentados na Tabela 10.

Tabela 10 - Exigência diária de energia líquida (Mcal) para mantença e para diferentes taxas de ganho diário de peso de corpo vazio $(\mathrm{kg} / \mathrm{dia})$ em função do peso vivo em jejum ou peso do corpo vazio (PCVZ)

\begin{tabular}{|c|c|c|c|c|c|}
\hline \multirow{3}{*}{ Peso vivo } & \multirow{3}{*}{ PCVZ } & \multirow{3}{*}{$E L_{m}$} & \multicolumn{3}{|c|}{$\mathrm{EL}_{g}$} \\
\hline & & & & GPCVZ & \\
\hline & & & 0,250 & 0,700 & 1,100 \\
\hline 350 & 329 & 5,42 & 1,10 & 2,66 & 3,92 \\
\hline 375 & 354 & 5,71 & 1,16 & 2,80 & 4,13 \\
\hline 400 & 378 & 5,99 & 1,22 & 2,95 & 4,35 \\
\hline 425 & 403 & 6,27 & 1,28 & 3,09 & 4,56 \\
\hline 450 & 428 & 6,55 & 1,34 & 3,23 & 4,77 \\
\hline
\end{tabular}

Os valores diários de energia líquida para um quilo de ganho de peso para novilhos de 350 a $450 \mathrm{~kg}$ PV recomendados pelo NRC (1996) foram 4,13 a 4,99 Mcal, por Valadares Filho et al. (2006) foram 4,20 a 5,07 Mcal e deste trabalho foram 3,61 a 4,39 Mcal.

As exigências diárias de energia líquida para ganho, observadas por Boin (1995) para animais de 325 a $425 \mathrm{~kg}$ de PCVz foram de 1,95 a 2,38 Mcal para ganho de 0,400 kg de GPCVz e de 5,37 a 6,56 Mcal para 1,0 kg de GPCVz.

As exigências de energia líquida para ganho, observadas por Freitas et al. (1994a) para animais de 350 a $450 \mathrm{~kg}$ de PV foram 3,48 a 3,94 Mcal, valores estes, mais próximos aos encontrados neste trabalho. Por outro lado, Estrada et al. (1994) não encontraram diferenças entre grupos genéticos para exigência de $\mathrm{EL}_{\mathrm{g}}$.

Os resultados encontrados por Ferrell e Jenkins (1998) não confirmam a hipótese de que a mantença de animais cruzados de raças tropicais adaptadas ou zebuínos (Boran, Brahman) é menor que os requerimentos de mantença de taurinos durante o confinamento. No entanto, os autores ressaltam que o confinamento ocorreu durante o período de inverno, quando a temperatura ambiente foi mais baixa, o que poderia elevar a necessidade de energia para os animais. 
Os valores de exigência líquida diária de energia para mantença encontrados por Silva et al. (2002b) para tourinhos Nelore variaram de 6,25 a 7,54 Mcal/dia para peso vivo de 350 a $450 \mathrm{~kg}$.

Embora trabalhando com animais cruzados a pasto, Fontes et al. (2005b) encontraram valores inferiores aos recomendados pelo NRC (1996) para energia líquida de mantença, que variaram de 3,98 a 6,18 Mcal/dia para animais de PCVz de 250 a $450 \mathrm{~kg}$.

As exigências de energia para GPCVz observadas por Freitas et al. (2006b) para tourinhos Nelore e cruzados, na faixa de peso de 350 a $450 \mathrm{~kg}$ de PV, estiveram entre 4,2 a 4,7 Mcal/kg GPCVz.

Embora não sendo exatamente igual aos dados encontrados na literatura, a exigência de energia líquida para ganho de peso encontrada neste trabalho ficou dentro do intervalo dos dados publicados para Nelore e cruzados, sendo menores que os valores indicados pelo NRC (1996) e Valadares Filho (2006).

A concentração de energia no peso do corpo vazio e por quilo de ganho de peso do corpo vazio estão na Tabela 11.

Tabela 11 - Concentração de energia (Mcal/kg) depositada no corpo vazio e no ganho de um quilo em peso de corpo vazio

\begin{tabular}{lccc}
\hline \multirow{2}{*}{ Característica } & \multicolumn{3}{c}{ Tratamentos } \\
\cline { 2 - 4 } & T60 & T75 & TAL \\
\hline Peso corpo vazio & 1,21 & 2,80 & 5,31 \\
Ganho peso de corpo vazio & 4,42 & 4,29 & 4,52 \\
\hline
\end{tabular}

A concentração de energia por kg PCVZ encontrada por Fontes (1995) para novilhos Nelore de 200 a $400 \mathrm{~kg} \mathrm{PCVz}$ foi de 1,18 a 3,51 Mcal/kg PCVz e para GPCVz foi de 3,03 a 9,02 Mcal/kg GPCVz.

As concentrações de energia por kg PCVz observadas por Véras et al. (2001b) foram de 2,23 a 2,56 Mcal/kg PCVz para tourinhos Nelore de 300 a $450 \mathrm{~kg}$ de PV e de 2,89 a 3,31 Mcal/kg GPCVz para os mesmos animais.

Silva et al. (2002b) observaram que a concentração de energia aumentou de 2,39 para 2,81 Mcal/kgPCVz com a elevação do peso vivo de 200 para $450 \mathrm{~kg}$ e a concentração de proteína diminuiu de 198,5 para 186,5 g/kg PCVz.

Portanto, os valores para concentração de energia observados neste trabalho estão dentro da amplitude de valores da literatura. 
A eficiência de uso da energia metabolizável para ganho de peso ou $\mathrm{k}_{\mathrm{g}}$ foi calculada segundo Valadares Filho et al. (2006). A equação de regressão entre a energia retida diariamente por quilo de peso metabólico e a ingestão diária de energia metabolizável (IEM) por quilo de peso metabólico foi:

$E R=-0,03200 \pm 0,00803+0,33492 \pm 0,03954$ * IEM, $R^{2}=0,69$ e $S_{y \cdot x}=0,01235$

Então, considerando o coeficiente de inclinação da reta como a eficiência de utilização da energia para ganho de peso ou $\mathrm{k}_{\mathrm{g}}$ encontra-se, por meio da equação de ER acima, o valor de 0,33.

Este valor foi menor que o recomendado por Valadares Filho et al. (2006). Estes autores encontraram valor de $\mathrm{k}_{\mathrm{g}}$ de 0,35 para taxas de ganho de peso menores que $1,0 \mathrm{~kg} /$ dia e observaram $\mathrm{k}_{\mathrm{g}}=0,47$ para taxas de ganho de peso maiores ou iguais a $1,0 \mathrm{~kg} / \mathrm{dia}$, com dietas contendo mais que $50 \%$ de concentrado. Portanto, pode-se inferir que a taxa de ganho de peso é determinante na eficiência, uma vez que os animais deste trabalho foram alimentados com dieta com $80 \%$ de concentrado, mas com consumo limitado, o que proporcionou baixas taxas de ganho diário.

O valor médio de $\mathrm{k}_{\mathrm{g}}$ encontrado por Boin et al. (1994b) foi 0,34 e Silva et al. (2002a) encontraram $\mathrm{k}_{\mathrm{g}}$ de 0,33 , para dieta com 69,91\% de NDT.

Valores mais altos foram encontrados por Fontes et al. (2005a) que encontraram $k_{g}$ de 0,37 para animais Gir-Holandês mantidos em pastagem e por Freitas et al. (2006c) que encontraram $\mathrm{k}_{\mathrm{g}}$ de 0,40 para tourinhos Nelore puros e cruzados alimentados com quantidades crescentes de concentrado de 30 a $70 \%$ da MS.

Os valores de $\mathrm{k}_{\mathrm{g}}$ dos trabalhos nacionais são bem próximos e o valor encontrado neste trabalho não foi diferente destes valores.

As exigências líquidas de proteína e de proteína metabolizável estão na Tabela 12.

Tabela 12 - Exigências de proteína líquida e metabolizável por quilo de peso de corpo vazio (kg PCVZ) e por quilo de ganho de peso de corpo vazio (GPCVZ)

\begin{tabular}{lccc}
\hline \multirow{2}{*}{ Característica } & \multicolumn{3}{c}{ Tratamentos } \\
\cline { 2 - 4 } & 1760 & $\mathrm{~T} 75$ & $\mathrm{TAL}$ \\
\hline Proteína líquida g/kgPCVZ & 178,32 & 177,20 & 174,15 \\
Proteína líquida g/GPCVZ & 134,12 & 132,50 & 125,74 \\
Proteína metabolizável g/kgPCVZ & 362,44 & 360,16 & 353,96 \\
Proteína metabolizável g/GPCVZ & 272,60 & 269,31 & 255,58 \\
\hline
\end{tabular}


Estudando a exigência de proteína para novilhos de cinco grupos genéticos, Gonçalves et al. (1991b) concluíram que os grupos diferem quanto à necessidade deste nutriente, encontrando valores de proteína líquida de 143 a 124 g/kg GPCVz para os Nelore de 350 a $450 \mathrm{~kg}$ de peso vazio. Para concentração de proteína líquida, Freitas et al. (1994b) encontraram valores de 0,17 a 0,19 kg/kg de PCVZ para tourinhos Nelore.

Os valores de concentração de proteína (g) por quilo de aumento de PCVz observados por Boin (1995) para Nelore castrados de $350 \mathrm{~kg}$ de PCVz variaram de 160 a $120 \mathrm{~g} / \mathrm{kg}$ GPCVz para GPCVZ de 0,157 a 0,776 kg e de 136 a $121 \mathrm{~g} / \mathrm{kg}$ GPCVz para GPCVz de 0,420 a 1,022 kg.

Em trabalho com tourinhos Nelore Véras et al. (2001b) encontraram valores de 202,20 a 180,56 g/kg PCVz para peso vivo variando de 300 a $450 \mathrm{~kg}$ e de 152,07 a $135,80 \mathrm{~g} / \mathrm{kg}$ GPCVz.

Putrino (2002) encontrou concentração de proteína de $176 \mathrm{~g} / \mathrm{kg} \mathrm{PCVz}$, que foi maior que o valor observado para os animais Brangus (156 g/kg PCVz) pesquisados pela autora.

Segundo Silva et al. (2002), o NRC (1996) subestima as exigências dietéticas de PB para animais zebuínos com mais de $300 \mathrm{~kg}$ de PV.

As exigências líquidas de proteína para GPCVz encontradas por Paulino et al. (2004b) decresceram à medida que o peso vivo dos animais se elevaram e variaram de 129,01 a 106,84 g/kg GPCVz para animais com peso vivo de 250 a $400 \mathrm{~kg}$.

A exigência líquida de proteína para GPCVz observadas por Freitas et al. (2006b) para tourinhos Nelore e cruzados, na faixa de peso de 350 a $450 \mathrm{~kg}$ de PV, variou de 148 a $143,5 \mathrm{~g} / \mathrm{kg}$ GPCVZ.

Os dados de exigência de proteína líquida para ganho observados neste trabalho ficaram entre os extremos observados na literatura. E, são superiores aos recomendados por Valadares Filho et al. (2006).

Para cálculo da exigência de proteína metabolizável em gramas por quilo de peso metabólico foi usada a metodologia de Wilkerson et al. (1993) e a equação obtida pela regressão entre a ingestão de proteína metabolizável (PM) (g/dia) e o ganho médio diário (GMD) (kg/dia) foi:

$P M=371,68 \pm 35,72+335,74 \pm 42,46 * G M D, R^{2}=0,68 ; S_{y \cdot x}=102,98$. 
Portanto, fazendo a divisão do intercepto pelo peso médio metabólico dos animais, segundo o proposto por Wilkerson et al. (1993), encontra-se o valor de 4,32. Neste caso, a exigência de proteína metabolizável para mantença seria 4,32 * $\mathrm{PV}^{0,75}$. Na Tabela 13 estão as exigências para a faixa de peso deste experimento, considerando-se o valor de 3,8 proposto por Wilkerson et al. (1993) e adotado pelo NRC (1996), o valor de 4,0 encontrado por Valadares Filho et al. (2006) e 4,32 deste trabalho.

Tabela 13 - Exigência de proteína metabolizável (g/dia) para mantença segundo o valor encontrado por Wilkerson et al. (1993), Valadares Filho et al. (2006) e deste experimento - Aferri (2007)

\begin{tabular}{lllccc}
\hline Peso vivo & PCVZ & PV $^{0,75}$ & Wilkerson & Valadares $F^{\circ}$ & Aferri \\
\hline 350 & 329 & 77 & 293,59 & 309,04 & 333,76 \\
375 & 354 & 82 & 309,92 & 326,23 & 352,33 \\
400 & 378 & 86 & 325,97 & 343,13 & 370,58 \\
425 & 403 & 90 & 341,76 & 359,75 & 388,53 \\
450 & 428 & 94 & 357,31 & 376,12 & 406,20 \\
\hline
\end{tabular}

O valor observado por Valadares et al. (1997) para exigência de proteína metabolizável para mantença determinado por balanço de nitrogênio foi de $4,13 \mathrm{~g} / \mathrm{kg}$ $\mathrm{PV}^{0,75} /$ dia, menor que o observado neste trabalho, mas sendo também acima do valor preconizado por Valadares Filho et al. (2006) para as condições do Brasil, que é de 4,0 * $\mathrm{PV}^{0,75}$. No entanto, estes valores indicam que a exigência de proteína para zebuínos, especialmente o Nelore, estão acima do valor sugerido por Wilkerson et al. (1993) e pelo NRC (1996) de 3,8 ${ }^{*} \mathrm{PV}^{0,75}$ e por Susmel et al. (1993) de 3,88 * $\mathrm{PV}^{0,75}$.

As exigências de proteína metabolizável para ganho de peso foram de 273, 269 e $256 \mathrm{~g} / \mathrm{kg}$ de ganho de peso vazio para os tratamentos T60, T75 e TAL, respectivamente. A média foi de $266 \mathrm{~g} / \mathrm{kg}$ de ganho de peso vazio. A queda na exigência com o aumento da taxa de ganho de peso ficou dentro do esperado.

Wilkerson et al. (1993) encontraram exigência de proteína metabolizável para ganho de peso de $305 \mathrm{~g} / \mathrm{kg}$ de ganho de peso vivo.

Os valores do NRC (1996) ficaram entre 298 e 246 g/d de proteína metabolizável para novilhos de 350 a $450 \mathrm{~kg}$ de PV.

Os dados deste trabalho estimaram a exigência de proteína metabolizável para ganho, considerando um animal de $450 \mathrm{~kg}$, como sendo $8 \%$ superior ao valor recomendado pelo NRC (1996), sendo igual ao encontrado por Silva et al. (2002b). 


\subsubsection{Perfil hormonal e parâmetros sanguíneos}

5.1.5.1 Concentração plasmática de IGF-I, T3 e T4

A concentração plasmática de IGF-I não foi diferente entre os tratamentos $(P=0,146)$, apresentando as seguintes médias $487,91 \pm 31,20$ para $T 60,463,05 \pm$ 31,20 para T75 e 401,80 \pm 31,20 para TAL.

A concentração plasmática de IGF-I apresentou efeito linear $(P<0,001)$ no tempo, $Y=323,18+4,1183 X$. Os dados estão demonstrados na Figura 5.

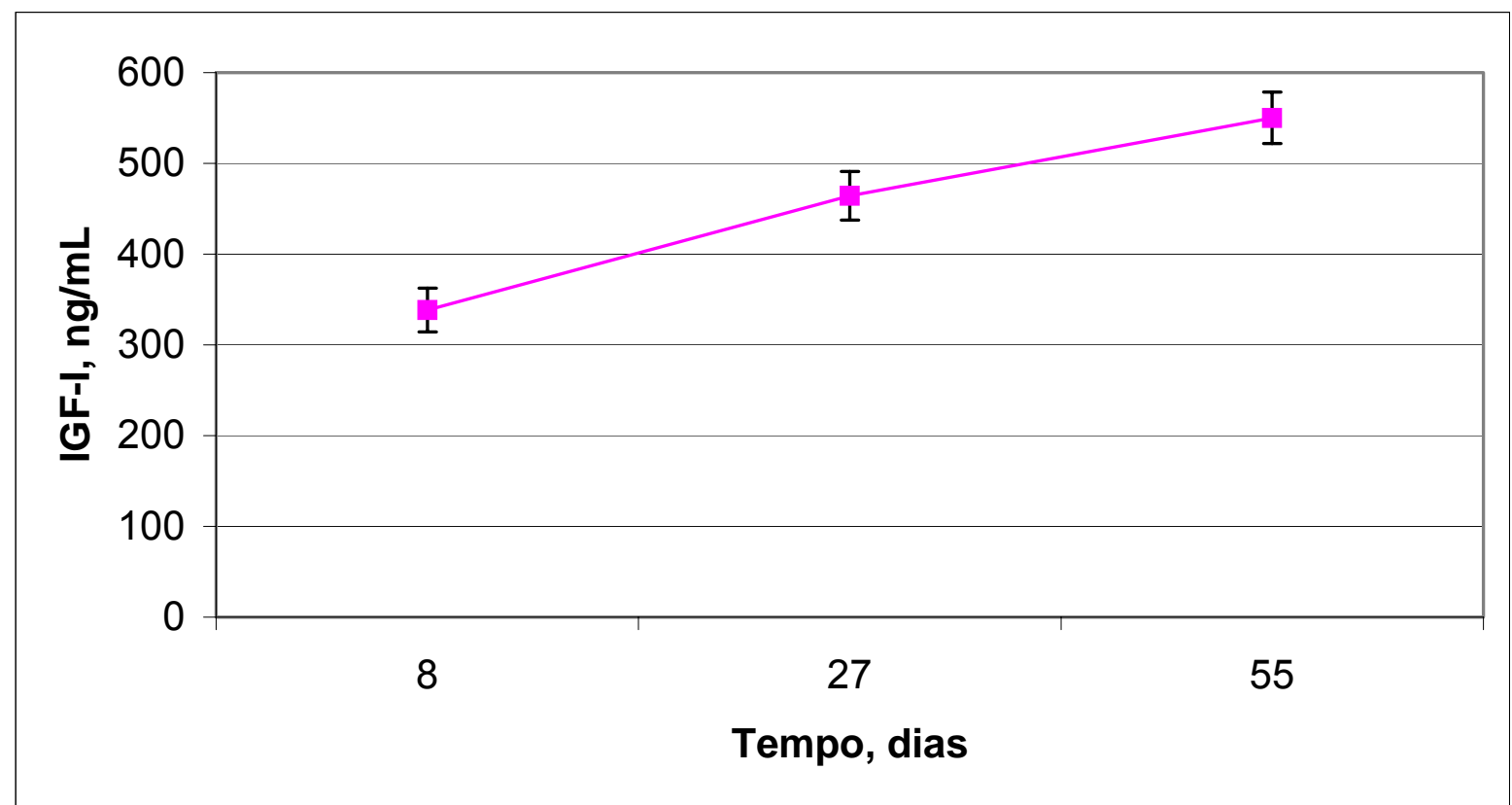

Figura 5 - Concentração média dos tratamentos para IGF-I nos dias 8, 27 e 55 de confinamento

Os valores de IGF-I comportaram-se de forma diferente daqueles observados por Ellenberger et al. (1989) em trabalho com novilhos em crescimento normal ou com $350 \mathrm{~g}$ de ganho médio diário. Estes autores observaram que o nível de IGF-I diminuiu para os animais em crescimento mais lento. Este mesmo comportamento dos dados foi observado por Hayden et al. (1993), Hornick et al. (1998b) e Lima (2005). 
Essa inversão na concentração do IGF-I pode estar associada ao fato de que a restrição no crescimento ocorreu por um período pequeno de tempo, 58 dias. Outro ponto a ser considerado é que a restrição alimentar foi quantitativa e não qualitativa, o que permitia o desenvolvimento dos animais, especialmente a deposição de proteína, já que o crescimento ósseo não era acelerado, em função da idade dos animais, e a taxa de ganho de peso não favorecia a deposição de gordura.

Ainda que não tenham sido observadas diferenças entre os tratamentos, o aumento linear nas concentrações de IGF-I no tempo pode indicar que houve menor taxa de crescimento ao longo do confinamento para os tratamentos T60 e T75, pois segundo Scanes (2003), existe correlação negativa entre a concentração de IGF-I circulante e a taxa de crescimento. Este autor cita também, que a temperatura e a umidade exercem influência sobre as concentrações de IGF-I e que, embora possa ter outros fatores envolvidos, talvez haja diferenças entre raças.

Foi observada interação entre tratamento e tempo $(P=0,006)$ para a concentração plasmática de T3. Os tratamentos T60 $(P<0,001)$ e T75 $(P=0,015)$ apresentaram comportamento linear, descrito pelas equações: $\mathrm{Y}_{\mathrm{T} 60}=96,3456+$ $2,3919 \mathrm{X}$ e $\mathrm{Y}_{\mathrm{T} 75}=117,56+1,5605 \mathrm{X}$. No tratamento $\mathrm{TAL}(\mathrm{P}=0,045)$ o efeito foi quadrático, onde $\mathrm{Y}_{\mathrm{TAL}}=170,25-2,5395 \mathrm{X}+0,04871 \mathrm{X}^{2}$. Os dados estão representados na Figura 6. 


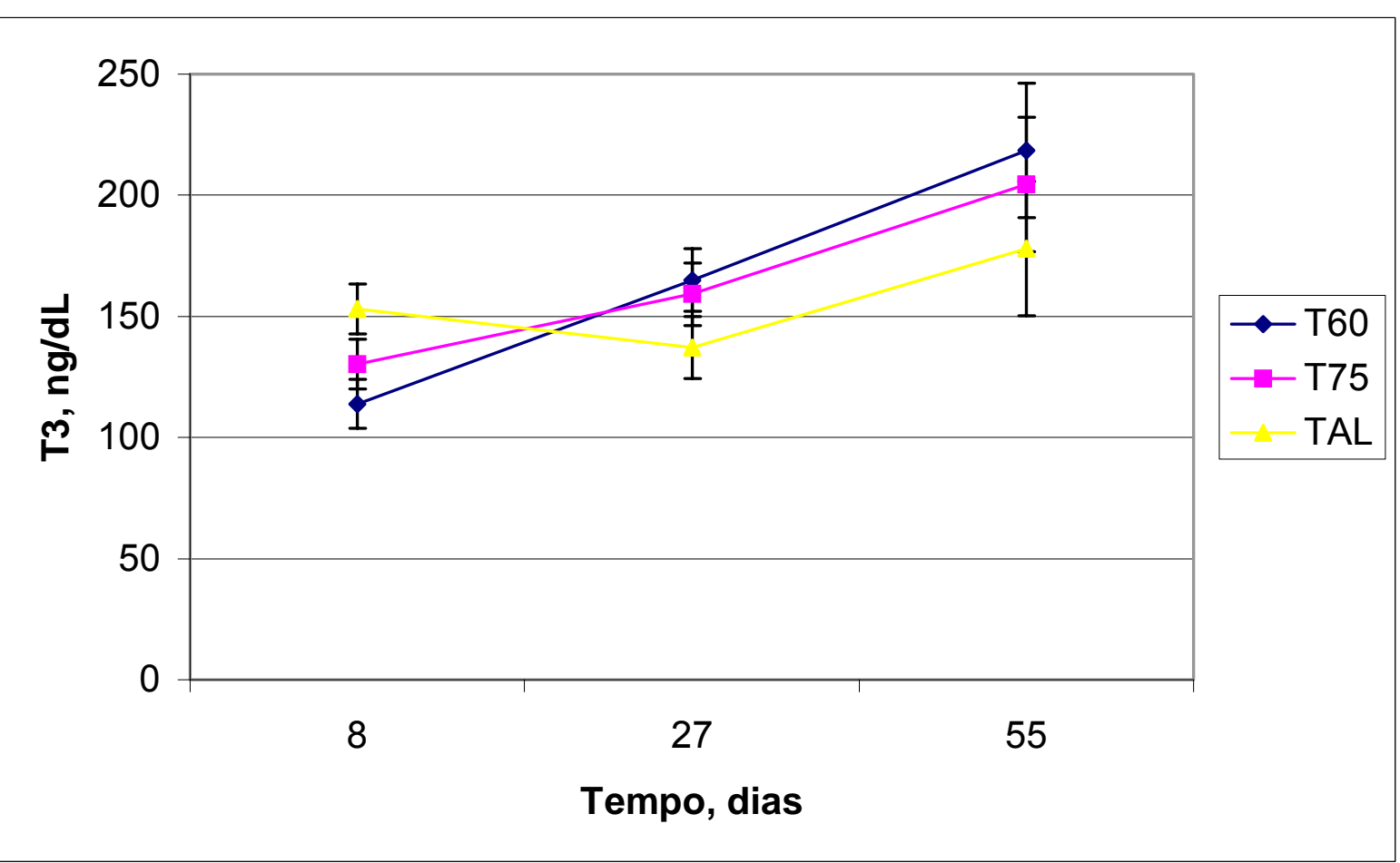

Figura 6 - Concentração plasmática de T3 para os três períodos de colheita

Os animais que estavam passando por restrição na ingestão de alimentos apresentaram aumento na concentração de T3 durante todo o período experimental, contrariamente ao que era esperado.

Segundo Reece (1996), a função melhor conhecida dos hormônios da tireóide é sua habilidade em elevar a temperatura interna e assim aumentar a taxa de consumo de oxigênio. Os hormônios da tireóide estimulam as atividades metabólicas da maioria dos tecidos do corpo, exceto o cérebro, pulmões, retina, testículos e baço. Ainda segundo o autor, o efeito lipolítico da epinefrina é também marcadamente potencializado pelos hormônios da tireóide. O papel específico desses hormônios na elevação da produção de calor interno não foi definitivamente elucidado, mas tem sido cogitado que a elevação do calor é secundária ao incremento na síntese protéica estimulados pelos hormônios da tireóide.

Neste sentido, a elevação na concentração de T3 pode ter ocorrido pela mobilização do tecido gorduroso em favorecimento ao incremento na síntese de proteína, já que houve ganho de peso em tecido magro.

Já no tratamento TAL as concentrações plasmáticas durante o primeiro período apresentaram queda, provavelmente como efeito da maior taxa de ganho de peso na fase inicial de confinamento, e o comportamento quadrático da curva indica que outro fator pode ter influenciado os animais interferindo no equilíbrio hormonal 
no último período. Este fato provavelmente ocorreu pela diminuição na temperatura do ambiente, que ocorreu dias antes da colheita de sangue e que também influenciou outros parâmetros avaliados.

Foi observado efeito linear $(P=0,006)$ para o tempo 8 , apresentando a seguinte equação: $Y_{8}=65,5813+0,8715 X$. Isto poderia indicar que, com oito dias de confinamento, os animais que estavam com ingestão Ad libitum apresentavam elevada taxa de síntese protéica. O comportamento da concentração deste hormônio nos outros dois períodos experimentais reflete os efeitos dos tratamentos (Figura 6).

Ao contrario do que foi observado por Blum et al. (1985), Hayden et al. (1993) e Lima (2005), os valores de T3 se elevaram durante o período de restrição alimentar, fato que pode ter ocorrido em função dos animais estarem com dieta restrita, porém de alto teor de concentrado e com energia disponível para ganho de peso moderado. Outro fator que pode ter levado a valores distintos nos experimentos é o período de restrição, que neste experimento foi menor que 60 dias e nos experimentos citados foram superiores a 100 dias.

De outra forma, Ellenberger et al. (1989) não observaram diferenças entre os valores de T3 para novilhos confinados com consumo restrito ou não, o que pode indicar a multiplicidade de fatores envolvidos com a concentração de T3.

Para a concentração de $T 4$, os tratamentos não foram diferentes $(P=0,843)$ apresentando as médias 15,19 \pm 1,65 para T60, 16,71 \pm 1,65 para T75 e 15,70 \pm 1,65 para TAL, e não houve interação $(P=0,246)$ entre os fatores.

Estes dados são contrários aos observados por Ellenberger et al. (1989), Hayden et al. (1993) e Lima (2005) que observaram queda nas concentrações de T4 para os tratamentos com restrição comparados aos animais sem restrição.

Houve efeito quadrático de tempo $(P=0,021), Y=14,5009+0,2820 x-$ $0,00558 X^{2}$, como pode ser observado na Figura 7 . 


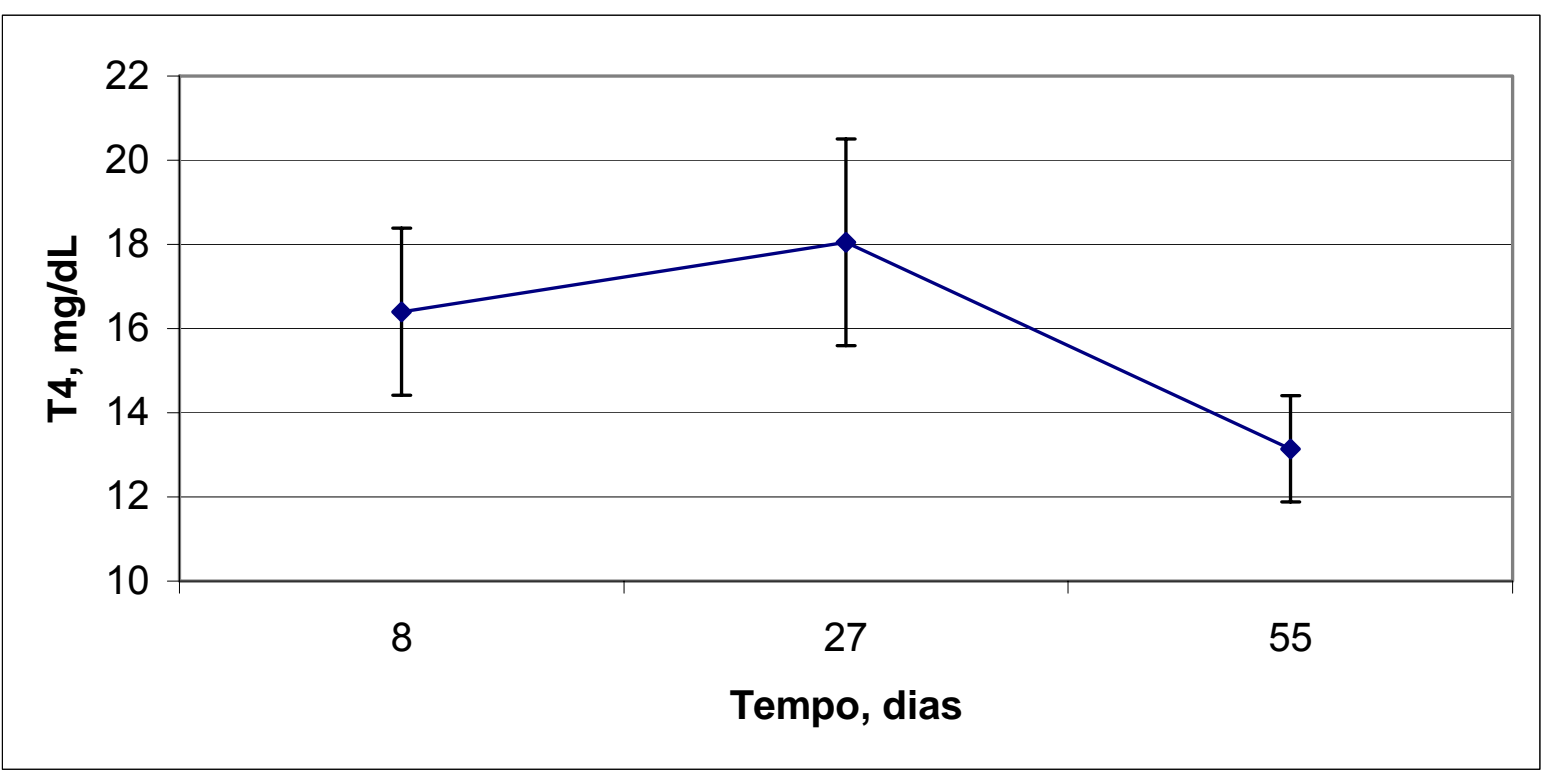

Figura 7 - Concentração média de T4 no tempo de confinamento

Segundo Reece (1996) a excitação e a ansiedade resultam numa diminuição na secreção de hormônios tireóideos porque o estímulo do sistema nervoso simpático, presente nesses estados, causa um aumento na secreção de epinefrina e norepinefrina, resultando num aumento na taxa metabólica e produção de calor. Isto poderia explicar a queda na concentração de T4 no último período, uma vez que os animais terminavam suas refeições no final da manhã e aguardavam até o próximo dia para receberem nova alimentação.

5.1.5.2 Concentração de glicose, proteína total e nitrogênio

Os valores de glicose, apresentados na Tabela 14, não diferiram entre os tratamentos e tempos.

Tabela 14 - Médias dos tratamentos para concentração plasmática de glicose

\begin{tabular}{|c|c|c|c|c|}
\hline \multirow{2}{*}{ Característica } & \multicolumn{3}{|c|}{ Tratamento } & \multirow{2}{*}{$\mathrm{P}$} \\
\hline & T60 & T75 & TAL & \\
\hline \multirow[t]{3}{*}{ Glicose, mg/dL } & $119,95 \pm 9,78$ & $129,23 \pm 9,78$ & $110,29 \pm 9,78$ & 0,399 \\
\hline & \multicolumn{3}{|c|}{ Dias de confinamento } & \\
\hline & 8 & 27 & 55 & \\
\hline
\end{tabular}

\begin{tabular}{lllll}
\hline Glicose, $\mathrm{mg} / \mathrm{dL}$ & $115,47 \pm 5,08$ & $116,56 \pm 4,5$ & $127,44 \pm 11,13$ & 0,504 \\
\hline
\end{tabular}

Em semelhança ao que observamos, encontramos o trabalho de Hornick et al. (1998b). Os valores de glicose observados por estes autores para novilhos de dupla 
musculatura, com ganho de peso de $0,5 \mathrm{~kg} / \mathrm{dia}$ por período de 114 dias, não foi diferente dos animais do tratamento ad libitum.

A ausência de variação significativa no comportamento da glicose ao longo do tempo e nos tratamentos era esperada, visto que, segundo Leek (1996) os produtos finais da fermentação (ácidos graxos voláteis) que os ruminantes absorvem e utilizam como seus substratos metabólicos primários são totalmente diferentes dos produtos finais da digestão (glicose) em não ruminantes.

Nos ruminantes, é necessário uma concentração sangüínea de glicose de 30 a $60 \mathrm{mg} / \mathrm{dL}$ para processos fisiológicos normais (BERGMAN, 1996). No entanto, os valores encontrados foram superiores ao esperado, o que pode ser explicado pela intensa atividade metabólica dos animais que eram jovens, com 20 meses e peso inicial de $320 \mathrm{~kg}$, e estavam em período de crescimento.

Blum et al. (1985) encontraram diminuição nos valores de glicose ao longo do período de confinamento, tanto para animais com consumo livre como para animais em alimentação restrita, sendo a queda destes mais acentuada, indicando possível redução na gliconeogênese.

Em avaliação do nível de glicose em novilhos cruzados Angus Hereford durante período de restrição alimentar, Ellenberger et al. (1989) encontraram diminuição dos valores para o grupo restrito em relação ao grupo ad libitum, sendo estes valores, de 93,3 mg/dL para controle e $84,0 \mathrm{mg} / \mathrm{dL}$ para restrito, inferiores aos que observamos para Nelore.

A concentração de proteína total (PT) não foi diferente entre os tratamentos, mas apresentou diferenças entre os tempos. Os valores estão na Tabela 15.

Tabela 15 - Médias dos tratamentos e dos tempos de confinamento para a concentração de proteína total

\begin{tabular}{|c|c|c|c|c|}
\hline \multirow{2}{*}{ Característica } & \multicolumn{3}{|c|}{ Tratamento } & \multirow{2}{*}{$\mathrm{P}$} \\
\hline & T60 & T75 & TAL & \\
\hline \multirow[t]{3}{*}{ Proteína total, g/dL } & $8,38 \pm 0,29$ & $7,75 \pm 0,29$ & $7,94 \pm 0,29$ & 0,299 \\
\hline & \multicolumn{3}{|c|}{ Dias de confinamento } & \\
\hline & 8 & 27 & 55 & \\
\hline Proteína total, g/dL & $8,79 \pm 0,27_{a}$ & $8,14 \pm 0,37_{b}$ & $7,15 \pm 0,14_{c}$ & $<0,001$ \\
\hline
\end{tabular}

Segundo Canavessi et al. (2000) os fatores sexuais não exerceram influência sobre a proteína total de animais em diferentes faixas etárias. Os autores 
observaram que os valores da proteína total na terceira faixa etária, de 18 a 24 meses, foram superiores aos da segunda faixa etária, de 8 a 18 meses. Os valores observados para os machos de 18 a 24 meses foi de 7,36 $\pm 0,59 \mathrm{~g} / \mathrm{dL}$, semelhante aos valores observados nos tempos 27 e 55 .

Os valores observados com oito dias de confinamento foram mais semelhantes aos dados encontrados por Barbosa et al. (2003) para bovinos mestiços alimentados com capim elefante, cujo valor médio foi de 8,7 $\pm 1,25 \mathrm{~g} / \mathrm{dL}$.

Para novilhas da raça Guzerá, de 18 a 24 meses, Fagliari et al. (1991) encontraram valores estáveis, entre 7,52 e $7,79 \mathrm{~g} / \mathrm{dL}$, durante período de aproximadamente 100 dias de confinamento.

Para a concentração de nitrogênio uréico no plasma (NUP) houve interação $(P \leq 0,001)$ entre os fatores tratamentos e tempo. Os valores são apresentados na Tabela 16.

Tabela 16 - Valores médios de NUP para tratamento e tempo

\begin{tabular}{lcccc}
\hline Tratamento & NUP, $\mathrm{mg} / \mathrm{dL}$ & $\mathrm{EP}$ & $\mathrm{P}$ & Equação \\
\hline T60 & 11,94 & 0,83 & 0,325 & -- \\
T75 & 11,74 & 0,83 & 0,026 & $\mathrm{Y}=9,39+0,069 \mathrm{X}$ \\
TAL & 19,36 & 0,82 & 0,001 & $\mathrm{Y}=18,53-0,32 \mathrm{X}+0,008 \mathrm{X}^{2}$ \\
\hline Tempo & & & & \\
\hline Dia 8 & 13,29 & 0,46 & $<0,001$ & $\mathrm{Y}=59,06-1,33 \mathrm{X}+0,009 \mathrm{X}^{2}$ \\
Dia 27 & 12,67 & 0,51 & $<0,001$ & $\mathrm{Y}=31,99-0,64 \mathrm{X}+0,005 \mathrm{X}^{2}$ \\
Dia 55 & 17,07 & 1,06 & $<0,001$ & $\mathrm{Y}=0,62+0,24 \mathrm{X}$ \\
\hline
\end{tabular}

Os valores de NUP tiveram maior variação quanto mais alto foi o nível de ingestão de alimentos conforme os tratamentos. O efeito quadrático apresentado pelo tratamento TAL deveu-se, provavelmente, ao aumento na ingestão de matéria seca na semana anterior à $3^{\circ}$ colheita de sangue, no dia 29/08/2006, que pode ter ocorrido por ocasião da passagem de uma frente fria que diminuiu a temperatura em aproximadamente $10^{\circ} \mathrm{C}$, como pode ser observado na Figura 8 . 


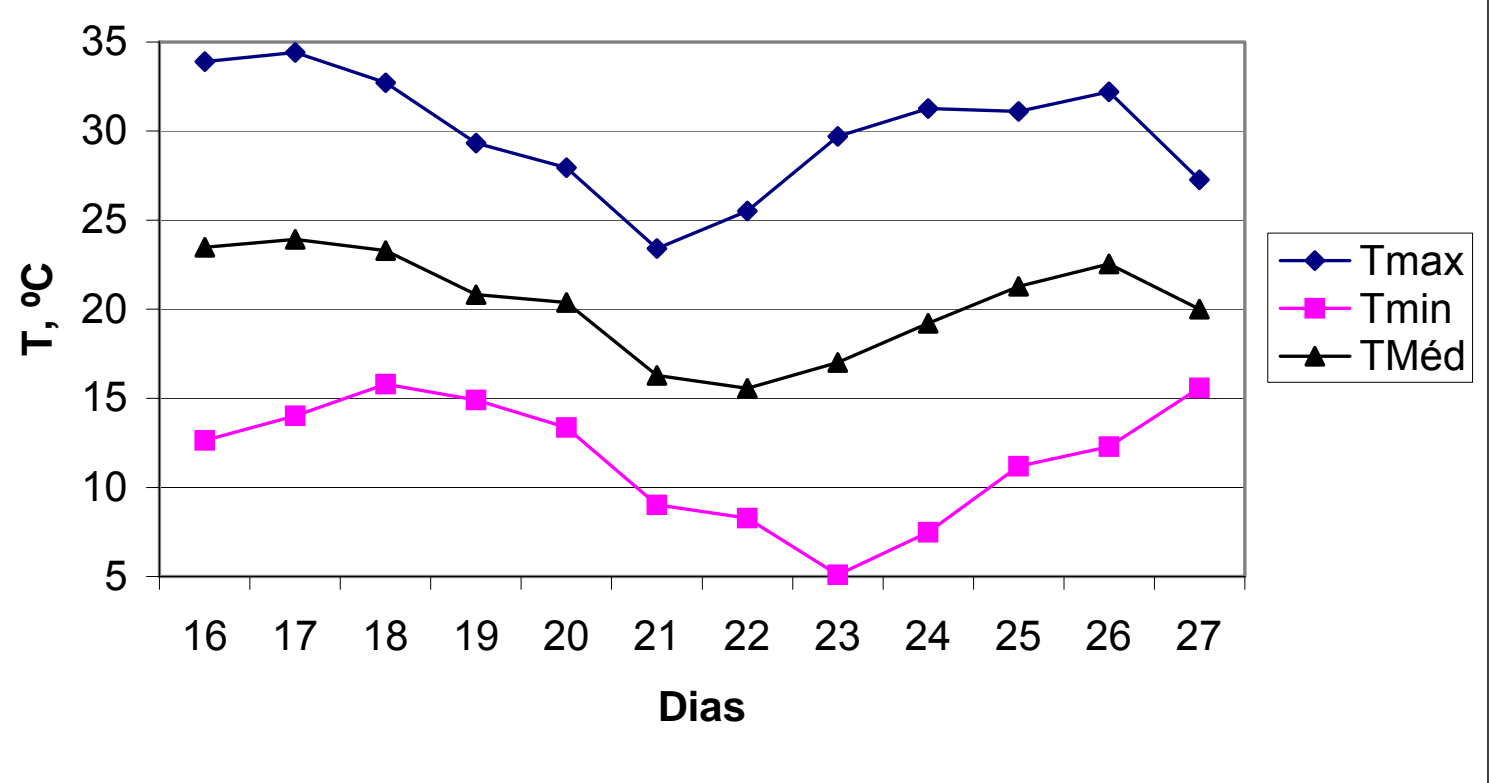

Figura 8 - Temperatura máxima, mínima e média do dia 16 a 27 do mês de agosto de 2006

Este fator climático também pode ter influenciado os outros parâmetros sangüíneos, especialmente a glicose que apresentou aumento numérico na sua concentração.

Os valores de nitrogênio uréico no sangue observados por Ellenberger et al. (1989) para novilhos em restrição $(17,76 \mathrm{mg} / \mathrm{dL})$ não foram diferentes dos animais com alimentação à vontade $(17,98 \mathrm{mg} / \mathrm{dL})$. Eisemann et al. (1993) relataram que no crescimento dos animais, com deposição de tecido magro, há direcionamento do nitrogênio para os tecidos periféricos do corpo, reduzindo a produção de uréia pelo fígado.

Em trabalho com novilhas Nelore e Canchim confinadas, Lanna et al. (1998) observaram valores de NUP de 20 a $31 \mathrm{mg} / \mathrm{dL}$ com dietas contendo 25 ou $45 \%$ de concentrado e bagaço de cana.

Bulle et al. (2002) encontraram valores de NUP de 13,89, 14,12 e 16,29 $\mathrm{mg} / \mathrm{dL}$ para animais alimentados com dietas de 9, 15 e $21 \%$ de bagaço de cana in natura como volumoso. É interessante observar que o maior valor de NUP ocorreu no tratamento com maior quantidade de fibra e que esteve próximo ao valor do TAL que também foi alimentado com dieta contendo mais que $20 \%$ de fibra efetiva.

As médias de NUP para vacas mestiças mantidas a pasto encontradas por Lima et al. (2004) variaram de 7 a $12 \mathrm{mg} / \mathrm{dL}$, valores que os autores consideraram adequados para vacas em lactação. Comparando os valores observados por Lima et 
al. (2004) com aqueles encontrados para os tratamentos com restrição, que estariam numa condição semelhante ao ganho de peso em pastagem, podemos ver que ficaram próximos, aproximadamente $12 \mathrm{mg} / \mathrm{dL}$.

Considerando todos os valores médios de concentração de NUP podemos dizer que estiveram dentro dos limites normais propostos por Swenson (1996), que são de 10 a $30 \mathrm{mg} / \mathrm{dL}$. 


\subsection{Experimento II - Realimentação e ganho compensatório}

Cabe ressaltar que os animais do tratamento "ad libitum" foram alimentados por mais 20 dias após o término do Experimento I, de exigências nutricionais, totalizando um período de 78 dias de confinamento, quando foram abatidos. Os dados deste grupo foram usados para a comparação das características estudadas nesta fase de realimentação. Para esta comparação os animais dos tratamentos que sofreram restrição foram alimentados à vontade por um período de 78 dias e foram abatidos. Desta forma, o critério eleito para a comparação dos tratamentos foi o tempo de confinamento, como se apresenta na Figura 2 do Material e Métodos, embora eles tenham ocorrido em épocas distintas.

\subsubsection{Desempenho}

Os dados de peso vivo em jejum apresentaram interação $(P=0,017)$ entre tempo e tratamento, havendo efeito quadrático para todos os tratamentos ao longo do tempo, como pode ser observado na Tabela 17.

Tabela 17 - Médias do peso vivo em jejum dos tratamentos por tempo de realimentação, valor de $\mathrm{P}$ e equações dos efeitos de tratamento e tempo

\begin{tabular}{lcccccc}
\hline \multirow{2}{*}{ Tratamento } & \multicolumn{4}{c}{ Dia de realimentação } & \multirow{2}{*}{$\mathrm{P}$} & \multirow{2}{*}{ Equação } \\
\cline { 2 - 4 } & 1 & 29 & 57 & 78 & & \\
\hline T60 & $373,87 \mathrm{a}$ & $424,92 \mathrm{a}$ & $463,25 \mathrm{a}$ & $476,33 \mathrm{a}$ & $<0,001$ & $\mathrm{Y}=369,89+2,31 \mathrm{X}-0,012 \mathrm{X}^{2}$ \\
T75 & $400,42 \mathrm{~b}$ & $435,75 \mathrm{a}$ & $475,00 \mathrm{a}$ & $489,17 \mathrm{a}$ & 0,015 & $\mathrm{Y}=394,53+1,78 \mathrm{X}-0,006 \mathrm{X}^{2}$ \\
TAL & $354,71 \mathrm{a}$ & $391,58 \mathrm{~b}$ & $423,84 \mathrm{~b}$ & $442,37 \mathrm{~b}$ & 0,038 & $\mathrm{Y}=352,66+1,49 \mathrm{X}-0,004 \mathrm{X}^{2}$ \\
\hline \multicolumn{2}{l}{ Dia de confinamento } & $\mathrm{P}$ & & Equação \\
\hline 1 & 0,004 & & $\mathrm{Y}=11,64+10,44 \mathrm{X}-0,07 \mathrm{X}^{2}$ \\
29 & & 0,057 & & $\mathrm{Y}=183,53+7,21 \mathrm{X}-0,05 \mathrm{X}^{2}$ \\
57 & 0,041 & & $\mathrm{Y}=189,51+8,19 \mathrm{X}-0,06 \mathrm{X}^{2}$ \\
78 & & 0,052 & $\mathrm{Y}=210,64+7,90 \mathrm{X}-0,06 \mathrm{X}^{2}$ \\
\hline
\end{tabular}

a,b - Letras diferentes na mesma coluna indica diferença significativa.

O efeito quadrático no peso era esperado para todos os animais em confinamento. Esta queda na velocidade de ganho de peso durante a fase de compensação também foi observada por Ellenberger et al. (1989).

O tratamento T75 apresentou sempre os maiores pesos como conseqüência do Experimento I, pois ao final deste período, o ganho de peso intermediário deste tratamento proporcionou um peso inicial maior que os outros grupos. 
Outra forma interessante de observar estes dados é considerar a evolução do peso durante os dois períodos experimentais, já que ocorreram em seqüência. Estes dados estão na Figura 9. $\mathrm{O} 58^{\circ}$ dia de confinamento equivale ao final do Experimento I e a partir deste dia se inicia o segundo Experimento.

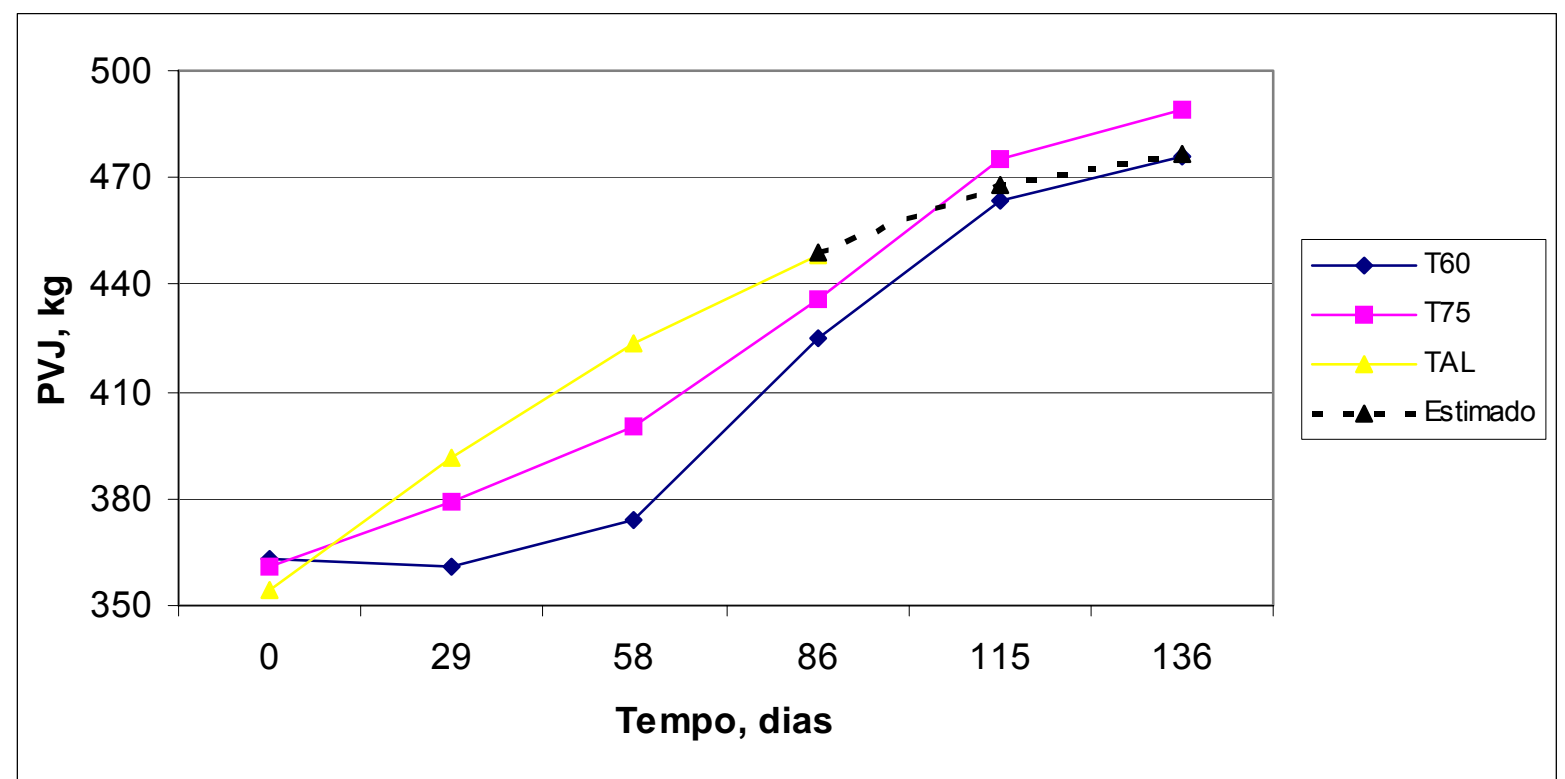

Figura 9 - Médias do peso vivo em jejum por tratamento durante os dois Experimentos

É interessante notar que no segundo período experimental do compensatório, de 86 a 115 dias, os animais da restrição superaram o peso dos animais do tratamento TAL. O compensatório foi mais evidente nos primeiros 30 dias após a realimentação, pois a partir deste período, a inclinação da curva de peso ficou mais semelhante ao tratamento TAL. A partir de 60 dias de alimentação à vontade, a elevação do peso ficou mais lenta, pois os animais já estavam em fase adiantada de deposição de gordura.

O ganho médio diário foi influenciado pelo período anterior, apresentando o ganho de peso compensatório, bem expresso pelo tratamento T60. Estes dados estão de acordo com o verificado por Sainz et al. (1995) para novilhos em fase de engorda, com dieta de alto concentrado, após período de restrição alimentar, cujos valores foram 1,22 e 1,92 kg/dia para os tratamentos sem e com restrição prévia, respectivamente. Os valores observados por Carstens et al. (1991) foram de 1,26 e $2,17 \mathrm{~kg} /$ dia para animais sem restrição ou que passaram por 189 dias de crescimento restrito. 
Os valores de ganho médio diário de 58 a 136 dias foram de 1,277 kg para T60, 1,153 kg para T75 e 1,207 kg para TAL, indicando diferenças nas taxas de ganho de peso observadas após o período de restrição alimentar. Este fato também foi observado por Tolla et al. (2003) quando trabalharam com animais zebuínos da raça Arsi.

Dados interessantes foram apresentados por Hornick et al. (1998a). Os autores consideraram que a alta eficiência de crescimento durante o compensatório pode ser mais duradoura em gado de dupla musculatura que em outras raças.

Houve interação entre os fatores tempo e tratamento $(P<0,001)$ para a ingestão de matéria seca diária. Apresentaram efeito quadrático $(P<0,001)$ para esta variável os tratamentos T60 $\left(Y=5,4655+0,1452 X-0,00135 X^{2}\right)$ e T75 $(Y=5,4012+$ $\left.0,1327 X-0,00111 X^{2}\right)$, como pode ser observado na Figura 10.

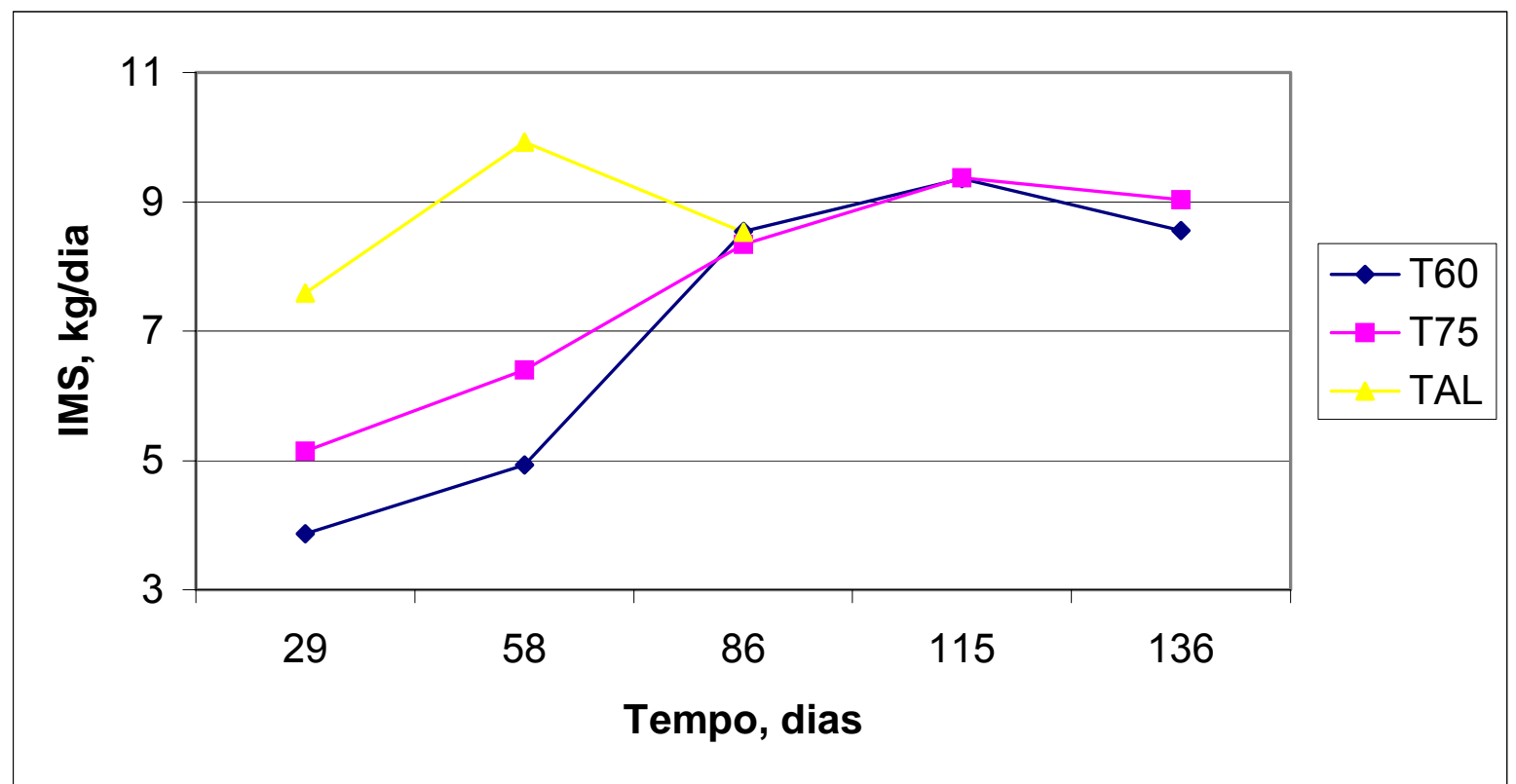

Figura 10 - Ingestão de matéria seca (IMS), média diária, para os tratamentos

O valor de IMS para o tratamento TAL no primeiro dia de realimentação, dia 59, apresentou-se muito diferente dos outros dois tratamentos por ser o valor de consumo em condições normais de alimentação. No entanto, este valor é importante porque serviu de referência para estimar a quantidade de alimento a ser fornecida aos animais que passaram por restrição no início do período de realimentação. Tolla et al. (2003) não observaram diferenças entre tratamentos para a ingestão, quando os animais estavam em ganho compensatório, semelhante ao que ocorreu com os tratamentos deste experimento. 
Já Hersom et al. (2003), observaram que para animais em realimentação, houve interação entre os fatores tempo e tratamento, sendo que nos primeiros 14 dias o consumo dos animais que passaram por restrição foi menor e após 28 dias a ingestão foi similar entre os tratamentos.

Por outro lado, Sainz et al. (1995) encontraram maiores valores de ingestão de matéria seca para animais em período posterior à restrição. E os dados de Drouillard et al. (1991) e Hornick et al. (1998a), também apresentaram maiores valores para o grupo compensando que o controle.

É interessante notar que o maior consumo de matéria seca foi apresentado pelo tratamento TAL. Este comportamento da ingestão de matéria seca, aliado ao ganho de peso diário, que esteve acima do TAL para o T60 no primeiro período e acima do TAL para os outros dois tratamentos do segundo período, caracteriza o ganho de peso compensatório.

Ryan (1990) relatou que a ingestão de alimentos para animais em realimentação não é constante e parece haver um período necessário para que os animais apresentem ingestão tão elevada quanto a dos animais com consumo livre.

$\mathrm{Na}$ eficiência alimentar houve interação entre os fatores tempo e tratamentos ( $P=0,002)$, com efeito quadrático de tempo para os tratamentos $T 60$ e $T 75$, e com efeito linear para tempo 58 e 78 e quadrático para o tempo 29. As médias dos valores estão representadas nas curvas na Figura 11 e as equações estão na Tabela 18.

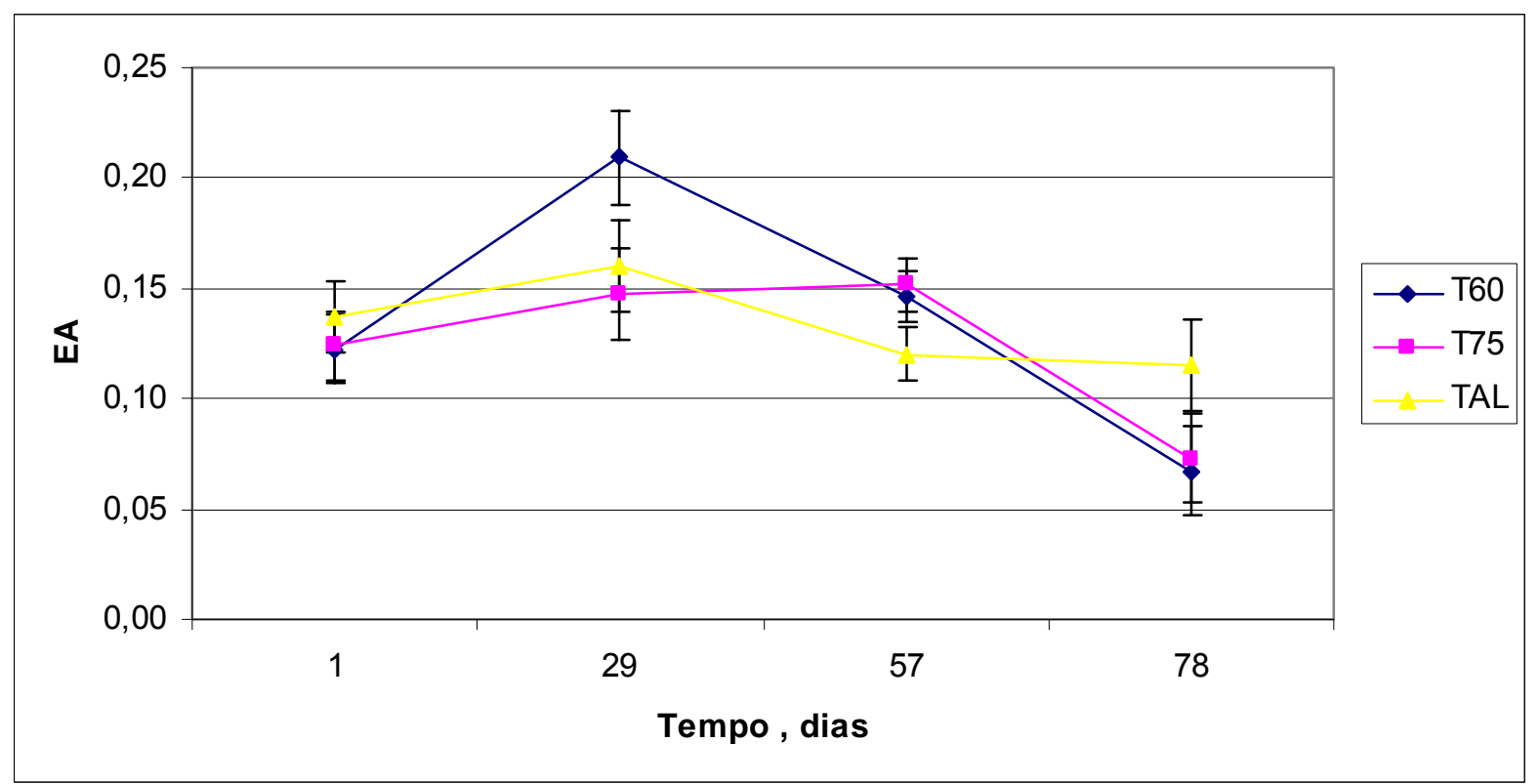

Figura 11 - Eficiência alimentar dos tratamentos nos períodos de confinamento 
Tabela 18 - Equações e valores de $\mathrm{P}$ para os efeitos de tratamento e tempo dos dados de eficiência alimentar

\begin{tabular}{lcc}
\hline Característica & Equação & $P$ \\
\hline T60 & $\mathrm{Y}=0,1221+0,004316 \mathrm{X}-0,00007 \mathrm{X}^{2}$ & $<0,001$ \\
T75 & $\mathrm{Y}=0,1128+0,003086 \mathrm{X}-0,00004 \mathrm{X}^{2}$ & $<0,001$ \\
TAL & $\mathrm{Y}=0,1246+0,001080 \mathrm{X}-0,00002 \mathrm{X}^{2}$ & $=0,040$ \\
Tempo 29 & $\mathrm{Y}=0,7116-0,01356 \mathrm{X}-0,00008 \mathrm{X}^{2}$ & 0,031 \\
Tempo 58 & $\mathrm{Y}=0,1860-0,00061 \mathrm{X}$ & 0,024 \\
Tempo 78 & $\mathrm{Y}=0,002045+0,001082 \mathrm{X}$ & 0,018 \\
\hline
\end{tabular}

A eficiência alimentar diminuiu com o passar do tempo de confinamento, sendo que o tratamento T60, com animais em ganho de peso compensatório, foi mais eficiente que o grupo TAL até os 60 dias. Ellenberger et al. (1985) encontraram melhor eficiência durante os primeiros 36 dias de realimentação. Sainz et al. (1995) observaram melhor eficiência para animais que passaram por restrição. A diminuição na eficiência alimentar com o passar do tempo de confinamento também foi observada por Carstens et al. (1991), diminuindo de 0,260 para 0,170.

Segundo Ryan (1990) quando um animal é realimentado tanto a síntese como a degradação de proteína aumenta. Se a taxa de síntese aumenta mais rapidamente do que a taxa de degradação, então haverá redução no custo energético da deposição de proteína e um aumento na eficiência. Se a proporção de energia depositada como proteína aumenta, o ganho em peso será maior por unidade de energia depositada por causa de água retida quando a proteína é depositada.

\subsubsection{Composição do ganho durante a realimentação}

Para determinar o peso do corpo vazio dos animais no início e final dos Experimentos I e II, foi realizada, ao final do Experimento II, no abate, a pesagem das vísceras sem o seu conteúdo. Com os dados de peso vivo em jejum e peso do corpo vazio foi possível estabelecer uma equação para estes animais, que foi usada para determinar o peso do corpo vazio quando das aplicações de deutério.

A equação encontrada foi $Y=15,75+0,9852\left(R^{2}=0,96\right)$, que comparada com outras equações da literatura se mostrou mais indicada para este trabalho. 
Os pesos dos animais no início e final do período experimental estão apresentados na Tabela 19.

Tabela 19 - Período de confinamento, peso em jejum inicial e final, peso do corpo vazio inicial e final e espessura de gordura subcutânea (EGS)

\begin{tabular}{lccc}
\hline \multirow{2}{*}{ Característica } & \multicolumn{3}{c}{ Tratamentos } \\
\cline { 2 - 4 } & T60 & T75 & TAL \\
\hline Período de confinamento, (dias) & 77 & 77 & 77 \\
Peso vivo jejum inicial, $(\mathrm{kg})$ & 378,04 & 400,42 & 356,15 \\
Peso vivo jejum final, $(\mathrm{kg})$ & 476,33 & 489,17 & 439,77 \\
Peso corpo vazio inicial, $(\mathrm{kg})$ & 356,70 & 378,74 & 335,13 \\
Peso corpo vazio final, $(\mathrm{kg})$ & 453,53 & 466,18 & 417,52 \\
EGS, $(\mathrm{mm})$ & 5 & 6 & 5 \\
\hline
\end{tabular}

O peso vivo em jejum inicial para os tratamentos T60 e T75 foi o peso aos 58 dias de confinamento, quando terminou o Experimento I e para o TAL foi o peso inicial do Experimento I. O peso vivo em jejum final dos tratamentos T60 e T75 foram determinados ao final do Experimento II, após terem passado por 77 dias de realimentação, e do tratamento TAL foi determinado aos 77 dias de confinamento quando foram abatidos.

Os dados referentes à composição corporal dos animais no início e final do período experimental determinados por deutério estão na Tabela 20.

Tabela 20 - Composição percentual do corpo vazio inicial e final, determinadas pelo espaço de deutério

\begin{tabular}{lccc}
\hline \multirow{2}{*}{ Característica } & \multicolumn{3}{c}{ Composição do corpo vazio inicial } \\
\cline { 2 - 4 } \% Água & $\mathrm{T} 60$ & $\mathrm{~T} 75$ & $\mathrm{TAL}$ \\
\% Extrato etéreo & 59,26 & 58,89 & 61,09 \\
\% Proteína & 18,31 & 18,79 & 15,98 \\
\% Cinzas & 17,83 & 17,72 & 18,38 \\
Energia, (Mcal/kg) & 4,43 & 4,40 & 4,56 \\
\hline \multirow{2}{*}{ Característica } & 2,73 & 2,77 & 2,54 \\
\hline \% Água & \multicolumn{2}{c}{ Composição do corpo vazio final } \\
\% Extrato etéreo & $\mathrm{T} 60$ & $\mathrm{~T} 75$ & $\mathrm{TAL}$ \\
\% Proteína & 54,23 & 53,87 & 57,97 \\
\% Cinzas & 24,73 & 25,19 & 19,96 \\
Energia, (Mcal/kg) & 16,32 & 16,21 & 17,44 \\
\hline
\end{tabular}


A composição do corpo vazio de novilhos Nelore encontrada por Alleoni et al. (1997) foi $57,5 \%$ de água, $21,2 \%$ de extrato etéreo, $17,1 \%$ de proteína e $4,2 \%$ de cinzas. Goulart (2006) observou a seguinte composição do corpo vazio ao abate: $55,5 \%$ de água, $22,3 \%$ de extrato etéreo, $17,8 \%$ de proteína bruta, $4,4 \%$ de cinzas e $3,10 \mathrm{Mcal} / \mathrm{kg}$ de energia para novilhos Nelore.

Os dados encontrados por Putrino (2006) indicaram que, para novilhos Nelore com $6,0,7,5,7,7$ e 9,6 mm de gordura subcutânea a quantidade de extrato etéreo variou de 20,9 a $22 \%$.

Os dados obtidos por $\mathrm{D}_{2} \mathrm{O}$ foram adequados à condição dos animais que passaram por ganho de peso compensatório e que apresentavam 5 a $6 \mathrm{~mm}$ de espessura de gordura na carcaça, visto que ao abate é esperado teor de extrato etéreo maior que $20 \%$ como relatado pelos trabalhos de Alleoni et al. (1997), Putrino (2006) e Goulart (2006).

$\mathrm{Na}$ Tabela 21 encontram-se as quantidades de água, gordura, proteína e cinzas no corpo vazio dos animais no início e final do período experimental.

Tabela 21 - Composição química do corpo vazio inicial e final

\begin{tabular}{lccc}
\hline \multirow{2}{*}{ Característica } & \multicolumn{3}{c}{ Tratamentos } \\
\cline { 2 - 4 } & \multicolumn{3}{c}{ Composição inicial } \\
\cline { 2 - 4 } Água, kg & 211,21 & 222,73 & TAL \\
Extrato etéreo, kg & 65,55 & 71,55 & 204,09 \\
Proteína, kg & 63,55 & 67,02 & 54,01 \\
Cinzas, kg & 15,78 & 16,64 & 1,41 \\
& \multicolumn{3}{c}{ Composição final } \\
\hline Água, kg & 245,54 & 250,36 \\
Extrato etéreo, kg & 112,70 & 118,43 & 233,25 \\
Proteína, kg & 73,88 & 75,33 & 81,57 \\
Cinzas, kg & 18,34 & 18,70 & 70,19 \\
\hline
\end{tabular}

As taxas de deposição dos componentes corporais e a composição do ganho de peso vazio dos animais são apresentadas na Tabela 22. 
Tabela 22 - Taxa de deposição dos componentes químicos corporais no corpo vazio e composição do ganho de peso vazio

\begin{tabular}{lccc}
\hline \multirow{2}{*}{ Característica } & \multicolumn{3}{c}{ Tratamentos } \\
\cline { 2 - 4 } & \multicolumn{3}{c}{ Taxa de deposição } \\
\cline { 2 - 4 } & 1,277 & 1,153 & 1,207 \\
Ganho de peso jejum, kg/dia & 1,258 & 1,136 & 1,189 \\
Ganho de peso vazio, kg/dia & 0,446 & 0,359 & 0,503 \\
\hline Água, kg/dia & 0,612 & 0,609 & 0,475 \\
Extrato etéreo, kg/dia & 0,134 & 0,108 & 0,151 \\
Proteína, kg/dia & 0,033 & 0,027 & 0,038 \\
Cinzas, kg/dia & 1,226 & 1,102 & 1,167 \\
Soma & 6,50 & 6,32 & 5,31 \\
Energia, Mcal/dia & Composição do ganho de peso vazio \\
\hline & 35,95 & 32,68 & 42,57 \\
\hline$\%$ Água & 50,55 & 55,05 & 41,44 \\
\% Extrato etéreo & 10,82 & 9,83 & 12,81 \\
\% Proteína & 2,68 & 2,44 & 3,18 \\
\% Cinzas & 5,21 & 5,54 & 4,52 \\
Energia (Mcal/kg GPCVz) & \multicolumn{3}{c}{. } \\
\hline
\end{tabular}

A composição do ganho de peso vazio dos tratamentos em compensatório diferencia-se especialmente no conteúdo de extrato etéreo quando comparada à composição dos animais que não passaram por restrição. Este fato foi descrito por Wright e Russel (1991) quando observaram que ao final do período de realimentação, quando os animais atingiram $450 \mathrm{~kg}$, a deposição de gordura aumentou e a de proteína e água diminuiu.

Lanna et al. (1998), usando a técnica de diluição de deutério, observaram as proporções dos constituintes químicos no ganho diário de peso de corpo vazio para novilhas, que variaram entre 38 e $46 \%$ para água, 35 a 46\% para extrato etéreo, 11 a $14 \%$ para proteína e 4 a $5 \%$ para cinzas. Considerando que fêmeas apresentam maior deposição de gordura no ganho que os machos castrados, quando em confinamento de terminação, pode-se dizer que os dados encontrados para os novilhos deste experimento ficaram dentro do esperado.

Os dados deste trabalho foram semelhantes aos encontrados por Galati et al. (2007), que determinaram a composição dos nutrientes no corpo vazio de novilhos Nelore, encontrando $53,7 \%$ de água, $25,0 \%$ de extrato etéreo, $17,9 \%$ de proteína e $3,4 \%$ de cinzas. 


\subsubsection{Digestibilidade da dieta}

A digestibilidade da dieta não diferiu entre os tratamentos $(P=0,236)$ e está representada na Figura 12.

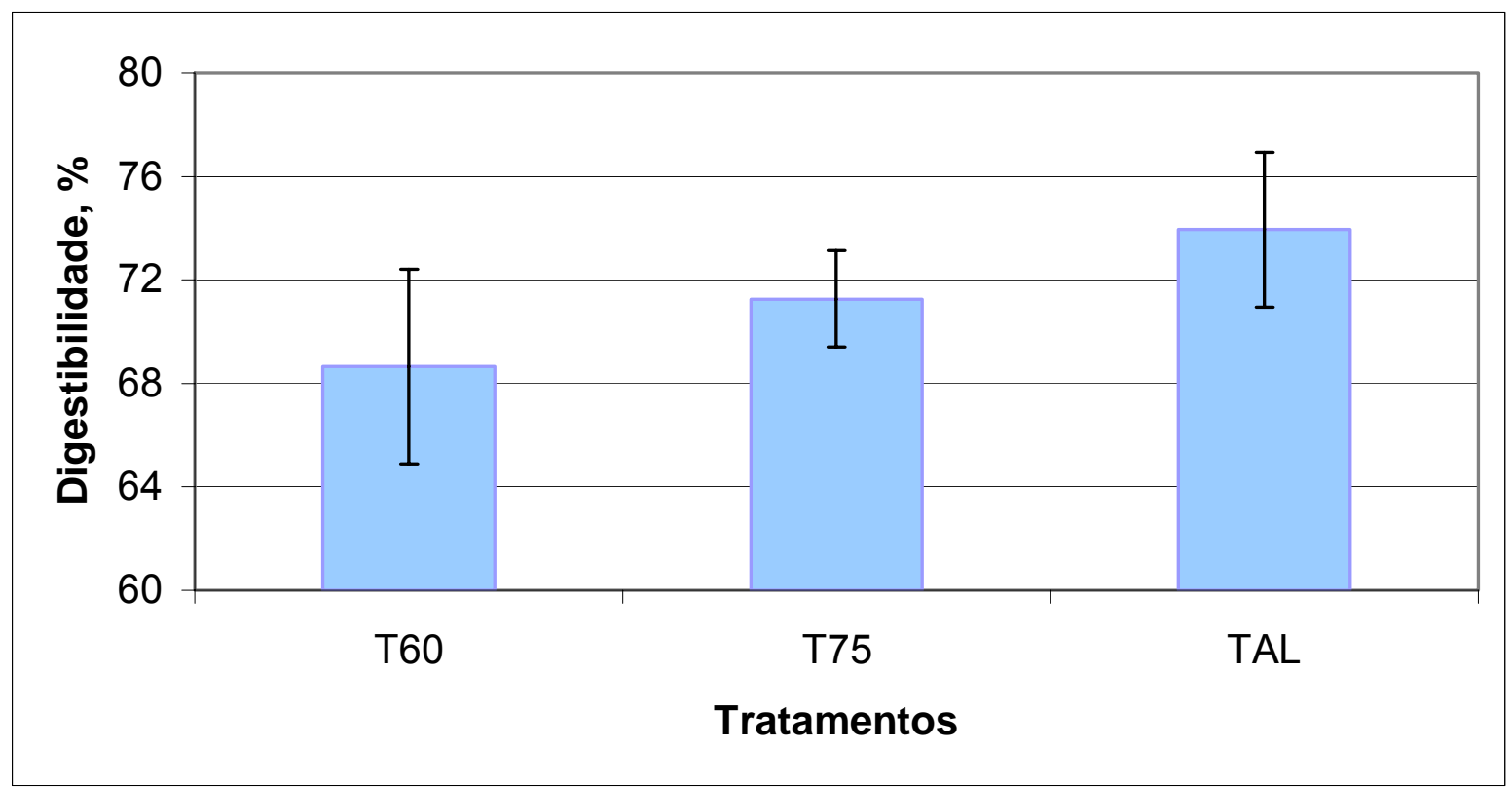

Figura 12 - Digestibilidade da dieta para os tratamentos no Experimento II

No entanto, os valores foram diferentes do primeiro Experimento. Este fato era esperado, pois a maior ingestão de alimentos aumenta a taxa de passagem, o que diminui a exposição do alimento aos agentes digestivos do trato gastrintestinal. A diminuição na digestibilidade dos nutrientes, determinada em novilhos que estavam em compensatório, também foi verificada por Hayden et al. (1993). Os valores encontrados foram de $71 \%$ para o grupo que estava em realimentação e $76 \%$ para o grupo alimentado à vontade.

Também Hersom et al. (2003) observaram que, na fase inicial de realimentação, a digestibilidade do grupo que passou por período de ganho de peso moderado foi menor que a digestibilidade do grupo com ganho elevado por todo o período. Os autores verificaram que nos primeiros 28 dias de realimentação o ganho de peso diário dos animais realimentados foi maior que dos animais de ganho constante, embora o peso vivo final tenha sido menor.

A comparação dos valores entre tratamentos pode ser observada na Figura 13 onde fica evidente a alteração na digestibilidade das dietas, observada nos 
mesmos animais, quando estão alimentados restritamente ou à vontade com a mesma dieta.

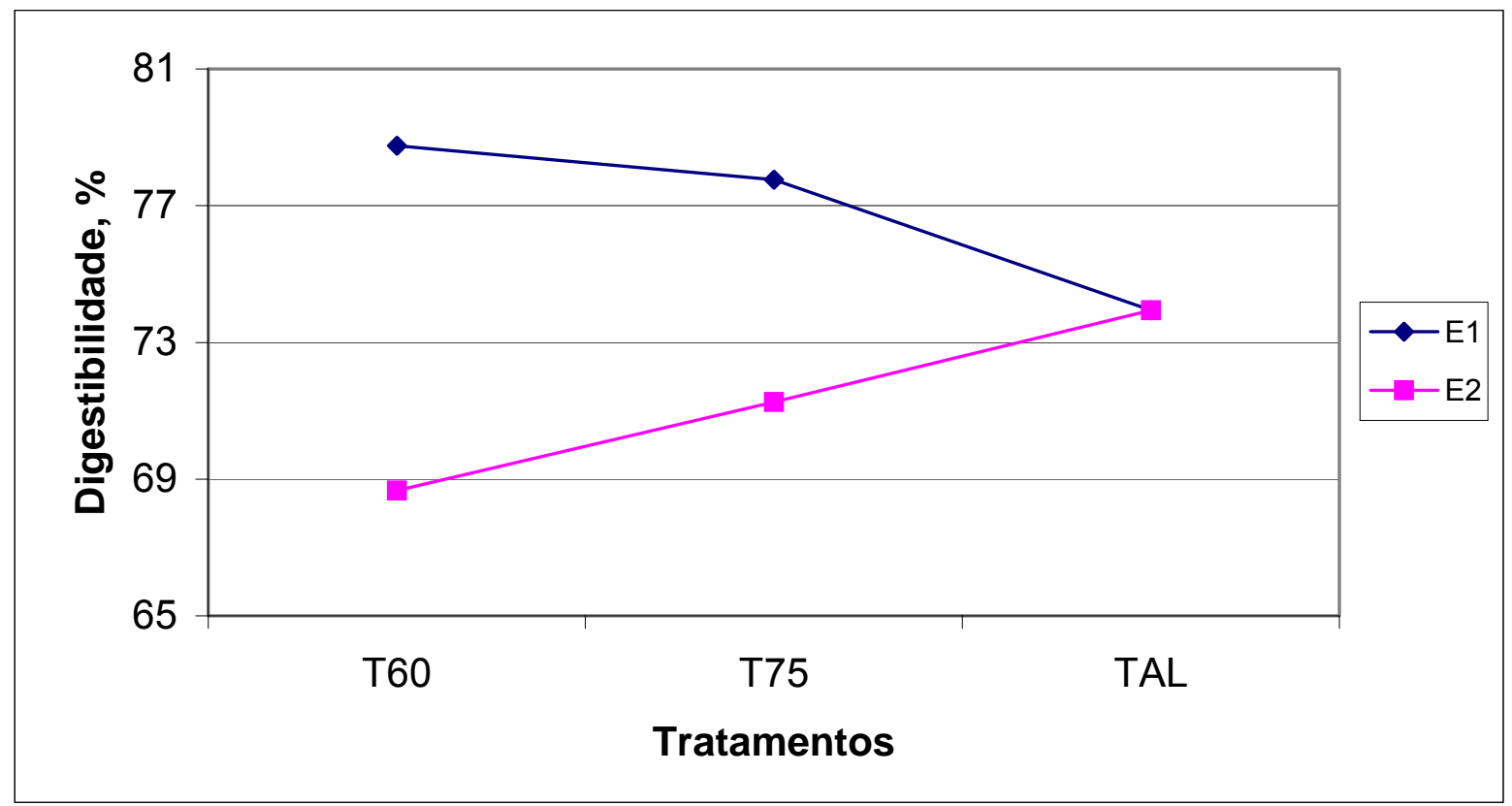

Figura 13 - Digestibilidade da dieta para os tratamentos no Experimento I e II (E1 e E2)

\subsubsection{Perfil hormonal e parâmetros sanguíneos}

Os valores de perfil hormonal e parâmetros sangüíneos na realimentação foram avaliados apenas para os tratamentos $\mathrm{T} 60$ e T75, que passaram por esta fase. Portanto, os valores referentes a estes tratamentos neste período, equivalem aos dias 71, 84, 112 e 132.

5.1.5.1 Concentração plasmática de IGF-I, T3 e T4

Para a concentração de IGF-I houve efeito linear de tempo $(P=0,004)$, com a equação $Y=563,30 \pm 22,41-2,1546 \pm 0,4456 X$. Na Figura 14 encontram-se os valores de concentração de IGF-I durante o Experimento I, que aconteceu até o dia 55, e o Experimento II, que compreende os quatro seguintes pontos de colheita. 


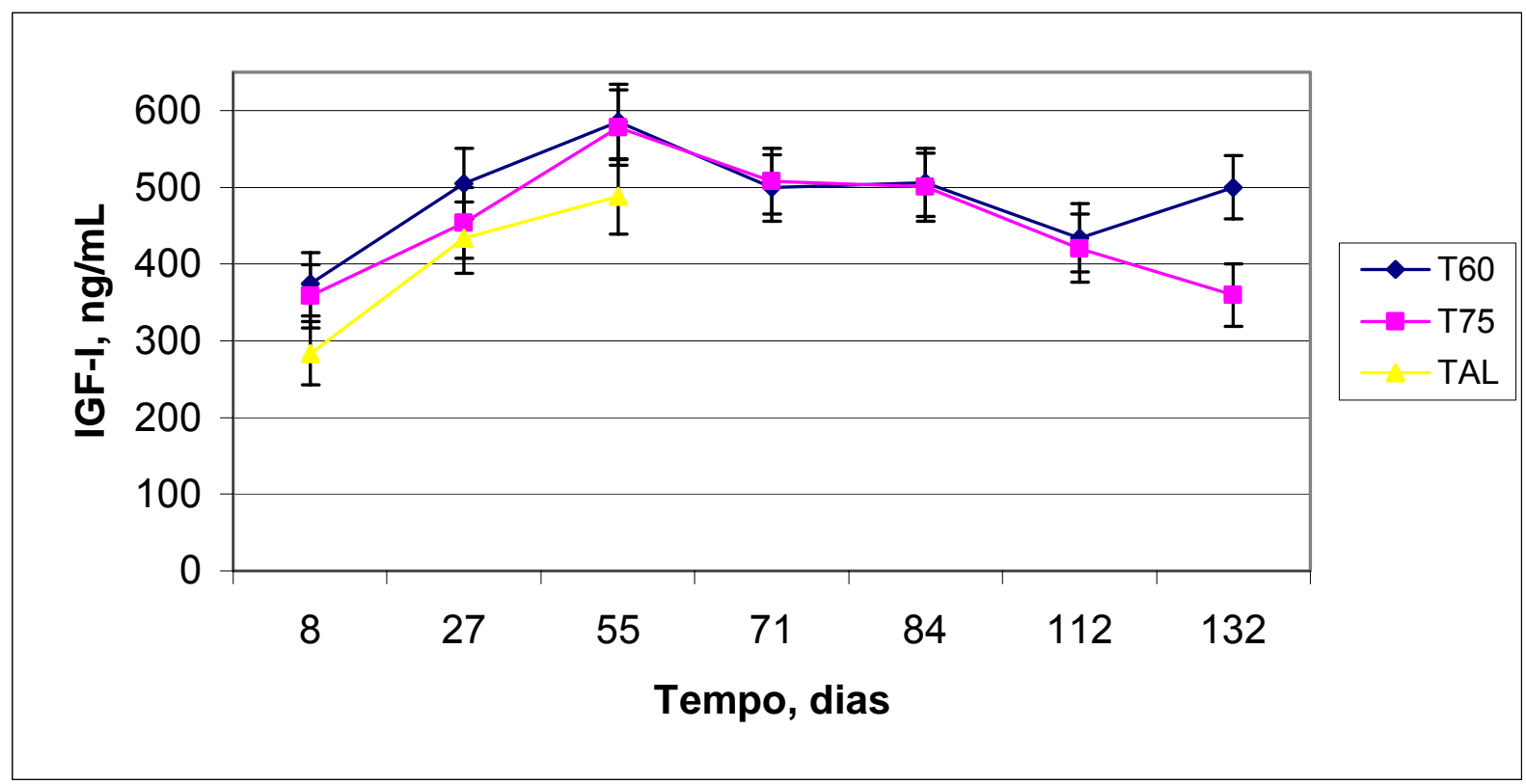

Figura 14 - Concentração plasmática de IGF-I dos tratamentos, considerando os dois Experimentos

É possível que a queda nas concentrações de IGF-I a partir do dia 55 seja efeito do ganho de peso compensatório, bem como da mudança na composição do ganho de peso.

Os valores encontrados na fase de realimentação estão distantes do verificado por Cabaraux et al. (2005) para vacas Belgian Blue em engorda, que foi de $104,6 \mathrm{ng} / \mathrm{ml}$. Os autores consideraram que estes níveis mais baixos de IGF-I circulante, quando comparados aos valores de novilhas Angus e Hereford, podem ser resultado de migração do hormônio para os tecidos periféricos por causa do maior desenvolvimento muscular em raça de dupla musculatura.

Os valores encontrados por Ellenberger et al. (1989) para novilhos com 430 $\mathrm{kg}$ de peso vivo não diferiram entre si e foram maiores, $214,9 \mathrm{ng} / \mathrm{mL}$ para animais controle e $227,3 \mathrm{ng} / \mathrm{mL}$ para o grupo compensando, que os valores observados por Cabaraux et al. (2005), mas ainda inferiores aos observados no presente trabalho. No entanto, Ellenberger et al. (1989) observaram queda nas concentrações ao longo do tempo, sendo que aos $510 \mathrm{~kg}$ de peso vivo os valores dos animais que sofreram restrição foram superiores aos do grupo controle.

No estudo de Hayden et al. (1993), houve aumento linear nas concentrações de IGF-I, tendo o grupo restrito valores inferiores ao grupo sem restrição. Aos 60 dias de realimentação os valores estavam próximos a $350 \mathrm{ng} / \mathrm{mL}$. 
Um efeito quadrático no tempo para as concentrações de IGF-I de tourinhos Belgian Blue foi observado por Hornick et al. (1998b). O efeito foi verificado em todos os tratamentos, três períodos de restrição e um controle, e durante os períodos de restrição ou realimentação.

Os valores de concentração de T3 não foram diferentes entre os tratamentos $(P=0,570)$ e não houve interação entre tempo e tratamento $(P=0,979)$. Os valores estão representados na Figura 15.

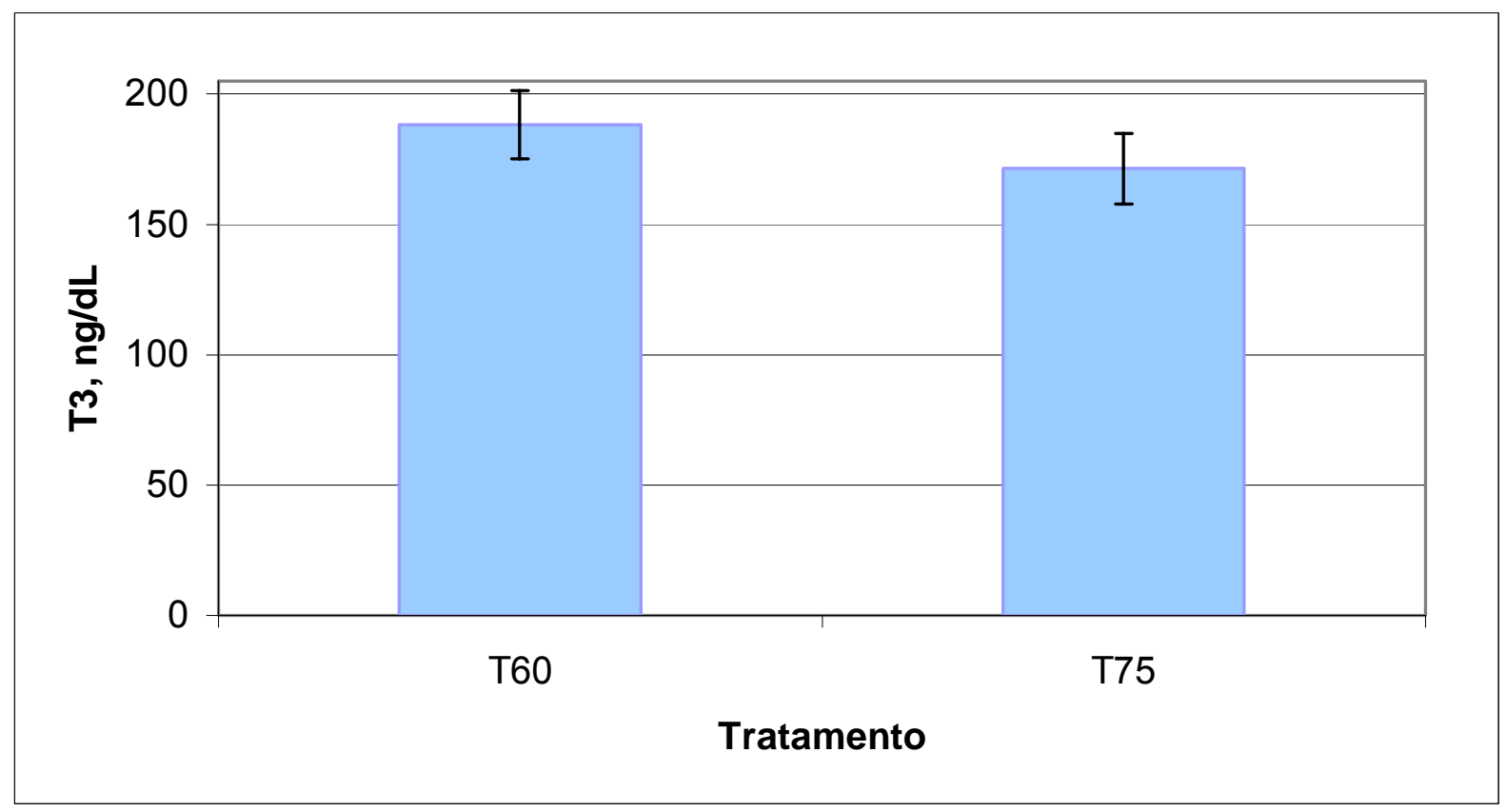

Figura 15 - Concentrações médias dos tratamentos para T3

As concentrações de T3 para novilhos em realimentação estudados por Blum et al. (1985) aumentaram, contrariamente aos dados observados neste trabalho, apesar de estarem dentro da mesma faixa de concentração. Neste mesmo sentido, os dados de Ellenberger et al. (1989) para novilhos em compensatório também estiveram próximos dos $200 \mathrm{ng} / \mathrm{dL}$, mas sem diferenças entre os tratamentos.

Em estudo do ganho compensatório de novilhos, Hayden et al. (1993) observaram interação entre tempo e tratamento, sendo que as concentrações de T3 aos 30 e 60 dias foram semelhantes para os animais compensando ou não, com valores mais elevados na última dosagem.

Na Figura 16 encontram-se os valores de concentração de T3 durante o Experimento I, que aconteceu até o dia 55, e o Experimento II, que compreende os quatro seguintes pontos de colheita. 


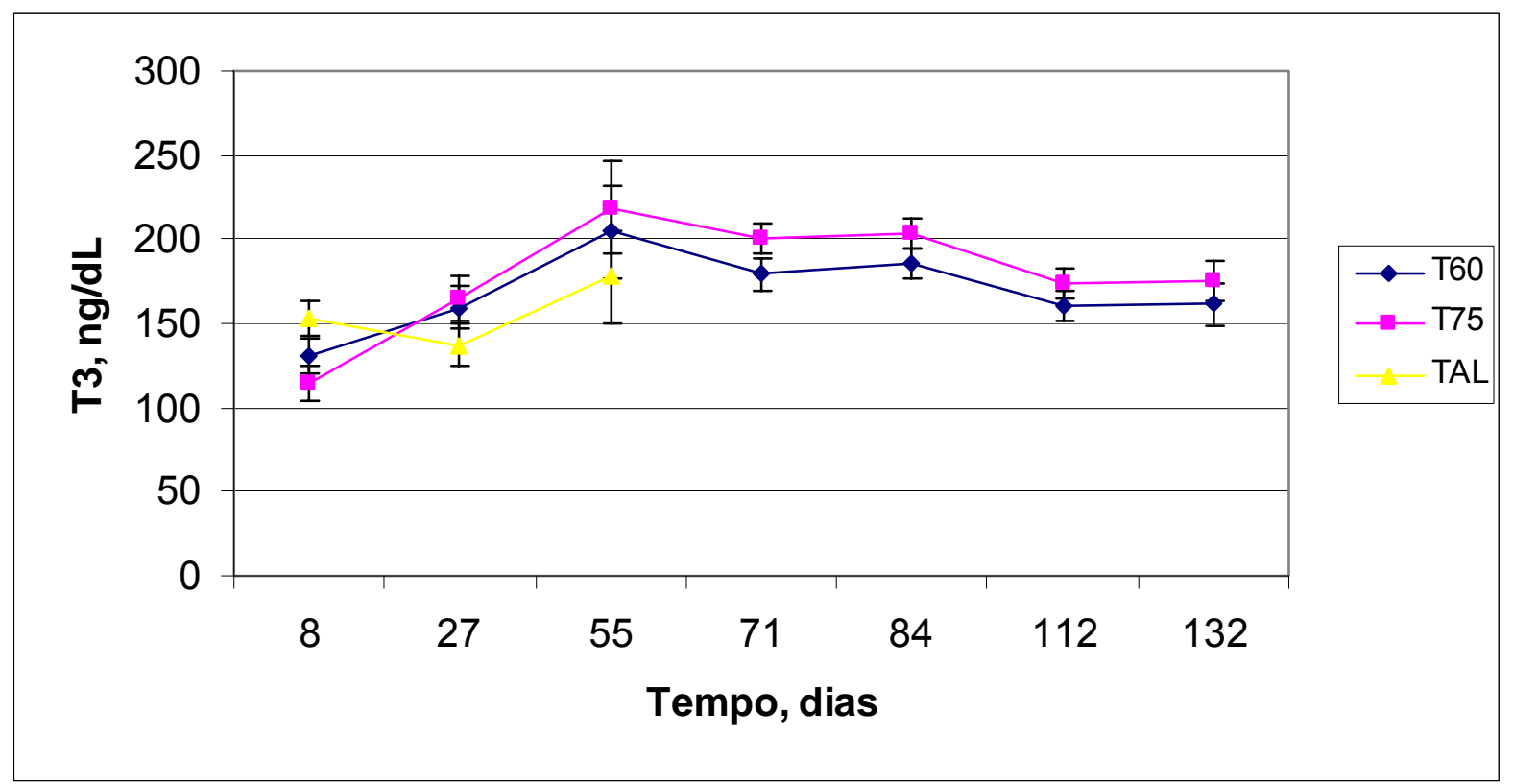

Figura 16 - Concentração de T3 dos tratamentos, considerando os dois Experimentos

As concentrações de T3 e T4 para vacas de descarte em confinamento observadas por Cabaraux et al. (2005) foram menores que os valores observados por outros autores para tourinhos jovens, o que levou os autores a sugerirem que o metabolismo geral em fêmeas é menor, provavelmente devido ao sexo e a idade dos animais.

Os valores de T3 observados por Hornick et al. (1998b) para novilhos de dupla musculatura, com ganho de peso de 0,5 kg/dia por período de 114 dias, tiveram um efeito quadrático. Em contraste, segundo os autores, a evolução de T4 foi estável no grupo controle e aumentou linearmente durante a fase de realimentação para os grupos que passaram por restrição. Estes resultados sugerem que T3 é um melhor indicador das trocas nas taxas de crescimento e composição do crescimento. A sensibilidade de T3 aos fatores ambientais também é sugerida pela resposta dos animais do grupo com período de 243 dias de restrição, que apresentaram o maior aumento na concentração de T3 na terminação, que foi durante o inverno (Hornick et al., 1998b).

Os efeitos climáticos sobre as concentrações plasmáticas de T3 e T4 também foram observados por Ribeiro et al. (2006) em bezerros Nelore e cruzados.

Como citado anteriormente, segundo Reece (1996), tem sido cogitado que a elevação do calor é secundária ao incremento na síntese protéica estimulados pelos 
hormônios da tireóide. Portanto, podemos considerar que os valores de T3 nesta fase não sofreram interferência climática que teve o mesmo efeito nos animais, tendo estes passado por restrição ou não.

A concentração plasmática de T4 não apresentou interação entre os fatores tempo e tratamentos $(P=0,734)$ e não houve diferença entre os tratamentos $(P=0,995)$ e no tempo ( $P=0,353)$. A Figura 17 apresenta os dados de concentração de T4 para os tratamentos durante os dois experimentos.

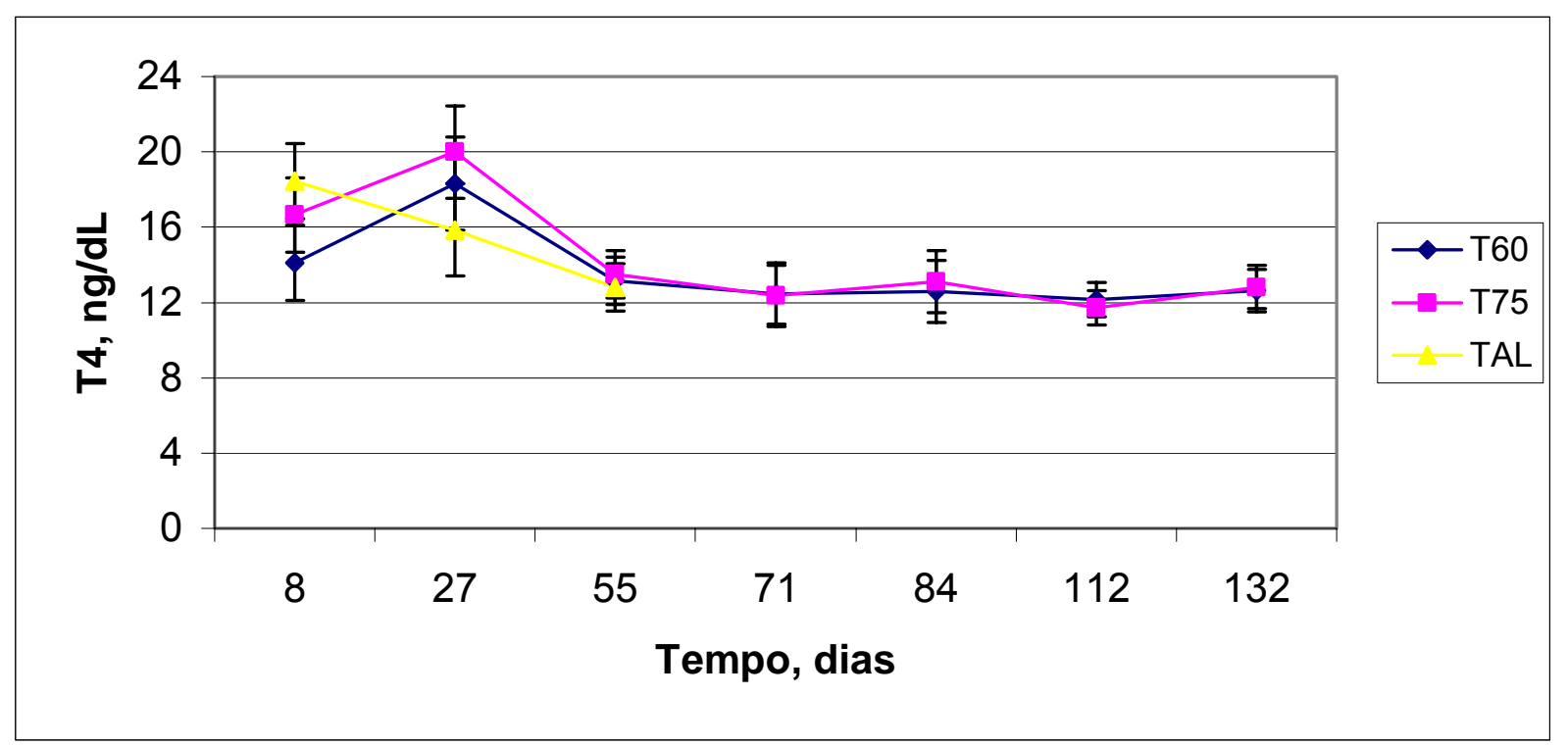

Figura 17 - Concentração de T4 dos tratamentos, considerando os dois Experimentos

Os dados obtidos por Blum et al. (1985) para T4 foram contrários ao observado neste experimento.

No trabalho de Ellenberger et al. (1989), não foram observadas diferenças entre os tratamentos para os valores de T4 nos novilhos até $430 \mathrm{~kg}$. Já aos $510 \mathrm{~kg}$ de peso vivo o tratamento restrito, na fase de compensatório, resultou em valores menores deste hormônio que nos animais do grupo sem restrição. Estes dados são semelhantes aos que observamos.

Já os valores observados por Hayden et al. (1993) foram diferentes entre os tratamentos, restritos ou não, e ambos apresentaram comportamento linear com maiores valores para os 60 dias de realimentação.

Durante o período de realimentação, Hornick et al. (1998b), encontraram aumento linear nas concentrações de T4 de novilhos Belgian Blue em terminação, 
após serem mantidos por diferentes períodos de ganho de peso moderado. Entretanto, até os 100 dias de ganho de peso elevado não houve diferença entre os grupos restritos, que permaneceram abaixo dos valores observados para o grupo controle.

\subsubsection{Concentração de glicose, proteína total e nitrogênio}

Não houve interação $(P=0,388)$ nos dados de glicose entre os fatores tratamentos e tempo, e não houve diferença entre os tratamentos $(P=0,991)$. Na Figura 18 estão representados os valores médios de glicose para os tratamentos ao longo dos Experimentos I e II.

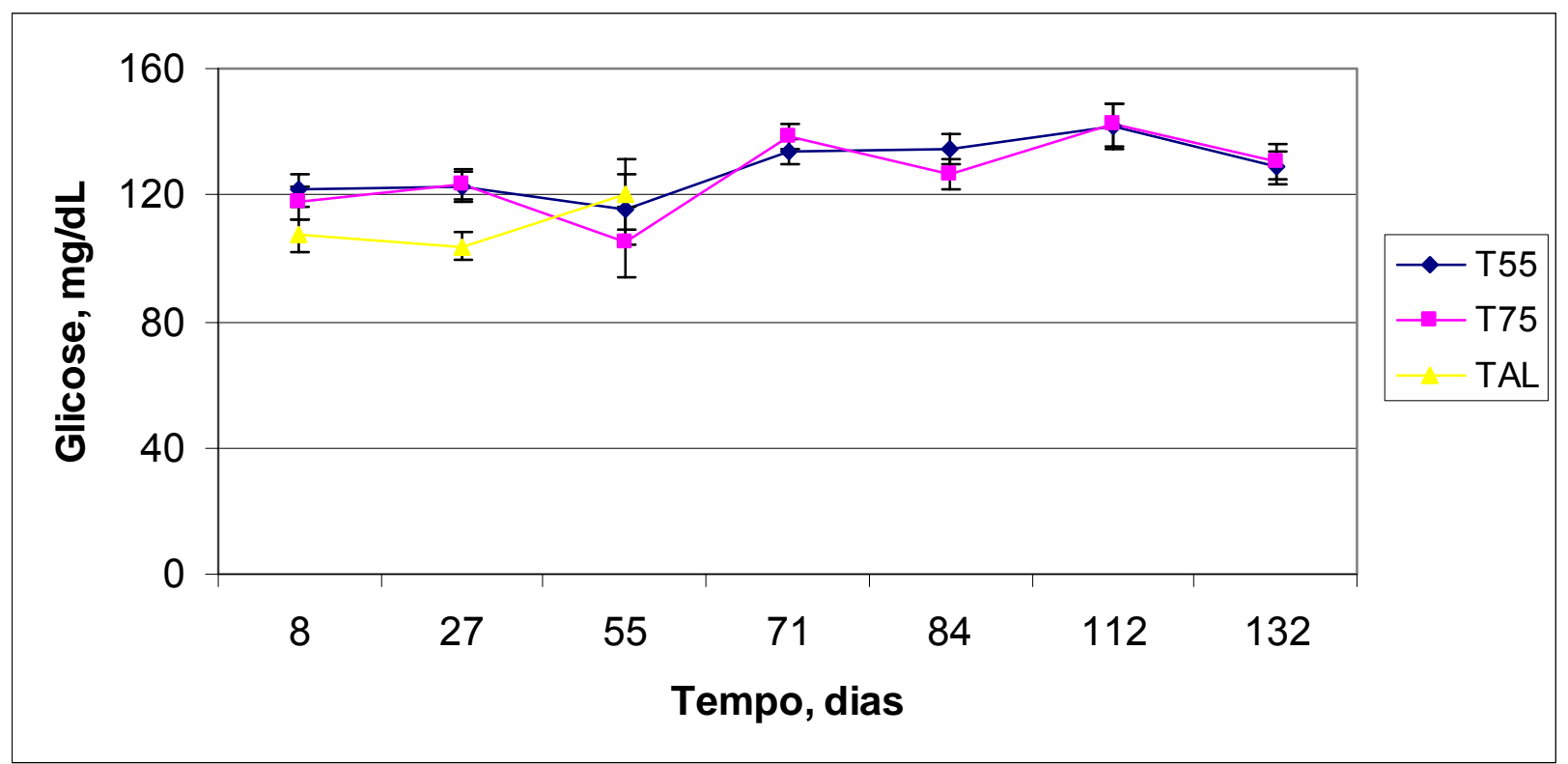

Figura 18 - Concentração de glicose ao longo dos dois experimentos

Em estudo do ganho compensatório em novilhos Chianina, Hayden et al. (1993) observaram uma resposta linear do grupo restrito-realimentado alcançando os valores do grupo não restrito ( $85 \mathrm{mg} / \mathrm{dL})$, aos 30 dias de realimentação.

As concentrações de glicose plasmática que foram observadas para os animais Nelore do presente estudo são praticamente o dobro dos valores observados por Blum et al. (1985), no entanto, os autores observaram a mesma elevação nas concentrações de glicose para novilhos em realimentação. Por outro lado, Ellenberger et al. (1989) encontraram efeito quadrático inverso para esta 
variável, com pico máximo de concentração de $106 \mathrm{mg} / \mathrm{dL}$ para novilhos cruzados de raças taurinas aos $430 \mathrm{~kg}$ de peso. Um fato interessante que estes autores ressaltam é que a glicose sanguínea não aumentou tão rapidamente quanto a ingestão de alimentos durante a realimentação, e isto poderia refletir a maior demanda por hipertrofia, no fígado e intestino, nesta fase.

A avaliação da concentração de glicose em tourinhos Belgian Blue no ganho de peso compensatório foi estudada por Hornick et al. (1998b), que observaram aumento nos valores deste parâmetro. Os autores comentam que o aumento na concentração de glicose na realimentação provavelmente foi resultado de maior produção ruminal do precursor da glicose, o ácido propiônico, associado à maior ingestão de concentrado.

No trabalho de Oliveira Jr. et al. (2004), novilhos cruzados Nelore alimentados com $80 \%$ de concentrado não apresentaram diferenças entre os valores de glicose, que variou de 62,2 a 69,8 mg/dL. Mendes et al. (2005) também não observaram diferenças nas concentrações plasmáticas de glicose (80 mg/dL) para novilhos cruzados Simental -Nelore alimentados com $61 \%$ de concentrado.

Valores mais altos, $136,25 \mathrm{mg} / \mathrm{dL}$, foram relatados por Ribeiro et al. (2006) para bezerros de aproximadamente um dia de vida.

A idade e a atividade do animal são fatores importantes que podem alterar os valores sangüíneos (SWENSON, 1996). Os valores relatados por Swenson (1996) para a concentração de glicose em vaca e bezerro são respectivamente 40 a 80 $\mathrm{mg} / \mathrm{dL}$ e 80 a $120 \mathrm{mg} / \mathrm{dL}$. Tendo como referência estes valores, as variações da glicose observadas neste trabalho estão dentro das concentrações normais.

Para a concentração de proteína total $(P T)$ não houve interação $(P<0,356)$ entre os fatores tempo e tratamento e não houve efeito de tratamento $(0,878)$. Os valores médios da concentração de PT para os tratamentos nos dois experimentos estão representados na Figura 19. 


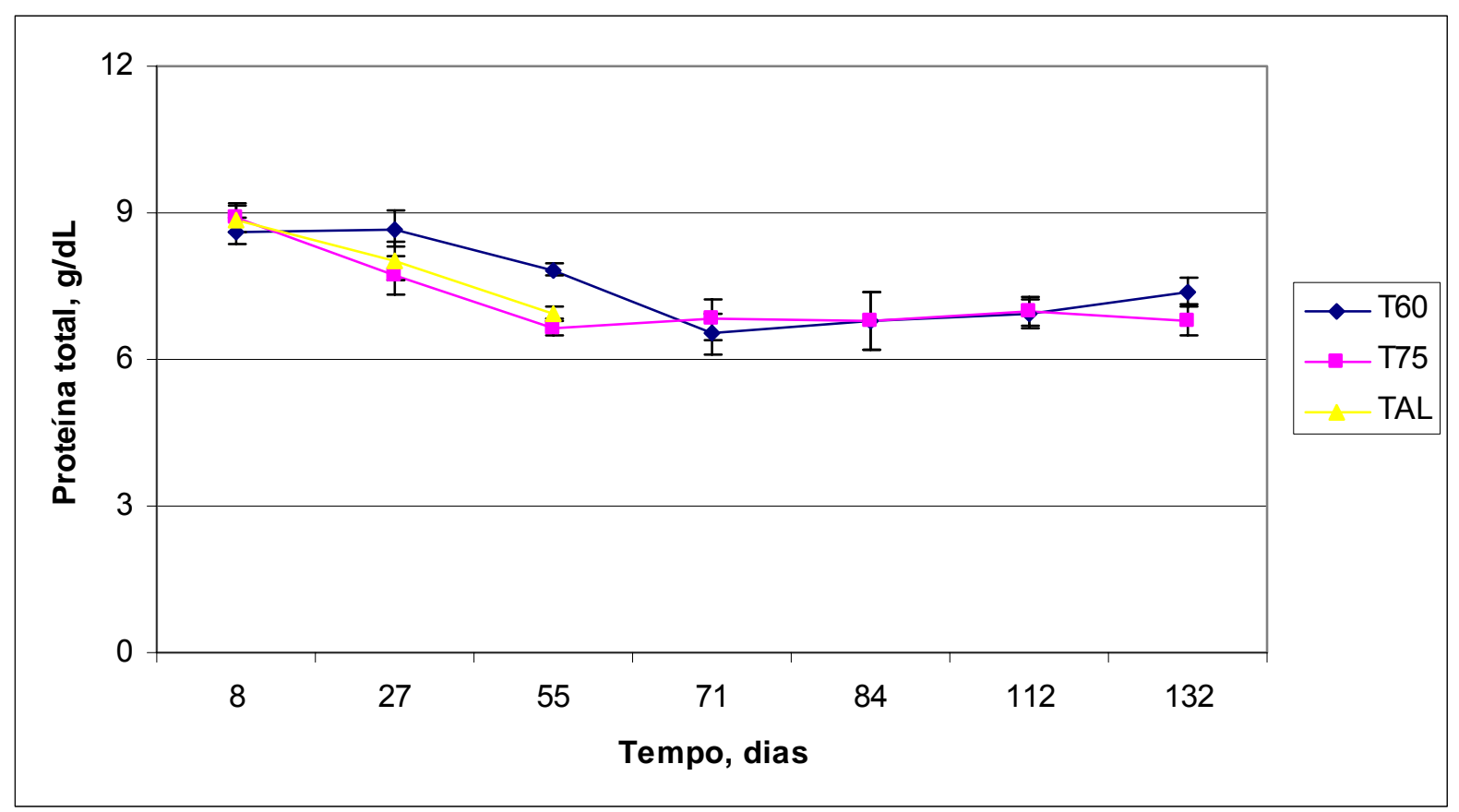

Figura 19 - Valores médios da concentração de proteína total nos Experimentos I e II

As concentrações médias de proteína total foram inferiores aos valores observados por Mendes et al. (2005), para novilhos cruzados em confinamento, que foi de $7,92 \mathrm{~g} / \mathrm{dL}$.

Segundo Swenson (1996) os valores de proteína total para vacas variam entre 7,0 a 8,5 g/dL e segundo Reece (1996) estão entre 5 a $8 \mathrm{~g} / \mathrm{dL}$.

Quando a concentração de aminoácidos nas células teciduais diminui abaixo daquela do plasma, os aminoácidos entram nas células e são usados para a síntese de proteínas tissulares e essenciais ao plasma (SWENSON, 1996). Portanto, os valores observados que estão abaixo de $7,0 \mathrm{~g} / \mathrm{dL}$, especialmente nos tratamentos T60 e T75, poderiam indicar maior síntese protéica destes tratamentos durante a fase de ganho compensatório. O valor numericamente superior observado no tempo 132 para o tratamento $\mathrm{T} 60$, que apresentou ganho compensatório, poderia estar relacionado com menor síntese protéica em favorecimento da deposição de gordura na fase final de confinamento.

Para a concentração de nitrogênio uréico no plasma (NUP) houve interação $(P=0,005)$ entre os fatores tratamentos e tempo. Os valores estão apresentados na Tabela 23. 
Tabela 23 - Valores médios de NUP para tempo e tratamento

\begin{tabular}{|c|c|c|c|c|c|}
\hline \multirow{2}{*}{ Tratamento } & \multicolumn{4}{|c|}{ Tempo } & \multirow{2}{*}{$P$} \\
\hline & 71 & 84 & 112 & 132 & \\
\hline T60 & 21,95 & 25,24 & 16,00 & 13,91 & $<0,001$ \\
\hline T75 & 23,27 & 19,61 & 16,46 & 13,73 & $<0,001$ \\
\hline SE & 1,48 & 1,29 & 1,76 & 1,68 & \\
\hline $\mathrm{P}$ & 0,043 & $<0,001$ & 0,002 & 0,010 & \\
\hline \multicolumn{2}{|c|}{ Efeito de tempo } & \multicolumn{3}{|c|}{ Equação } & $\mathrm{P}$ \\
\hline T60 & & \multicolumn{3}{|c|}{$Y=26,52 \pm 1,520-0,170 \pm 0,028 X$} & $<0,001$ \\
\hline T75 & & \multicolumn{3}{|c|}{$Y=24,57 \pm 1,520-0,147 \pm 0,028 X$} & $<0,001$ \\
\hline
\end{tabular}

Para o tratamento T60 houve um distanciamento no tempo 84, como pode ser observado na Figura 33, indicando que estes animais estavam com maior taxa metabólica, já que neste período apresentaram maior EA para a mesma ingestão de matéria seca. A queda nos valores de NUP no período 55 pode ser reflexo da diminuição no consumo e no ganho de peso, para os tratamentos T60 e T75.

Na Figura 20 estão representadas as médias dos tratamentos para os dois períodos experimentais.

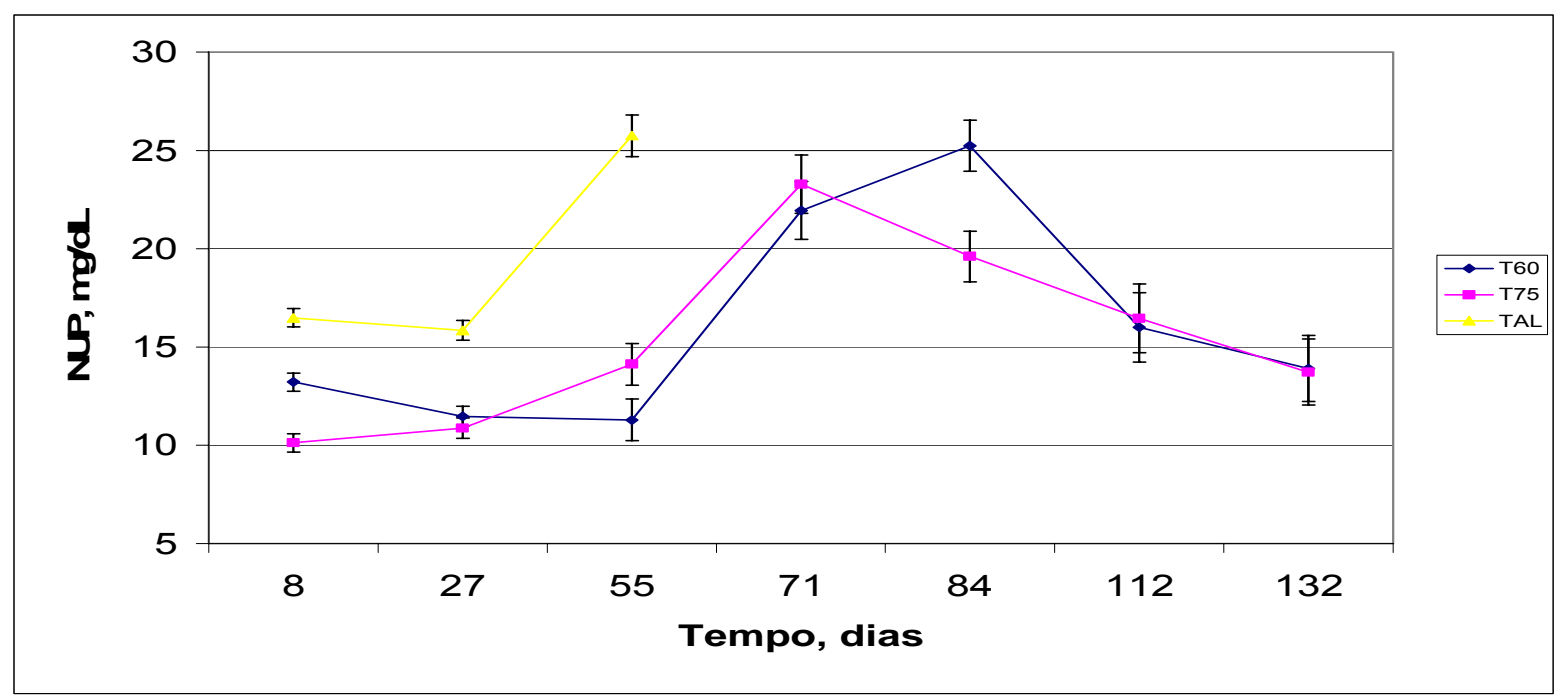

Figura 20 - Concentração de NUP para os tratamentos nos dois Experimentos

No trabalho de Hayden et al. (1993), as concentrações de NUP tiveram comportamento quadrático com menores valores aos 30 dias de realimentação, tanto para o tratamento restrito como para o grupo em compensatório. Estes autores concluíram que durante a realimentação, os metabólitos plasmáticos se alteram rapidamente em favor da promoção do anabolismo de proteína e que as 
concentrações plasmáticas dos hormônios tiroideanos e IGF-I estão intimamente relacionadas com o tipo de tecido corporal ganho em novilhos compensando.

Os valores de nitrogênio uréico no sangue de novilhos observados por Ellenberger et al. (1989) decresceram no início do período de realimentação. Os autores explicam que este fato é indicativo do uso eficiente dos nutrientes no período de realimentação e da maior demanda por nutrientes para o crescimento do tecido visceral.

Segundo Hornick et al. (1998b) o aumento na concentração plasmática de uréia quando os animais entram na fase de realimentação reflete a alta síntese hepática resultante do aumento na produção de amônia microbiana no rúmen ou a maior degradação de aminoácidos no fígado. Este aumento foi observado no dia 71 para os tratamentos T60 eT75 e, também, no dia 84 para o tratamento T60, provavelmente porque teve um ganho compensatório maior.

O balanço de proteína degradável no rúmen para dieta com $80 \%$ de concentrado, usando fonte de proteína verdadeira ou nitrogênio não protéico, foi estudado por Oliveira Jr. et al. (2004). Os valores de N-uréico no plasma sangüíneo de novilhos cruzados Nelore não foram diferentes para as fontes nitrogenadas, mas apresentaram valores, de 17,8 até $20,9 \mathrm{mg} / \mathrm{dL}$, que os autores consideraram elevados.

Em confinamento para terminação de novilhos cruzados Simental Nelore, Mendes et al. (2005) observaram valores próximos de $25 \mathrm{mg} / \mathrm{dL}$ para dietas com $13 \%$ de proteína bruta. Portanto, os valores observados no presente trabalho, tanto na fase de restrição como na realimentação, não saíram dos limites encontrados na literatura.

A exigência de proteína para bovinos zebuínos em confinamento com pesos de 382 a 496 kg de PV encontradas por Obeid et al. (2006) foi de 12\% PB na matéria seca. Portanto, pode-se considerar que a dieta empregada neste experimento $(11,49 \%)$ não esteve acima das quantidades preconizas para estes animais e os valores observados de NUP poderiam estar relacionados aos outros fatores citados anteriormente e não estar vinculado a um possível excesso de proteína na dieta.

Os valores de NUP de 15,8 a 18,9 mg/dL observados por Putrino (2006) não significou suprimento excessivo de proteína bruta aos animais. 
As variações na concentração de glicose e NUP seguiram a mesma tendência para todo o período experimental representando um equilíbrio no metabolismo dos animais. Neste sentido, Fiems et al. (2007) consideraram que existe uma relação entre glicose e proteína, pois concluíram que o aumento no nível de NUP, verificado em experimento de restrição-realimentação de vacas, pode ser devido ao catabolismo de proteína para gliconeogênese, e que a manutenção dos níveis de glicose em período de restrição energética deve-se à necessidade de manutenção dos níveis sangüíneos deste metabólito.

\subsection{Avaliação bioeconômica}

Os dados relativos ao abate e pós-abate estão apresentados na Tabela 24.

Tabela 24 - Médias de peso vivo final, peso de carcaça quente (CQ), rendimento de carcaça quente, peso do fígado e gordura pélvica renal e inguinal (PRI)

\begin{tabular}{|c|c|c|c|c|c|}
\hline \multirow{2}{*}{ Característica } & \multicolumn{3}{|c|}{ Tratamentos } & \multirow{2}{*}{$\mathrm{P}$} & \multirow{2}{*}{ Efeito } \\
\hline & T60 & T75 & TAL & & \\
\hline Peso vivo final, $\mathrm{kg}$ & 476,33 & 489,17 & 439,77 & 0,047 & Quadrático \\
\hline Peso de CQ, kg & 283,17 & 286,89 & 260,94 & 0,023 & Linear \\
\hline Rendimento de CQ, kg & 59,48 & 58,71 & 59,33 & 0,853 & -- \\
\hline Peso do fígado, $\mathrm{kg}$ & 4,87 & 4,79 & 4,87 & 0,995 & -- \\
\hline Gordura PRI, kg & 13,22 & 13,43 & 10,43 & 0,029 & Linear \\
\hline
\end{tabular}

Ao final do período de confinamento para engorda dos animais, que foi de 77 dias para os três tratamentos, os animais do tratamento TAL estavam mais leves devido à diferença de peso inicial dos animais dos tratamentos T60 e T75, que apesar de passarem por 58 dias de alimentação restrita, ganharam peso durante este período. Isto também refletiu no peso da carcaça quente, sem que se alterasse o rendimento de carcaça quente. No trabalho de Hornick et al. (1998a) não houve diferença no rendimento de carcaça para o grupo que passou por um período menor de restrição comparado ao controle.

O peso do fígado não foi diferente entre os tratamentos, mesmo com diferentes períodos de alimentação, sendo 77 dias para o tratamento TAL ou 136 dias para os tratamentos T60 e T75, e com dieta de $80 \%$ de concentrado. Estes dados são discordantes daqueles observados por Drouillard et al. (1991), que 
observaram maior peso do fígado para animais submetidos à restrição energética, quando comparados como porcentagem da carcaça quente.

Já a gordura pélvica, renal e inguinal foi influenciada pelos tratamentos apresentando os maiores valores para os tratamentos T60 e T75, provavelmente em função do maior peso final alcançado por estes animais. O maior acúmulo de gordura em tecidos corporais, que não a carcaça, também foi observado por Carstens et al. (1991).

A avaliação econômica dos efeitos das diferentes velocidades de ganho de peso referentes aos tratamentos por experimento está apresentada na Tabela 25.

Tabela 25 - Custos com matéria seca ingerida (MSI) e reais gastos por quilo de ganho de peso vivo (R\$/kg GPV) e por quilo de carcaça ganho

\begin{tabular}{|c|c|c|c|c|}
\hline \multirow{3}{*}{ Característica } & \multicolumn{3}{|c|}{ Experimento I } & \multirow{3}{*}{$P$} \\
\hline & \multicolumn{3}{|c|}{ Tratamentos } & \\
\hline & T60 & T75 & TAL & \\
\hline Dias de confinamento & 58 & 58 & 58 & -- \\
\hline MSI total, $\mathrm{R} \$$ & 64,93 & 85,24 & 126,86 & -- \\
\hline MSI/DIA, R\$ & 1,12 & 1,47 & 2,19 & -- \\
\hline Ganho em @ & 0,60 & 1,42 & 2,37 & -- \\
\hline $\mathrm{R} \$ / K G$ GPV & 4,10 & 2,30 & 2,00 & $<0,001$ \\
\hline $\mathrm{R} \$ / \mathrm{kg}$ de carcaça ganho & 7,89 & 4,41 & 3,85 & $<0,001$ \\
\hline \multirow{3}{*}{ Característica } & \multicolumn{3}{|c|}{ Experimento II } & \\
\hline & \multicolumn{3}{|c|}{ Tratamentos } & $P$ \\
\hline & T60 & T75 & TAL & \\
\hline Dias de confinamento & 77 & 77 & 77 & -- \\
\hline MSI total, $\mathrm{R} \$$ & 173,53 & 174,75 & 166,10 & -- \\
\hline MSI/DIA, R\$ & 2,25 & 2,27 & 2,13 & -- \\
\hline Ganho em @ & 5,77 & 5,25 & 2,80 & -- \\
\hline $\mathrm{R} \$ / \mathrm{KG} \mathrm{GPV}$ & 1,75 & 2,02 & 1,98 & 0,101 \\
\hline $\mathrm{R} \$ / \mathrm{kg}$ de carcaça ganho & 2,05 & 2,27 & 4,06 & $<0,001$ \\
\hline
\end{tabular}

Nos dados do Experimento I, pode-se observar como a velocidade de ganho de peso pode aumentar o custo de alimentação do confinamento, embora o gasto total com a dieta seja maior para o maior ganho.

Para o Experimento II, que avaliou o ganho de peso compensatório, não houve diferença para o valor em reais gasto por ganho de peso vivo, mas é interessante observar a diferença no valor gasto para a deposição de tecidos na carcaça que foi aproximadamente o dobro para os animais que não estavam em compensação. 
Para que haja melhor eficiência econômica podem ocorrer dois fatores, ou os animais comem a mesma quantidade de alimento e ganham mais peso, como pode ocorrer no ganho de peso compensatório, ou comem uma quantidade menor e ganham o mesmo peso. Esta segunda hipótese foi observada por Gesualdi Júnior et al. (2006) para tourinhos Nelore.

O peso dos animais do tratamento TAL foi elevado para 84 dias, para equiparar os períodos que são de 28 dias, uma vez que estes animais foram abatidos com 77 dias. Fazendo uma projeção dos dados de ganho de peso para os tratamentos em ganho compensatório encontra-se que o tratamento T60 levaria 13 dias para atingir o peso médio do grupo TAL enquanto o tratamento T75 necessitaria de 10 dias. As curvas desta projeção podem ser observadas na Figura 21.

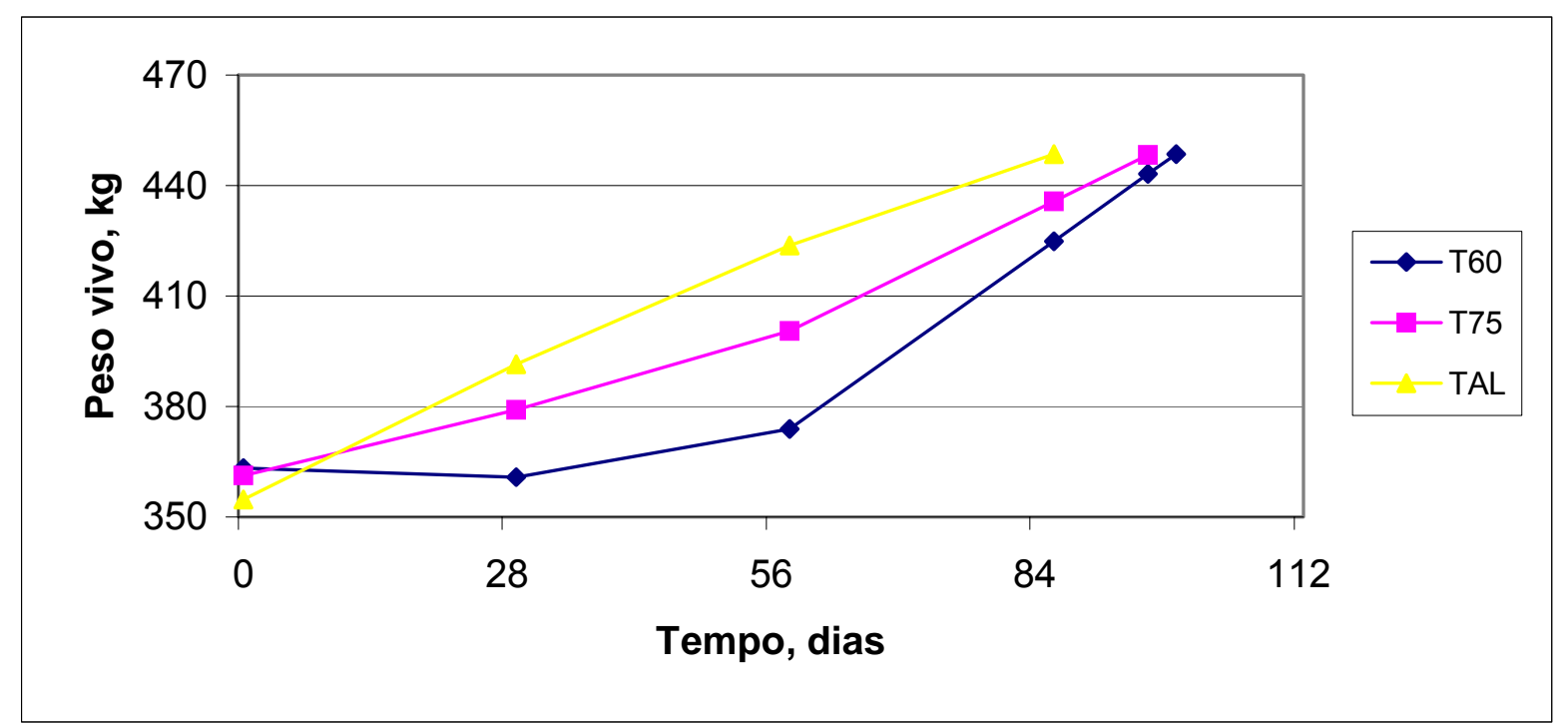

Figura 21 - Projeção das curvas de ganho de peso vivo para os tratamentos em compensação atingirem o peso do tratamento TAL 


\section{Conclusões}

Com base nos dados deste trabalho com novilhos castrados da raça Nelore em regime de confinamento para terminação foi possível concluir que:

A exigência de energia líquida para mantença de Nelore foi de $70 \mathrm{kcal} / \mathrm{PV}^{0,75}$ e a exigência de energia líquida para ganho de peso pode ser obtida pela equação: $\mathrm{EL}_{g}=0,0467$ * $P C V z^{0,75}$ * $\mathrm{GPCV} z^{0,8585}$.

A exigência de proteína líquida para mantença de Nelore foi de $177 \mathrm{~g} / \mathrm{kg}$ PCVz e exigência para ganho de $131 \mathrm{~g} / \mathrm{kg}$ GPCVz. A exigência de proteína metabolizável para mantença foi de $4,32{ }^{*} \mathrm{PV}^{0,75}$ e para ganho de peso foi de 266 g/kg GPCVz ou $270 \mathrm{~g} / \mathrm{kg}$ GPVj.

A restrição alimentar melhorou o desempenho dos animais, pois apresentaram ganho de peso compensatório.

Os parâmetros sangüíneos e o perfil hormonal dos animais foram alterados durante a realimentação favorecendo o metabolismo de proteína e gordura.

O ganho de peso compensatório em confinamento foi $50,5 \%$ mais barato que o ganho de peso normal, quando comparado os animais do tratamento T60 com os animais do tratamento TAL. 


\section{Referências bibliográficas}

ACEDO, T.S. et al. Diferentes fontes protéicas em suplementos múltiplos de baixo consumo para recria de novilhos no período de transição seca-águas e águas. In: REUNIÃO ANUAL DA SOCIEDADE BRASILEIRA DE ZOOTECNIA, 40., 2003, Santa Maria, RS. Anais... Santa Maria: SBZ, 2003. CD - ROM.

ALLEN, D. Planned beef production and marketing. Londres: St. Edmundsbury Press, 1990.

ALLEONI, G.F. et al. Avaliação da composição química e física dos cortes da costela para estimar a composição química corporal de novilhos Nelore. Revista Brasileira de Zootecnia, Viçosa: v.26, n.2, p.382-390, 1997.

BARBOSA, J.D. et al. Estudo comparativo de algumas provas funcionais do fluido ruminal e de metabólitos sangüíneos de bovinos e bubalinos. Pesquisa Veterinária Brasileira, Rio de Janeiro: v.23, n.1, p.33-37, 2003.

BERGMAN, E.N. Distúrbios do metabolismo dos carboidratos e gorduras. In: SWENSON, M.J.; REECE, W.O. ed. Dukes Fisiologia dos Animais Domésticos. $11^{\mathrm{a}}$ Ed. Rio de Janeiro: Guanabara Koogan, 1996. Cap. 27, p.447-456.

BERNDT, A. Composição corporal e exigências líquidas de energia e proteína de tourinhos Santa Gertrudis alimentados com dietas de alto teor de concentrado. 2000. 73f. Dissertação (Mestrado) - Escola Superior de Agricultura Luiz de Queiroz, Universidade de São Paulo, Piracicaba, 2000.

BLUM, J.W. et al. Reduced and compensatory growth: endocrine and metabolic changes during food restriction and refeeding in steers. The Journal of Nutrition, Bethesda: v.115, n.4, p.417-424, 1985.

BOIN, C. Alguns dados sobre exigências de energia e de proteína de zebuínos. In: SIMPÓSIO INTERNACIONAL SOBRE EXIGÊNCIAS NUTRICIONAIS DE RUMINANTES, 1995, Viçosa, MG. Anais... Viçosa: JARD, 1995. p.457-465.

BOIN, C. et al. Tourinhos Nelore em crescimento e acabamento 1. Desempenho e relações entre componentes do ganho. In: REUNIÃO ANUAL DA SOCIEDADE BRASILEIRA DE ZOOTECNIA, 31., 1994, Maringá, PR. Anais... Maringá: SBZ, 1994a, 746p.

BOIN, C. et al. Tourinhos Nelore em crescimento e acabamento 2. Exigências de energia líquida de mantença e eficiência de utilização da energia metabolizável para mantença e crescimento. In: REUNIÃO ANUAL DA SOCIEDADE BRASILEIRA DE ZOOTECNIA, 31., 1994, Maringá, PR. Anais... Maringá: SBZ, 1994b, 746p. 
BOIN, C.; MOURA, M.P. Comparação entre dois níveis de proteína bruta e entre dois níveis de energia para zebuínos em crescimento. Boletim da Indústria Animal, Nova Odessa: v.34, n.2, p.155-163, 1977.

BRITO, R.M. Valor bioeconômico da suplementação alimentar para bovinos em pastagens de Brachiaria brizantha cv. Marandu. 2004. 90 p. Tese (Doutorado) Faculdade de Ciências Agrárias e Veterinárias, Universidade Estadual Paulista "Júlio de Mesquita Filho", Jaboticabal, 2004.

BRODERICK, G.A.; CLAYTON, M.K. A statistical evaluation of animal and nutritional factors influencing concentrations of milk urea nitrogen. Journal of Dairy Science, Lancaster: v.80, n.11, p.2964-2971, 1997.

BULLE, M.L.M. et al. Exigências líquidas de energia e proteína de tourinhos de dois grupos genéticos alimentados com dietas de alto teor de concentrado. Revista Brasileira de Zootecnia, Viçosa: v.31, n.1, p.436-443, 2002 (Suplemento).

BUTTERY, P.J. Hormonal control of protein deposition in animals. Proceedings of the Nutrition Society, Cambridge: v. 42, n.2, p.137-148, 1983.

CABARAUX, J.-F. et al. Variation of plasma parameters and nitrogen metabolism in finishing Belgian Blue double-muscled cull females. Journal of Animal Physiology and Animal Nutrition, München: v.89, p.55-62, 2005.

CALEGARE, L.N.P. Exigências e eficiência energética de vacas de corte Nelore e de cruzamentos Bos taurus x Nelore. 2004. 79f. Dissertação (Mestrado) Escola Superior de Agricultura Luiz de Queiroz, Universidade de São Paulo, Piracicaba, 2004.

CANAVESSI, A.M.O. et al. Valores do perfil eletroforético das proteínas séricas de bovinos da raça Nelore (Bos indicus) criados na região de Botucatu, São Paulo: Influência dos fatores etários e sexuais. Arquivos do Instituto Biológico, São Paulo: v.67, n.1, p.1-11, 2000.

CARSTENS, G.E. et al. Physical and chemical components of the empty body during compensatory growth in beef steers. Journal of Animal Science, Champaign: v.69, N.8, p.3251-3264, 1991.

CHIZZOTTI, M.L. et al. Energy and protein requirements for growth and maintenance of F1 Nellore X Red Angus bulls, steers, and heifers. Journal of Animal Science, Champaign: v.85, n.8, p.1971-1981, 2007.

COLEMAN, M.L. et al. Reduction of Water with Zinc for Hydrogen Isotope Analysis. Analytical Chemistry, Washington: v.54, p.993-995, 1982.

DEVANT, M. et al. Effect of nitrogen source in high-concentrate, low protein beef cattle diets on microbial fermentation studied in vivo and in vitro. Journal of Animal Science, Champaign: v.79, n.7, p.1944-1953, 2001. 
DROUILLARD, J.S. et al. Compensatory growth following metabolizable protein or energy restrictions in beef steers. Journal of Animal Science, Champaign: v.69, n.2, p.811-818, 1991.

EISEMANN, J.; HUNTINGTON, G.; NIENABER, J. Interaction of ractopamine and age on peripheral but not hepatic $\mathrm{N}$ metabolism in beef steers. Journal of Animal Science, Champaign: v.71, Suppl.1, n.171, p.133, 1993.

ELLENBERGER, M.A. et al. Endocrine and metabolic changes during altered growth rates in beef cattle. Journal of Animal Science, Champaign: v.67, n.5, p.1446-1454, 1989.

ESTRADA, L.H.C. et al. Exigências de energia líquida para ganho em animais Nelore e mestiços. In: REUNIÃO ANUAL DA SOCIEDADE BRASILEIRA DE ZOOTECNIA, 31., 1994, Maringá, PR. Anais... Maringá: SBZ, 1994, 746p.

EUCLIDES, V.P.B. et al. Desempenho de novilhos em pastagem de Brachiaria brizantha submetidos a diferentes regimes alimentares. Revista Brasileira de Zootecnia, Viçosa: v.27, n.2, p.246-254, 1998.

FAGLIARI, J.J. et al. Valores de referência das proteínas séricas de bovinos Guzerá em diferentes faixas etárias. Arquivo Brasileiro de Medicina Veterinária e Zootecnia, Belo Horizonte: v.43, n.1, p.39-60, 1991.

FERRELL, C.L.; JENKINS, T.G. Body composition and energy utilization by steers of diverse genotypes fed a high-concentrate diet during the finishing period: II. Angus, Boran, Brahman, Hereford, and Tuli sires. Journal of Animal Science, Champaign: v.76, n.2, p.647-657, 1998.

FIEMS, L.O. et al. Effect of energy restriction and re-alimentation in Belgian Blue double-muscled beef cows on digestibility and metabolites. Journal of Animal Physiology and Animal Nutrition, München: v.91, Issue 1-2, p.54-61, 2007.

FONTES, C.A.A. Composição corporal, exigências líquidas de nutrientes para ganho de peso e desempenho produtivo de animais zebuínos e mestiços europeu-zebu. Resultados experimentais. In: SIMPÓSIO INTERNACIONAL SOBRE EXIGÊNCIAS NUTRICIONAIS DE RUMINANTES, 1995, Viçosa, MG. Anais... Viçosa: JARD, 1995. p.419-455.

FONTES, C.A.A. et al. Conteúdo de energia líquida para mantença e ganho do capim-elefante e mudanças na composição corporal de novilhos em pastejo, durante a estação chuvosa. Revista Brasileira de Zootecnia, Viçosa: v.34, n.5, p.17111720, 2005a.

FONTES, C.A.A. et al. Uso do abate comparativo na determinação da exigência de energia de mantença de gado de corte pastejando capim-elefante: descrição da metodologia e dos resultados. Revista Brasileira de Zootecnia, Viçosa: v.34, n.5, p.1721-1729, 2005b. 
FREITAS, J.A. et al. Exigências de energia para ganho de peso em bovinos (zebuínos e mestiços) e bubalinos. Estudo 1. In: REUNIÃO ANUAL DA SOCIEDADE BRASILEIRA DE ZOOTECNIA, 31., 1994, Maringá, PR. Anais... Maringá: SBZ, 1994a, 746p.

FREITAS, J.A. et al. Composição corporal e do ganho de peso e exigências de proteína para ganho de peso em bovinos (zebuínos e mestiços) e bubalinos. Estudo 2. In: REUNIÃO ANUAL DA SOCIEDADE BRASILEIRA DE ZOOTECNIA, 31., 1994, Maringá, PR. Anais... Maringá: SBZ, 1994b, 746p.

FREITAS, J.A. et al. Composição corporal e exigências de energia de mantença em bovinos Nelore, puros mestiços, em confinamento. Revista Brasileira de Zootecnia, Viçosa: v.35, n.3, p.878-885, $2006 a$.

FREITAS, J.A. et al. Composição do ganho e exigências de energia e proteína para ganho de peso em bovinos Nelore puros e mestiços. Revista Brasileira de Zootecnia, Viçosa: v.35, n.3, p.886-893, 2006b.

FREITAS, J.A. et al. Eficiência de utilização da energia metabolizável em bovinos Nelore puros e cruzados submetidos a quatro níveis de concentrado na ração.

Revista Brasileira de Zootecnia, Viçosa: v.35, n.3, p.894-901, 2006c.

GALATI, R.L. et al. Equações de predição da composição química corporal a partir do corte da 9-10-11 a costelas de bovinos castrados Nelore. Revista Brasileira de Zootecnia, Viçosa: v.36, n.2, p.480-488, 2007.

GARRET, W.N. Factors influencing energetic efficiency of beef production. Journal of Animal Science, Champaign: v.51, n.6, p.1434-1440, 1980.

GEAY, Y. Energy and protein utilization in growing cattle. Journal of Animal Science, Champaign: v.58, n.3, p.766-778, 1984.

GESUALDI JÚNIOR, A. et al. Desempenho produtivo e eficiência bioeconômica de bovinos Nelore e Caracu selecionados para peso aos 378 dias de idade recebendo alimentação à vontade ou restrita. Revista Brasileira de Zootecnia, Viçosa: v.35, n.2, p.576-583, 2006.

GOMES JÚNIOR, P. et al. Desempenho de novilhos mestiços na fase de crescimento suplementados durante a época seca. Revista Brasileira de Zootecnia, Viçosa: v.31, n.1, p.139-147, 2002.

GONÇALVES, L.C. et al. Exigências de energia para cinco grupos genéticos de novilhos. Revista Brasileira de Zootecnia, Viçosa: v.20, n.5, p.421-429, 1991a.

GONÇALVES, L.C. et al. Exigências de proteína para novilhos de cinco grupos genéticos. Revista Brasileira de Zootecnia, Viçosa: v.20, n.5, p.430-437, 1991 b.

GOULART, R.S. Desempenho, características de carcaça, composição corporal e exigências líquidas de crescimento de bovinos Nelore e três cruzamentos Bos taurus 
x Nelore. 2006. 75p. Dissertação (Mestrado) - Escola Superior de Agricultura Luiz de Queiroz, Universidade de São Paulo, Piracicaba, 2006.

HAYDEN, J.M.; WILLIAMS, J.E.; COLLIER, R.J. Plasma growth hormone, insulin-like growth factor, insulin, and thyroid hormone association with body protein and fat accretion in steers undergoing compensatory gain after dietary energy restriction. Journal of Animal Science, Champaign: v.71, n.12, p.3327-3338, 1993.

HENRIQUE, W. et al. Estimativa da composição química corporal de tourinhos Santa

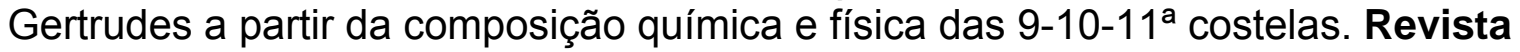
Brasileira de Zootecnia, Viçosa: v.32, n.3, p.709-718, 2003.

HERSOM, M.J.W. et al. Effect of the live weight gain of steers during winter grazing on digestibily, acid-base balance, blood flow, and oxygen consumption by splanchnic tissues during adaptation and subsequent feeding of a high-grain diet. Journal of Animal Science, Champaign: v.81, n.12, p.3130-3140, 2003.

HORNICK, J.L. et al. Different periods of feed restriction before compensatory growth in Belgian Blue bulls: I. Animal performance, nitrogen balance, meat characteristics, and fat composition. Journal of Animal Science, Champaign: v.76, n.1, p.249-259, 1998.

HORNICK, J.L. et al. Different periods of feed restriction before compensatory growth in Belgian Blue bulls: II. Plasma metabolites and hormones. Journal of Animal Science, Champaign: v.76, n.1, p.260-271, 1998.

HUNTINGTON, G.; ARCHIBEC, S.L. Practical aspects of urea and ammonia metabolism in ruminants. Proceedings of the American Society of Animal Science, 1999. Disponível em: <http://www.asas.org/jas/symposia/proceedings/0939.pdf>. Acesso em: 01/02/2007.

HUNTINGTON, G.B. et al. Effects of dietary concentrate level on nutrient absorption, liver metabolism, and urea kinetcs of beef steers fed isonitrogenous and isoenergetc diets. Journal of Animal Science, Champaign: v.74, n.9, p.908-916, 1996.

HUNTINGTON, G. et al. Effect of protein degradability on growth and N metabolism in growing beef steers. Journal of Animal Science, Champaign: v.79, n.2, p.533541, 2001.

JORGE, A.M. et al. Utilização de método indireto para predição da composição química corporal de zebuínos. Revista Brasileira de Zootecnia, Viçosa: v.29, n.6, p.1862-1867, 2000.

KLOPFENSTEIN, T. et al. Effects of backgrounding and growing programs on beef carcass quality and yield. Proceedings of the American Society of Animal Science, 1999. Disponível em: <http://www.asas.org/jas/symposia/proceedings/0942.pdf>. Acesso em: 01/02/2007.

LANNA, D.P.D. et al. Desempenho e composição corporal de novilhas alimentadas com dois níveis de concentrado e bagaço de cana submetidos a diferentes 
processos de hidrólise. Revista Brasileira de Zootecnia, Viçosa: v.28, n.2, p.412420, 1998.

LEEK, B.F. Digestão no estômago dos ruminantes. In: SWENSON, M.J.; REECE, W.O. ed. Dukes Fisiologia dos Animais Domésticos. $11^{\text {a }}$ Ed. Rio de Janeiro: Guanabara Koogan, 1996. Cap. 21, p.353-379.

LEHNINGER, A.L. Lehninger Princícpios de Bioquímica / Nelson, D.L. e COX, M.M. $3^{a}$ ed. São Paulo: Sarvier, 2002. Traduzido por SIMÕES, A.A. e LODI, W.R.N., $975 p$.

LEME, P.R. Estimativa da composição química corporal de novilhos Nelore através do espaço de deutério. 1993. 78f. Tese (Doutorado) - Faculdade de Ciências Agrárias e Veterinárias, Universidade Estadual Paulista "Júlio de Mesquita Filho", Jaboticabal, 1993.

LEME, P.R. et al. Estimativa da composição corporal de novilhos Nelore através do espaço de deutério. Revista Brasileira de Zootecnia, Viçosa: v.23, n.3, p.441-452, 1994.

LEME, P.R. et al. Substituição do grão de milho por polpa de citros em dietas com diferentes níveis de concentrado. 2. Taxas de deposição e composição química corporal. Revista Brasileira de Zootecnia, Viçosa: v.29, n.3, p.834-839, 2000.

LIMA, A.S. Avaliação do perfil hormonal de garrotes submetidos à carência energética prolongada. 2005. 139f. Dissertação (Mestrado) - Faculdade de Medicina Veterinária e Zootecnia, Universidade de São Paulo, São Paulo, 2005.

LIMA, M.L.P. et al. Concentração de nitrogênio uréico plasmático (NUP) e produção de leite de vacas mestiças em gramíneas tropicais sob pastejo rotacionado. Revista Brasileira de Zootecnia, Viçosa: v.33, n.6, p.1616-1626, 2004.

LOFGREEN, G.P.; GARRETT, W.N. A system for expressing net energy requirements and feed values for growing and finishing beef cattle. Journal of Animal Science, Champaign: v.27, n.3, p.793-806, 1968.

LUCA, G.C.; REIS, B.F. Espectrofotometria de proteínas totais em plasma de sangue bovino por análise em fluxo. Scientia Agrícola, Piracicaba: v.59, n.2, p.251256, 2001.

MANELLA, M.Q. Curso On line: Suplementação protéica - energética de bovinos corte a pasto. Módulo 1 - Introdução e aspectos gerais da produção e suplementação animal a pasto. 2003. 9 p. /Apostila/.

MANELLA, M.Q.; LOURENÇO, A.J.; LEME, P.R. Recria de bovinos Nelore em pastos de Brachiaria brizantha com suplementação protéica ou com acesso a banco de proteína de Leucaena lecocephala. Desempenho animal. Revista Brasileira de Zootecnia, Viçosa: v.31, n.6, p.2274-2282, 2002. 
McDOWELL, G.H. Hormonal control of glucose homoestasis in ruminants. Proceedings of the Nutrition Society. Cambridge: v. 42, n.2, p.149-167, 1983.

McFARLAND, D. Animal Behaviour: psychobiology, ethology and evolution. 3rd ed. Harlow, England: Longman, 1999.

MENDES, A.R. et al. Desempenho, parâmetros plasmáticos e características de carcaça de novilhos alimentados com farelo de girassol e diferentes fontes energéticas, em confinamento. Revista Brasileira de Zootecnia, Viçosa: v.34, n.2, p.692-702, 2005.

NKRUMAH, J.D. et al. Relationships of feedlot feed efficiency, performance, and feeding behavior with metabolic rate, methane production, and energy partitioning in beef cattle. Journal of Animal Science, Champaign: v.84, n.1, p.145-153, 2006.

NRC - NATIONAL RESEARCH COUNCIL. Nutrient requirements of beef cattle, 7 ed. Washington: National Academy Press, 1996. 242p.

NRC - NATIONAL RESEARCH COUNCIL. Nutrient requirements of beef cattle, Rev. ed. Washington: National Academy Press, 1984. 102p.

OBEID, J.A. et al. Níveis de proteína bruta em dietas para bovinos de corte: consumo, digestibilidade e desempenho produtivo. Revista Brasileira de Zootecnia, Viçosa: v.35, n.6, p.2434-2442, 2006.

O'DONOVAN, P.B. Compensatory gain in cattle and sheep. Nutrition Abstracts and Reviews - Series B, Famham Royal: v.54, n.8, p.389-410, 1984.

OLIVEIRA JUNIOR, R.C. et al. Substituição total do farelo de soja por uréia ou amiréia, em dietas com alto teor de concentrado, sobre a amônia ruminal, os parâmetros sangüíneos e o metabolismo do nitrogênio em bovinos de corte. Revista Brasileira de Zootecnia, Viçosa: v.33, n.3, p.738-748, 2004.

OWENS, F.N.; DUBESKI, P.; HANSON, C.F. Factors that alter the growth and development of ruminants. Journal of Animal Science, Champaign: v.71, n.11, p.3138-3150, 1993.

PAULINO, M.F. et al. Efeito de níveis de uréia em suplementos múltiplos sobre o desempenho de bovinos sob pastejo no período de transição águas/seca. In: REUNIÃO ANUAL DA SOCIEDADE BRASILEIRA DE ZOOTECNIA, 41., 2004, Campo Grande, MS. Anais... Campo Grande: SBZ, 2004a. CD-ROM.

PAULINO, P.V.R. et al. Exigências nutricionais de zebuínos: Proteína. Revista Brasileira de Zootecnia, Viçosa: v.33, n.3, p.759-769, 2004b.

PAULINO, P.V.R. et al. Validação das equações desenvolvidas por Hankins e Howe para predição da composição da carcaça de zebuínos e desenvolvimento de equações para estimativa da composição corporal. Revista Brasileira de Zootecnia, Viçosa: v.34, n.1, p.327-339, 2005. 
PAULINO, P.V.R. et al. Predição da composição química corporal e da carcaça de

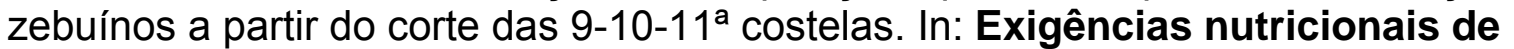
zebuínos e tabelas de composição de alimentos BR-Corte. Editores: VALADARES FILHO, S.de C.; PAULINO, P.R.; MAGALHÃES, K.A. 1.ed. Viçosa: UFV, DZO, 2006, 142p.

PEREIRA, A.S.C.; AFERRI, G. Ganho de peso compensatório: há problemas com a qualidade da carne de bovinos? 2006. Disponível em:

<http://www.beefpoint.com.br/pop/noticia.asp?notícialD=28769\&secaolD=179>. Acesso em: 09/01/2007.

PUTRINO, S.M. Exigências de proteína e energia líquidas para o ganho de peso de tourinhos das raças Nelore e Brangus alimentados com dietas com diferentes proporções de concentrado. 2002. 82f. Dissertação (Mestrado) Faculdade de Zootecnia e Engenharia de Alimentos, Universidade de São Paulo, Pirassununga, 2002.

PUTRINO, S.M. et al. Exigências líquidas de proteína e energia para ganho de peso de tourinhos Brangus e Nelore alimentados com dietas contendo diferentes proporções de concentrado. Revista Brasileira de Zootecnia, Viçosa: v.35, n.1, p.292-300, 2006.

REECE, W.O. Fisiologia de animais domésticos. Tradução de Nelson Penteado Junior. São Paulo: Roca, 1996.

REID, J.T. et al. Body water estimation in relation to body composition and indirect calorimetry in ruminants. Animal Academy Science, New York: v.110, n.2, p.327342, 1963.

REID, J.T.; WELLINGTON, G.H.; DUNN, H.O. Some relationships among the major chemical components of the bovine body and their application to nutritional investigation. Journal of Dairy Science, Champaign: v.38, n.12, p.1344-1359, 1955.

RIBEIRO, A.R.B. et al. Avaliação das respostas fisiológicas de bezerros zebuínos puros e cruzados nascidos em clima subtropical. Revista Brasileira de Zootecnia, Viçosa: v.35, n.3, p.1146-1153, 2006 (Suplemento).

RUSSELL, J.B. Strategies that ruminal bacteria use to handle excess carbohydrate. Journal of Animal Science, Champaign: v.76, n.7, p.1955-1963, 1998.

RUSSELL, J.B.; COOK, G.M. Energetics of bacterial growth: balance of anabolic and catabolic reactions. Microbiological Reviews, Washington: v.59, n.1, p.48-62, 1995.

RYAN, W.J. Compensatory growth in cattle and sheep. Nutrition Abstracts and Reviews (Series B), Aberdeen: v.60, n.9, p.653-664, 1990.

SAINZ, R.D.; DE LA TORRE, F.; OLTJEN, J.W. Compensatory growth and carcass quality in growth-restricted and refed beef steers. Journal of Animal Science, Champaign: v.73, n.10, p.2971-2979, 1995. 
SALES, M.F.L. et al. Desempenho de novilhos recriados em pastagens de "Brachiaria decumbens" suplementados com diferentes fontes de proteína durante o período seco. . In: REUNIÃO ANUAL DA SOCIEDADE BRASILEIRA DE ZOOTECNIA, 41., 2004, Campo Grande, MS. Anais... Campo Grande: SBZ, 2004. CD-ROM.

SAS I Start user's guide version 6. 4. Ed. Cary, North Carolina. SAS Institute Inc., 1989.

SCAGLIUSI, F.B.; LANCHA JÚNIOR, A.H. Estudo do gasto energético por meio da água duplamente marcada: fundamentos, utilização e aplicações. Revista de nutrição, Campinas: v.18, n.4, p.541-551, 2005.

SCANES, C.G. Biology of growth of domestic animals. Ames: lowa State Press, 2003.

SCOT CONSULTORIA, Informativo Pecuário Semanal - Boi \& Companhia, Bebedouro: n.668, p.11-13, 2006.

SHAIN, D.H. et al. Effect of degradable intake protein level on finishing cattle performance and ruminal metabolism. Journal of Animal Science, Champaign: v.76, n.1, p.242-248, 1998.

SILVA, D.J.; QUEIROZ, A.C. Análise de Alimentos: Métodos químicos e biológicos. 3 ed. Viçosa: UFV, 2002. 235p.

SILVA, F.F. et al. Exigências líquidas e dietéticas de energia, proteína e macroelementos minerais de bovinos de corte no Brasil. Revista Brasileira de Zootecnia, Viçosa: v.31, n.2, p.776-792, 2002a.

SILVA, F.F. et al. Composição corporal e requisitos energéticos e protéicos de bovinos Nelore, não-castrados, alimentados com rações contendo diferentes níveis de concentrado e proteína. Revista Brasileira de Zootecnia, Viçosa: v.31, n.1, p.503-513, 2002b (Suplemento).

SUSMEL, P. et al. N losses, purine $\mathrm{N}$ derivates excretion and intestinal digestible protein requirements of cows at maintenance. Livestock Production Science, Amsterdam: v.36, p.213-222, 1993.

SWENSON, M.J. Propriedades fisiológicas e componentes químicos e celulares do sangue. In: SWENSON, M.J.; REECE, W.O. ed. Dukes Fisiologia dos Animais Domésticos. 11ª Ed. Rio de Janeiro: Guanabara Koogan, 1996. Cap.3, p.19-43.

TEDESCHI, L.O.; FOX, D.G.; RUSSELL, J.B. Accounting for the effects of a ruminal nitrogen within the structure of the Cornell Net Carbohydrate and Protein System. Journal of Animal Science, Champaign: v.78, n.6, p.1648-1658, 2000.

TEDESCHI, L.O. et al. Energy requirement for maintenance and growth of Nellore bulls and steers fed high-forage diets. Journal of Animal Science, Champaign: v.80, n.6, p.1671-1682, 2002. 
TOLLA, N.; MIRKENA, T.; YIMEGNUHAL, A. Effect of feed restrition on compensatory growth of Arsi (Bos indicus) bulls. Animal Feed Science and Technology, Amsterdam: v.103, p.29-39, 2003.

TOMICH, T.R. et al. Desempenho animal e retorno econômico determinado pela suplementação de bezerros com diferentes formulações de misturas múltiplas. In: REUNIÃO ANUAL DA SOCIEDADE BRASILEIRA DE ZOOTECNIA, 40., 2003, Santa Maria, RS. Anais... Santa Maria: SBZ, 2003. CD-ROM.

VALADARES, R.F.D. et al. Níveis de proteína em dietas de bovinos. 2. Consumo, digestibilidade e balanço de compostos nitrogenados. Revista Brasileira de Zootecnia, Viçosa: v.26, n.6, p.1259-1263, 1997.

VALADARES FILHO, S.C.; PAULINO, P.V.R.; SAINZ, R.D. Desafios metodológicos para determinação das exigências nutricionais de bovinos de corte no Brasil. In: REUNIÃO ANUAL DA SOCIEDADE BRASILEIRA DE ZOOTECNIA, 42., 2005, Goiânia, GO. Anais... Goiânia: SBZ: Universidade Federal de Goiás, 2005. p.261287.

VALADARES FILHO, S.C.; PAULINO; P.V.R.; MAGALHÃES, K.A. Exigências nutricionais de zebuínos e tabelas de composição de alimentos BR-Corte.1.ed. Viçosa: UFV, 2006, 142p.

VAZ, N.F. et al. Ganho de peso antes e após os sete meses no desenvolvimento e características quantitativas da carcaça de novilhos Nelore abatidos aos dois anos. Revista Brasileira de Zootecnia, Viçosa: v.33, n.4, p.1029-1038, 2004.

VÉRAS, A.S.C. et al. Predição da composição química corporal de bovinos Nelore e F1 Simental x Nelore a partir da composição química da seção Hankins e Howe (Seção HH). Revista Brasileira de Zootecnia, Viçosa: v.30, n.3, p.1112-1119, 2001a (Suplemento 1).

VÉRAS, A.S.C. et al. Predição da composição corporal e dos requisitos de energia e proteína para ganho de peso de bovinos, não-castrados, alimentados com rações contendo diferentes níveis de concentrado. Revista Brasileira de Zootecnia, Viçosa: v.30, n.3, p.1127-1134, 2001b (Suplemento 1).

ZEOULA, L.M. et al. Recuperação fecal de indicadores internos avaliados em ruminantes. Revista Brasileira de Zootecnia, Viçosa: v.31, n.4, p.1865-1874, 2002.

WILKERSON, V.A. et al. Metabolizable protein and amino acid requirements of growing cattle. Journal of Animal Science, Champaign: v.71, p.2777-2784, 1993.

WILLIAMS, C.B.; JENKINS T.G. A dynamic model of metabolizable energy utilization in growing and mature cattle. III. Model evaluation. Journal of Animal Science, Champaign: v.81, n.6, p.1390-1398, 2003. 
WEBSTER, A.J.F. Energetics of Maintence and Growth. In: GIRARDIER, L.; STOCK, M.J. ed. Mammalian Thermo genesis. London/New York: Chapman and Hall, 1983. p.178-207.

WEEKES, T.E.C. The hormonal control of fat metabolism in animals. Proceedings of the Nutrition Society, Cambridge: v. 42, p.129-136, 1983.

WRIGHT, I.A.; RUSSEL, A.J.F. Changes in the body composition of beef cattle during compensatory growth. Animal Production, v.52, n.1 p.105-113, 1991. 